\title{
AHURi ${ }_{\text {australian Housing }}^{\text {arban Research Institute }}$
}
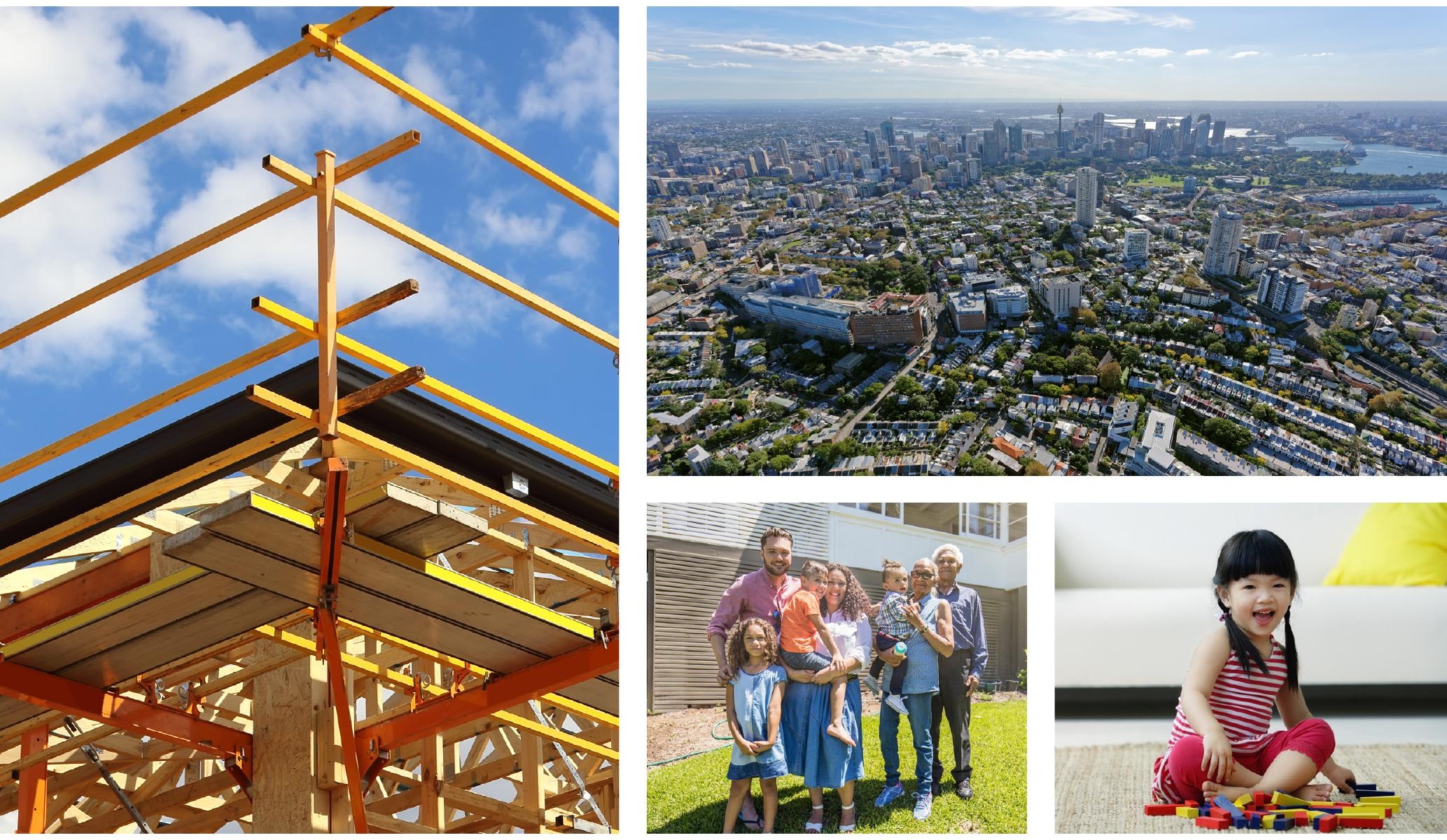

FINAL INQUIRY REPORT

\section{Pathways to housing tax reform}

FOR THE

Australian Housing

and Urban Research Institute

PUBLICATION DATE

July 2018

DOI

10.18408/ahuri-4111001

AUTHORED BY

\section{Richard Eccleston}

University of Tasmania

Julia Verdouw

University of Tasmania

\section{Kathleen Flanagan}

University of Tasmania

Neil Warren

The University of New South Wales

Alan Duncan

Curtin University
Rachel Ong

Curtin University

\section{Stephen Whelan}

University of Sydney

\section{Kadir Atalay}

University of Sydney 


\begin{tabular}{lll} 
Title & Pathways to housing tax reform & \\
\hline Authors & Richard Eccleston & University of Tasmania \\
& Julia Verdouw & University of Tasmania \\
& Kathleen Flanagan & University of Tasmania \\
& Neil Warren & The University of New South Wales \\
& Alan Duncan & Curtin University \\
& Rachel Ong & Curtin University \\
& Stephen Whelan & University of Sydney \\
& Kadir Atalay & University of Sydney \\
\hline ISBN & $978-1-925334-65-4$ &
\end{tabular}

Australian states and territories, housing tax policy design, tax reform, housing Key words affordability, investor, home owner, retiree, taxpayer, modelling, stakeholder consultation.

\begin{tabular}{|c|c|c|c|c|c|}
\hline Series & AHURI Final Report & Number & 301 & ISSN & $1834-7223$ \\
\hline Publisher & \multicolumn{5}{|c|}{$\begin{array}{l}\text { Australian Housing and Urban Research Institute Limited } \\
\text { Melbourne, Australia }\end{array}$} \\
\hline DOI & \multicolumn{5}{|c|}{ 10.18408/ahuri-4111001 } \\
\hline Format & \multicolumn{5}{|l|}{ PDF, online only } \\
\hline URL & \multicolumn{5}{|c|}{ http://www.ahuri.edu.au/research/final-reports/301 } \\
\hline
\end{tabular}

\section{Recommended citation}

Eccleston, R., Verdouw, J., Flanagan, K., Warren, N., Duncan, A., Ong, R., Whelan, S. and Atalay, K. (2018) Pathways to housing tax reform, AHURI Final Report No. 301, Australian Housing and Urban Research Institute Limited, Melbourne, http://www.ahuri.edu.au/research/final-reports/301, doi: 10.18408/ahuri-4111001.

\section{Related reports and documents}

Eccleston, R., Warren, N., Verdouw, J. and Flanagan, K. (2017) Pathways to state property tax reform, AHURI Final Report No. 291, Australian Housing and Urban Research Institute Limited, Melbourne, https://www.ahuri.edu.au/research/final-reports/291, doi:10.18408/ahuri-4111301.

Duncan, A.S., Hodgson, H., Minas, J., Ong-Viforj, R. and Seymour, R. (2018) The income tax treatment of housing assets: an assessment of proposed reform arrangements, AHURI Final Report No. 295, Australian Housing and Urban Research Institute Limited, Melbourne, https://www.ahuri.edu.au/research/final-reports/295, doi:10.18408/ahuri8111101. 
Whelan, S., Atalay, K., Dynan, L. (2018) Asset portfolio retirement decisions: the role of the tax and transfer system, AHURI Final Report No. 298, Australian Housing and Urban Research Institute Limited, Melbourne, https://www.ahuri.edu.au/research/final-reports/298, doi:10.18408/ahuri-7311201.

\section{Inquiry panel members}

Each AHURI Inquiry is supported by a panel of experts drawn from the research, policy and practice communities.

The Inquiry Panel are to provide guidance on ways to maximize the policy relevance of the research and draw together the research findings to address the key policy implications of the research. Panel members for this Inquiry:

Peter Davidson

Karen Doran

Saul Eslake

Glen Hepburn

Brian Howe AO

Caryn Kakas

Paul McBride

Greg Smith

Peter White
Australian Council of Social Services

ACT Treasury

University of Tasmania

Department of Treasury and Finance, Victorian Government

University of Melbourne

Department of Family and Community Services, NSW Government

Department of Social Services, Australian Government

University of Melbourne Law School

Department of Health and Human Services, Tasmanian Government 


\section{AHURI}

AHURI is a national independent research network with an expert not-for-profit research management company, AHURI Limited, at its centre.

AHURI's mission is to deliver high quality research that influences policy development and practice change to improve the housing and urban environments of all Australians.

Using high quality, independent evidence and through active, managed engagement, AHURI works to inform the policies and practices of governments and the housing and urban development industries, and stimulate debate in the broader Australian community.

AHURI undertakes evidence-based policy development on a range of priority policy topics that are of interest to our audience groups, including housing and labour markets, urban growth and renewal, planning and infrastructure development, housing supply and affordability, homelessness, economic productivity, and social cohesion and wellbeing.

\section{Acknowledgements}

This material was produced with funding from the Australian Government and state and territory governments. AHURI Limited gratefully acknowledges the financial and other support it has received from these governments, without which this work would not have been possible.

AHURI Limited also gratefully acknowledges the contributions, both financial and in-kind, of its university research partners who have helped make the completion of this material possible.

The authors would like to thank Tim Lawless, Research Director, Asia Pacific, CoreLogic, for providing access to their data.

\section{Disclaimer}

The opinions in this report reflect the views of the authors and do not necessarily reflect those of AHURI Limited, its Board, its funding organisations or Inquiry panel members. No responsibility is accepted by AHURI Limited, its Board or funders for the accuracy or omission of any statement, opinion, advice or information in this publication.

\section{AHURI journal}

AHURI Final Report journal series is a refereed series presenting the results of original research to a diverse readership of policy-makers, researchers and practitioners.

\section{Peer review statement}

An objective assessment of reports published in the AHURI journal series by carefully selected experts in the field ensures that material published is of the highest quality. The AHURI journal series employs a double-blind peer review of the full report, where anonymity is strictly observed between authors and referees.

\section{Copyright}

(c) Australian Housing and Urban Research Institute Limited 2018

This work is licensed under a Creative Commons Attribution-NonCommercial 4.0 International License, see http://creativecommons.org/licenses/by-nc/4.0/. 


\section{Contents}

List of tables

List of figures vii

Acronyms and abbreviations used in this report viii

Glossary viii

Executive summary 1

Key points 1

Key findings 1

Policy development options 3

$\begin{array}{ll}\text { The study } & 6\end{array}$

1 Introduction: housing tax in Australia $\quad 7$

1.1 Why this research was conducted 7

1.1.1 The problem: housing $\quad 7$

$\begin{array}{ll}\text { 1.1.2 The problem: tax reform } & 10\end{array}$

1.2 Housing and tax policy reform in Australia 11

1.2.1 The tax treatment of property in Australia 11

1.2.2 What we already know 12

$\begin{array}{ll}\text { 1.2.3 Policy, practice and debate } & 13\end{array}$

$\begin{array}{lll}\text { 1.2.4 The recent reform agenda } & 13\end{array}$

$\begin{array}{lll}1.2 .5 & \text { Reform politics } & 14\end{array}$

$\begin{array}{lll}1.3 & \text { Designing the pathway to reform } & 17\end{array}$

$\begin{array}{lll}\text { 1.3.1 A strategy for change } & 17\end{array}$

$\begin{array}{ll}\text { 1.3.2 The what and the how of change } & 17\end{array}$

1.4 Research methods 19

$2 \quad$ Income tax and housing 21

$2.1 \quad$ The policy challenge 22

2.2 Reform alternatives 24

2.3 Key findings 25

2.3.1 Existing policies: who benefits? 25

2.3.2 Reforming negative gearing: a deduction cap 26

2.3.3 Reforming capital gains tax: reducing the discount 27

$\begin{array}{lll}2.4 & \text { Implications and recommendations } & 29\end{array}$

$\begin{array}{lll}2.4 .1 & \text { Recommendations } & 30\end{array}$

$3 \quad$ Housing in retirement 31 
3.1 The policy challenge 32

3.2 Reform alternatives 33

3.3 Key findings 35

3.3.1 Do households structure their asset portfolios to maximise access to the age pension? $\quad 35$

3.3.2 Did the abolition of the superannuation surcharge change households' behaviour? 36

3.3.3 Did changes to the age pension taper rate change households' $\begin{array}{ll}\text { behaviour? } & 37\end{array}$

3.4 Implications and recommendations 38

$\begin{array}{lll}3.4 .1 & \text { Recommendations } & 39\end{array}$

4 State property tax reform $\quad \mathbf{4 0}$

$\begin{array}{lll}4.1 & \text { The policy challenge } & 41\end{array}$

$\begin{array}{lll}4.2 & \text { Reform alternatives } & 42\end{array}$

$4.3 \quad$ Key findings 43

4.3.1 The foundations of reform: property tax administration 43

4.3.2 Simplifying transfer duty design 44

4.3.3 Changing the mix: transfer duty and recurrent property tax 48

$\begin{array}{lll}4.4 & \text { Implications and recommendations } & 49\end{array}$

4.4.1 Recommendations: $\quad 49$

$5 \quad$ Pathways to housing tax reform 51

5.1 Designing the pathway 51

5.2 Directing the pathway 55

5.2.1 Do these reforms work as an 'integrated package'? 55

$\begin{array}{ll}5.3 & \text { Overcoming the barriers } \\ & 58\end{array}$

5.3.1 Minimising distributional impacts $\quad 59$

$\begin{array}{ll}\text { 5.3.2 Minimising market disruption } & 60\end{array}$

$\begin{array}{lll}\text { 5.3.3 Preserving state government revenue } & 60\end{array}$

$\begin{array}{lll}\text { 5.3.4 Coordinating change across the federation } & 61\end{array}$

$\begin{array}{lll}5.4 & \text { Limiting factors } & 61\end{array}$

$\begin{array}{lll}5.5 & \text { Concluding remarks } & 62\end{array}$

References $\quad 63$

$\begin{array}{ll}\text { Appendix } & 73\end{array}$ 


\section{List of tables}

Table 1: Inquiry and supporting projects: summary of methods and scope 20

Table 2: Mean tax savings due to rental deduction caps, 2013-14 figures 26

Table 3: Age pension asset test thresholds 32

Table 4: Mean changes in wealth allocations to different categories of assets, 20022014: comparison of groups affected and unaffected by 2007 change to age pension taper rate

Table 5: Thresholds (\$ value and percentage of median house price) required to achieve revenue neutrality at different rates of transfer duty

Table 6: Required rate of recurrent property tax (paid on value above threshold) to reduce transfer duty rate from $6 \%$ to $3 \%$ and indicative annual payments for both, all states

Table 7: Summary of expected reform outcomes

Table 8: Summary of major party policy announcements in the lead-up to the 2016 federal election 


\section{List of figures}

Figure 1: Home ownership rates by age and income, 1981 and 2016

Figure 2: Housing tax policy, expenditure and regulation in Australian federation. 10

Figure 3: Pathways to housing tax reform: Inquiry conceptual framework 18

Figure 4: Percentage and number of property investors who are negatively geared, 1993-94 to 2013-14

Figure 5: Distributional impacts of rental deduction cap reforms, 2013-14 figures 27

Figure 6: Impact of reduction in CGT on a $\$ 105,000$ capital gain under different levels of CGT discount: average and high income investors compared

Figure 7: Mean percentage of before-tax salary contributed to superannuation 20022014: comparison of groups fully affected and unaffected by 2005 abolition of superannuation surcharge

Figure 8: A pathway to state property tax reform

Figure 9: Thresholds and 'break even' points (percentage of purchasers paying less and maximum property value below which purchasers would pay less) under the new regime

Figure 10: An integrated reform pathway 


\section{Acronyms and abbreviations used in this report}

$\begin{array}{ll}\text { AHURI } & \text { Australian Housing and Urban Research Institute Limited } \\ \text { ALP } & \text { Australian Labor Party } \\ \text { ATO } & \text { Australian Tax Office } \\ \text { CGT } & \text { Capital Gains Tax } \\ \text { CIV } & \text { Capital Improved Value } \\ \text { GFC } & \text { Global Financial Crisis } \\ \text { GST } & \text { Goods and Services Tax } \\ \text { HBU } & \text { Highest and Best Use } \\ \text { HILDA } & \text { Household, Income and Labour Dynamics in Australia }\end{array}$

\section{Glossary}

A list of definitions for terms commonly used by AHURI is available on the AHURI website www.ahuri.edu.au/research/glossary. 


\section{Executive summary}

\section{Key points}

- Lack of access to and secure tenure within affordable housing are significant problems in Australia. Local, state and national taxes currently applied to housing contribute to these poor outcomes.

- There is a consensus that coordinated, well-designed reforms to the treatment of housing in the tax and transfer system can make a significant contribution to improving housing outcomes. However, the prospects of achieving significant reform are diminished by formidable political barriers.

- The Inquiry proposes a housing tax reform pathway informed by a political economy approach that seeks to balance technical reform objectives with political imperatives. The pathway is organised into sequential phases over a 1015 year timeframe. When implemented, reforms will contribute to enhancing residential mobility, improving housing accessibility and affordability, reducing incentives for short-term investment in residential property, and improving rental supply and security.

- The pathway would proceed as follows:

— establish the conceptual and administrative foundations for a national reform agenda while building community consensus around the broader objectives of reform

— develop and implement new policy frameworks with settings designed to minimise the impact on government budgets and housing markets

— incrementally modify policy settings to shift tax distribution to owners of high value properties to improve access and affordability in the Australian housing market.

\section{Key findings}

Despite a sustained period of economic growth in Australia, housing affordability and accessibility have declined significantly in recent years. The resulting shortage of suitable, affordable housing is having an adverse effect on the housing needs and aspirations of many Australians and represents a growing risk to the Australian economy.

There is increasing evidence that tax policy settings are contributing to the problem, exacerbating intergenerational inequality, inflated housing prices and reduced mobility. In recent years there has been no shortage of credible proposals for change, most notably the comprehensive and integrated agenda set out by the Henry review (Henry, Harmer et al. 2009).

Although there is no uniform agreement on how best to progress them, there is considerable academic and policy consensus that a range of tax-related reforms can and should be made to promote housing affordability. But despite the consensus, reforms to date have been piecemeal and ineffective, and attempts at forging a national reform program, such as the 'Re:Think' consultation process (see Australian Government 2015), have had limited follow-through. Again, there is general agreement on the reasons for this: that it is due to the influence of entrenched 
commercial interests on the political process, as well as the difficulties of coordinating reform across the federation and perceptions that policy change in this area will produce significant electoral backlash and therefore represents an untenable political risk.

This Inquiry sets out to respond to the following research question:

What are the best integrated housing tax reform pathways that are financially sustainable, politically viable, and address tax-related distortions in Australian housing markets?

Drawing on the findings (see below) of three connected empirical research projects, we propose in this Inquiry Final Report a coordinated, staged program of housing tax reforms.

These are designed to have minimal immediate impact on government or household budgets but will, over time, gradually shift the distribution of property taxes so that owners of higher value properties are paying proportionally more. The proposals, if implemented, will improve access and affordability in Australia's housing system while enhancing the efficiency of the national economy.

It was beyond the scope of any of the empirical projects or of this overarching Inquiry to conduct detailed modelling of the cumulative impact of the proposed reforms. However, the program is purposefully designed to allow for adaptation over time should the cumulative consequences prove problematic or external economic conditions change radically. The reforms also include measures to ensure that asset rich yet income poor households are not adversely affected. Additional revenue raised through the gradual reduction of income tax concessions available to property owners and investors should be invested in new social housing and rental supply.

Table: Key findings by empirical research project

\begin{tabular}{|c|c|c|}
\hline $\begin{array}{l}\text { Project: Income tax } \\
\text { treatment of housing assets }\end{array}$ & $\begin{array}{l}\text { Project: Asset portfolio } \\
\text { decisions of Australian } \\
\text { households }\end{array}$ & $\begin{array}{l}\text { Project: Pathways to state } \\
\text { housing and land tax } \\
\text { reform }\end{array}$ \\
\hline $\begin{array}{l}\text { The benefits of income tax } \\
\text { concessions on housing } \\
\text { investments flow } \\
\text { disproportionately to more } \\
\text { affluent households. } \\
\text { Gradually reducing the } \\
\text { generosity of capital gains tax } \\
\text { and negative gearing } \\
\text { provisions over a decade would } \\
\text { have only a modest impact } \\
\text { on the after-tax return from } \\
\text { housing investments, with the } \\
\text { exact figures depending on } \\
\text { wage income, interest rates } \\
\text { and capital growth. }\end{array}$ & $\begin{array}{l}\text { Age pension eligibility does } \\
\text { not appear to have a } \\
\text { significant impact on housing } \\
\text { decisions. } \\
\text { There is a clear case for } \\
\text { including the value of the } \\
\text { family home in the aged } \\
\text { pension assets test, } \\
\text { although any such reform } \\
\text { should include a } \\
\text { comprehensive deferral } \\
\text { scheme to ensure asset rich, } \\
\text { income poor pensioners are } \\
\text { not disadvantaged. }\end{array}$ & $\begin{array}{l}\text { In the short term, it is } \\
\text { possible to establish a } \\
\text { simpler, fairer revenue } \\
\text { neutral transfer duty } \\
\text { regime in each of the states } \\
\text { under which approximately } \\
60 \text { per cent of property } \\
\text { buyers at the cheaper end of } \\
\text { the market would pay less } \\
\text { transfer duty than under } \\
\text { existing arrangements. } \\
\text { Over the longer term, it is } \\
\text { possible for the states to } \\
\text { transition from this reformed } \\
\text { transfer duty regime to a } \\
\text { broad-based recurrent } \\
\text { property tax. }\end{array}$ \\
\hline
\end{tabular}

Note. For further details, see Chapters 2, 3 and 4 respectively.

Source: Authors 


\section{Policy development options}

The reform program summarised in the below figure rests on the following principles:

- Political and economic imperatives demand a coordinated, long-term approach to housing tax reform informed by shared objectives and a coherent framework for policy change.

- A national reform agenda requires national leadership and, where possible, cooperation from state and local governments.

- A reform strategy should initially focus on setting and agreeing national policy goals and establishing the administrative foundations for reform. It should then move to gradually adjusting policy settings to achieve long-term housing policy goals. 


\section{A coordinated reform pathway}

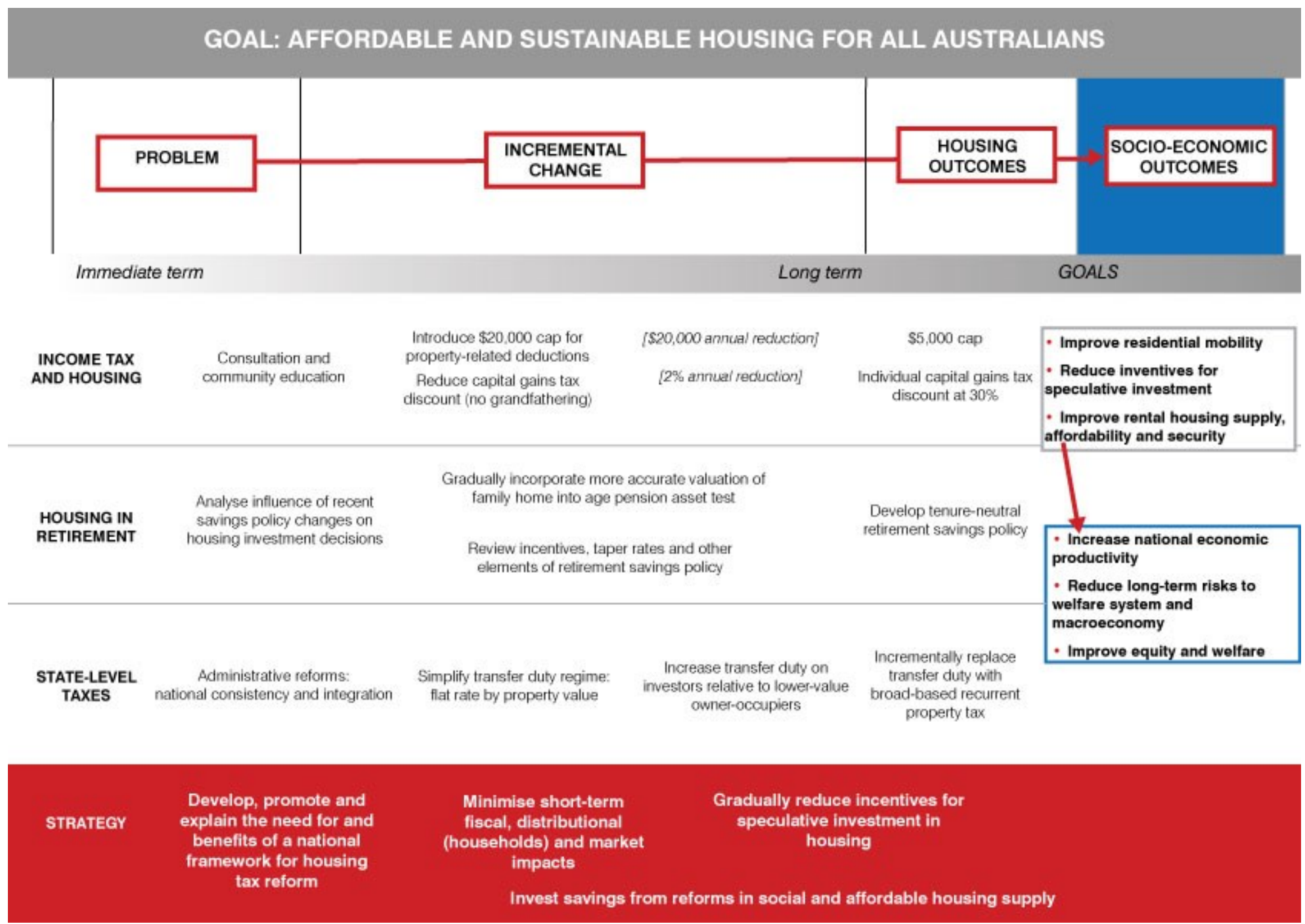

Note: This Figure is further discussed in Section 5.1

Source: Authors. 
The reform pathway described in the figure above is based on detailed analysis of the existing tax policy frameworks at all levels of Australian government combined with a detailed assessment of the prevailing political context and its implications for housing tax reform. This political analysis was then used to inform the design of the empirical research undertaken in each of the supporting projects.

The specific recommendations in each area of housing tax reform are:

\section{Income tax and housing}

1 A cap on housing-related tax deductions should be phased in over a 10-year period, with an initial $\$ 20,000$ cap to be reduced by approximately $\$ 1,500$ per annum (the precise amount would depend on market conditions) until it reached $\$ 5,000$.

2 The CGT discount currently applying to residential property investments should be reduced incrementally over a 10-year period, with the discount rate to be cut by approximately two percentage points per annum (the precise amount would again depend on market conditions) until it reached 30 per cent. Lowering of the CGT discount rate should not be grandfathered to avoid 'lock-in' effects.

3 Revenue raised from reforms to negative gearing and CGT should be invested into the provision of social and affordable housing.

\section{Housing in retirement}

1 The value of the family home should be more accurately reflected in the pension asset test.

2 Taper rates, incentives and other provisions within the retirement income system which benefit households with substantial retirement savings should be reviewed with any savings being used to provide housing support to the growing number of Australians who will retire without housing assets.

3 Changes to the pension asset test should be complemented by a comprehensive deferral scheme to allow 'asset rich, income poor' pensioners to be able to access the aged pension to enable them to age in place.

\section{State property tax reform}

1 State governments, with Commonwealth cooperation, should immediately commence reform of the administrative foundations of the subnational property tax system and should develop:

- a national register of property ownership and use

- a nationally consistent approach to property valuation

- further develop relevant interagency data-sharing

- develop integrated approaches to state and local government property tax collection.

2 In the short term, state governments should simplify their current transfer duty systems by introducing a single flat rate with a tax-free threshold set as a percentage of the median house price. Building on this foundation, states can then, in the medium-term, adjust rates and thresholds as required for different categories of ownership and use.

3 In the longer-term, state governments should implement transitional arrangements to gradually phase in broad-based recurrent property taxes, with the proceeds used to phase out and potentially abolishing transfer duties on residential property. 


\section{The study}

The analysis undertaken for this Inquiry was informed by a political economy approach that sought to reconcile the technical aims of housing policy and tax design with an appreciation of the political barriers to reform. It incorporated input from a range of stakeholders, including members of the Inquiry Panel, concerning both the political context and reform priorities.

Framed on this analysis of the political economy, tax policy reforms were selected, based on an assessment of the existing literature, for their potential to yield insights that could drive significant improvements in housing policy over time. These reforms were then analysed by the Inquiry's three connected research projects, using new and existing datasets and sophisticated modelling techniques.

Specifically, the three supporting projects respectively carried out:

- analysis integrating the Evaluation Model for Incomes and Taxes in Australia (EVITA) and the Australian Housing and Urban Research Institute Housing Market Microsimulation Model (AHURI-3M) to simulate the impacts of negative gearing and capital gains tax reforms respectively (see Chapter 2)

- analysis of the wealth module in the Household, Income and Labour Dynamics in Australia (HILDA) survey to retrospectively model behavioural responses to specific policy changes (see Chapter 3)

- analysis of transfer duty and property tax reform options using CoreLogic's database of all residential property values and transactions in Australia in 2015-16, which is arguably the most comprehensive set of property data currently available (see Chapter 4).

The Inquiry then drew together the findings, within the political economic framework to propose a coordinated, pragmatic and incremental approach to reform. This approach minimises the short-term impact on households, government budgets and housing markets, thereby mitigating political resistance to reform. 


\section{Introduction: housing tax in Australia}

Despite a sustained period of economic growth in Australia, housing affordability and accessibility have declined significantly in recent years. The resulting shortage of affordable housing is having an adverse effect on the housing needs and aspirations of many low and middle-income Australians and, over the longer term, will have a detrimental effect on the economy and society.

Research by academics, government and stakeholder groups suggests that well designed tax reforms can make a significant contribution to improving housing affordability.

However, such reforms face political challenges that present formidable barriers to sustained and genuine policy innovation.

The approach of this inquiry differs from existing literature by adopting a political economy approach which recognises the inseparability of political and economic factors when considering contested policy issues such as housing tax reform. By combining detailed policy analysis with the findings of three connected empirical research projects, the Inquiry establishes a comprehensive long-term reform pathway. Our recommendations meet technical reform objectives, but are also designed to minimise political risks and market disruptions. The overarching goal is to develop a pragmatic, politically viable strategy that contributes to providing affordable and sustainable housing for all Australians.

\subsection{Why this research was conducted}

This is the Final Report of the AHURI Inquiry into 'Pathways to Housing Tax Reform in Australia'. The purpose of the Inquiry was to develop a set of reforms to the taxation of housing and property that will contribute to a fairer and more sustainable housing system. The problems associated with the tax treatment of housing are well understood and reform options are plentiful, yet the political barriers to reform are formidable. As we have noted, this Inquiry adopts a political economy approach, balancing the technical goals of tax reform with an appreciation of the political barriers to policy change, to provide a comprehensive and pragmatic long-term framework for reform.

\subsubsection{The problem: housing}

Australia faces significant housing policy challenges, particularly with respect to affordability. Housing market dynamics are complex so 'affordability' is the sum of a range of factors including the ability to access affordable housing, trade-offs made on quality and location and the range of other costs associated with housing consumption such as taxes and utilities (Rowley and Ong 2012). Current housing need ${ }^{1}$ in Australia is estimated to be 1.3 million households (just under $14 \%$ of all households) and will rise to 1.7 million households by 2025 due to a significant ongoing and future shortage of affordable housing. This will place increasing

\footnotetext{
${ }^{1}$ Need' is defined as households unable to access market-provided housing or requiring assistance in the private rental market to avoid housing stress.
} 
pressure on government housing assistance budgets, especially with regard to the private rental market (Rowley, Leishman et al. 2017). Low-income households and households living in private rental are particularly vulnerable to housing stress ${ }^{2}$ (Yates and Gabriel 2006; Yates, Milligan et al. 2007).

While structural support for owner-occupation (along with owner-investment) continues to be at the core of Australian housing policy (Jacobs 2015), since 2001, house prices have been rising faster than incomes and for first home buyers, the average mortgage has doubled (Rowley and Ong 2012; Lowe 2017). Home ownership rates are in long-term decline for lower income households as well as all age groups under 65 years. As Figure 1 below shows, the trend is particularly marked for the 25-34 and 35-44 age cohorts with implications for intergenerational inequality (Wood, Ong et al. 2014; Daley, Coates and Wiltshire 2017:3).

Figure 1: Home ownership rates by age and income, 1981 and 2016

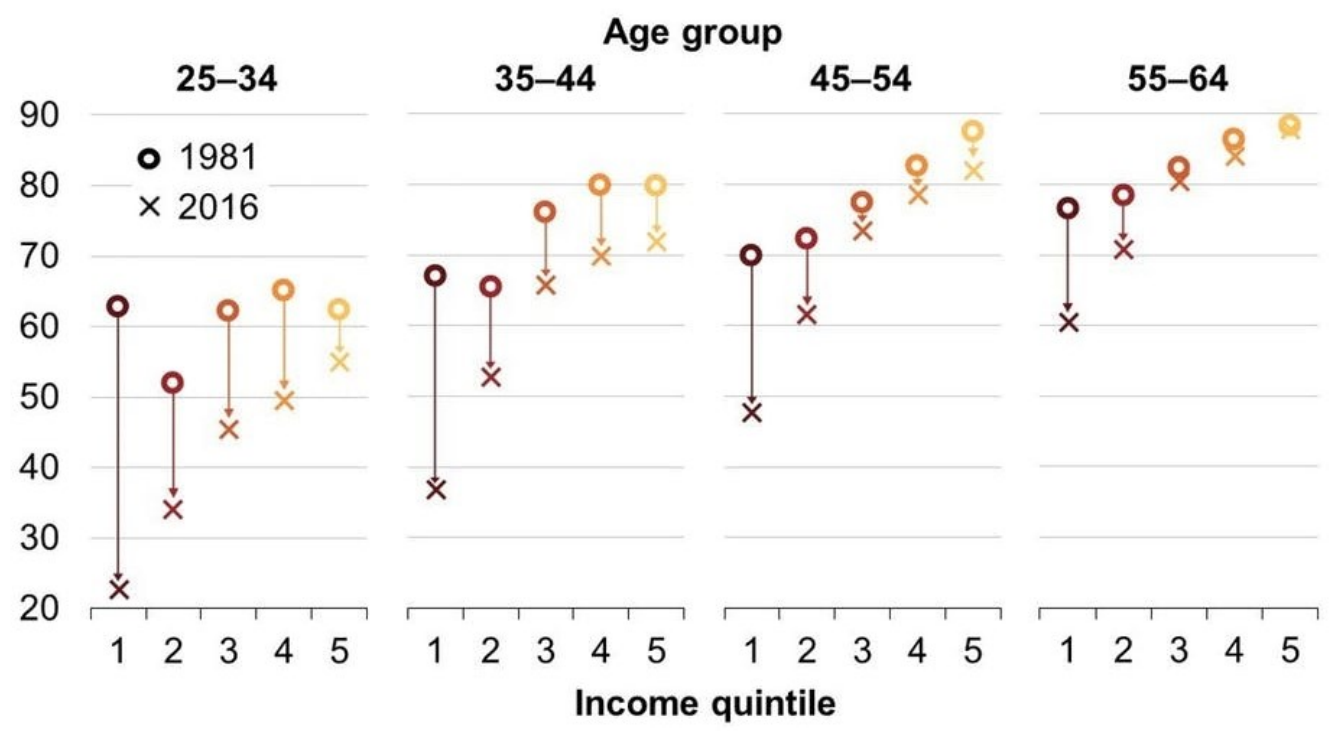

Notes: Updates Burke, T., Stone, W. and Ralston, L (2014) using ABS Census special request data. Household incomes based on Census data are approximate, and so small changes in ownership rates may not be significant. Excludes households with tenancy not stated (for 2016) and incomes not stated. Sources: Grattan analysis of Burke, T., Stone, W. and Ralston, L (2014) Generational change in home purchase opportunity in Australia, 232. Australian Housing and Urban Research Institute; and ABS (2016b)

Source: Reproduced from Daley, Coates et al. (2018).

Compounding this trend is a persistent slowing in wage growth since 2011 (RBA 2017), coupled with the persistent increase in housing values which widens the housing affordability gap between those on lower versus higher incomes. Rising house prices-which are driven in large part by the commodification of established housing and growing demand for housing assets by 'mum and dad' investors-have also pushed household debt to record levels, posing a risk to financial stability and constraining consumption and economic growth (Atalay, Whelan et al. 2017). The 'deposit gap'3 for first home-buyers is now more than double annual household income (Yates 2016). Households unable to buy a dwelling have little option but to rent

\footnotetext{
2 Housing stress is defined in terms of the ' $30 / 40$ rule'. Households are deemed to be in 'housing stress' if they are paying more than 30 per cent of their income on housing costs and are in the bottom 40 per cent of the income distribution (Yates and Gabriel 2006).

3 'Deposit gap' in this case refers to the gap between the cost of a median-priced dwelling and what bank finance would cover for a middle-income household (Yates 2016).
} 
privately. However, the supply of affordable private rental too has steadily declined over the last 25 years and is increasingly concentrated in locations poorly situated in terms of employment options or access to services (Yates 2016). Thus, growing numbers of Australians are living in insecure, unsuitable or poorly-located housing, which is detrimental to community welfare and economic productivity.

The popular and well established strategy of subsidising housing consumption for both owneroccupiers and investors now represents a significant cost to the federal budget. Tax and other expenditure on home owners in 2013 was around $\$ 36$ billion, and this and expenditure on residential property investors accounted for more than 90 per cent of annual government expenditure on private housing market policies. ${ }^{4}$ Those who benefited the least were private renters (Kelly, Hunter et al. 2013). These figures demonstrate that the benefits of housing policy expenditure flow primarily to the better off in the private housing market, not the disadvantaged.

These arrangements are significant social policy concerns because housing is vital for both shelter and non-shelter outcomes. Secure housing is closely connected to employment and educational attainment (Burke, Pinnegar et al. 2007; Dockery, Feeny et al. 2008) and multiple wellbeing outcomes (Smith 2009). Housing affordability also plays an important role in moderating spatial wealth polarisation (e.g. spatial segregation), mobility constraints, and lack of access to labour markets, as well as the increasing disparities between those who can access home ownership and those who can't (Yates, Milligan et al. 2007).

The causes of the housing affordability challenges Australia is confronting are complex and multi-dimensional and include population growth, complex supply and demand issues, infrastructure, planning and investment factors, and government charges and taxes at all three levels of government (National Housing Supply Council 2010; Yates 2008). However, while tax is only one issue among many shaping national housing markets, it is widely agreed that current tax policy settings accentuate intergenerational inequity, inflate housing prices and related distortion of housing property values, reduce mobility, and lower housing affordability, and that reform is needed to address these issues (see Disney 2006; Wood, Ong et al. 2010; Wood and Winter 2012; Wood, Ong et al. 2014; Worthington 2012; Yates 2011, 2012).

Housing tax reform as defined in this Policy Inquiry is an important element of a long-term national housing reform agenda in which policies proposed in this report are supplemented with complementary supply-side and regulatory reforms designed to improve Australian housing outcomes. The contribution of housing tax reforms to a national housing policy agenda are illustrated in Figure 2 below.

\footnotetext{
${ }^{4}$ These policies include land tax exemptions, the pension assets test, the non-taxation of net imputed rents, capital gains tax exemptions and discounts, negative gearing and Commonwealth rent assistance.
} 
Figure 2: Housing tax policy, expenditure and regulation in Australian federation.

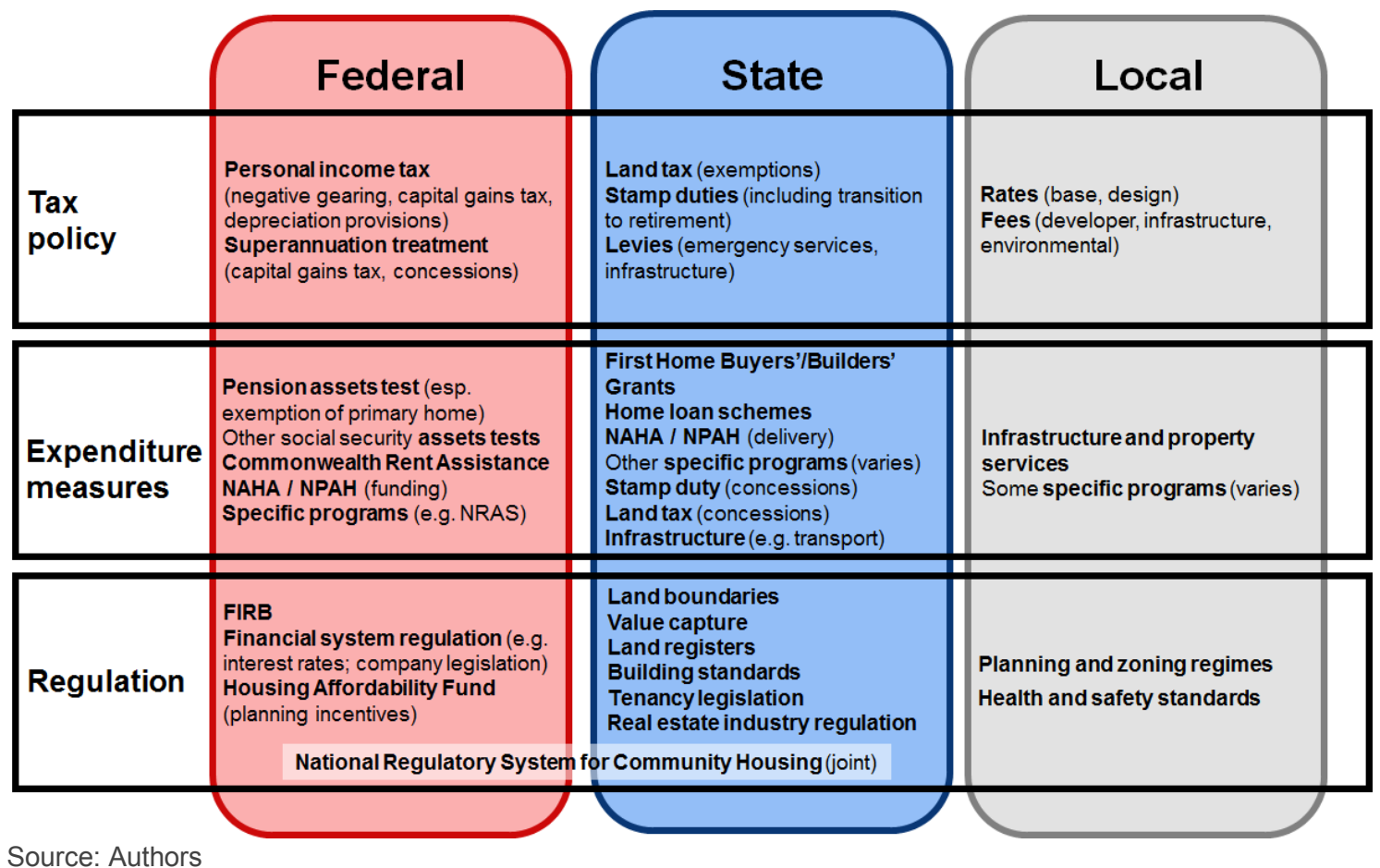

\subsubsection{The problem: tax reform}

As we have noted, there is a growing consensus that Australia's tax system has contributed to poor housing outcomes and economic inefficiency more generally. Government inquiries, think tanks, professional associations and a range of academics have consistently suggested that reforms such as abolishing transfer duty and reforming state land taxes, reducing the CGT discount and limiting negative gearing and changes to the pension assets test would help improve housing affordability (see below).

Despite a strong consensus as to the technical objectives of housing tax reform, formidable barriers persist and to date, housing tax reforms have been piecemeal and ineffective (Eccleston 2013). Housing tax policy in Australia is subject to political barriers and entrenched interests that hinder policy change (Andrews, Sanchez et al. 2011; Evans 2011; Marriott 2010; Minas and Lim 2013), and there is widespread pessimism about the prospects for effective structural reform (Smith 2012; Spies-Butcher and Stebbing 2011).

These barriers include political sensitivities (Evans 2011), the influence of powerful lobby groups in defence of the policy status quo (Gurran and Phibbs 2016), and prevailing cultural norms (Blunden 2016; Khoury 2015; Marriott 2010; Passant 2014; Worthington 2012). Their effect is reinforced by the financial relationship between the Australian Government and the states (Eccleston, Woolley et al. 2013; Eccleston and Smith 2015; Smith 2012; Warren 2010; Wood, Ong et al. 2010), and deeply institutionalised relationships between major political parties and commercial interests which corrode capacity to implement reform proposals (Eccleston and Marsh 2011). These political challenges are compounded by a wider concern that Australia's political leaders are no longer willing or able to promote economic reform in the national interest. In the words of former Treasury Secretary Ken Henry, 'The reform narrative of an earlier period has been buried by the language of fear and anger' (Henry 2017). 
In the broader context of the housing policy aim to improve housing affordability and sustainability for all Australians, and reflecting the prevailing housing tax reform challenge, this Inquiry is guided by the following key research question:

What are the best integrated housing tax reform pathways that are financially sustainable, politically viable, and address tax-related distortions in Australian housing markets?

In the context of this question, we will analyse the objectives of, and barriers to, housing tax reform, asking specifically:

- What are the central goals of the housing tax reform agenda? Can tensions between the objectives of fiscal sustainability, economic efficiency and vertical and horizontal equity be managed?

- What are the major political and institutional barriers to housing tax reform? What policy design features and strategies can be used to mitigate these obstacles to reform?

The first task of this Inquiry was a literature and policy review, the results of which are summarised in the next section.

\subsection{Housing and tax policy reform in Australia}

\subsubsection{The tax treatment of property in Australia}

The taxation of land dates back to ancient times, and until the twentieth century and the rise of income and consumption taxes, taxes and duties on real property were the mainstays of most national tax systems. The nineteenth century American economist, Henry George, perhaps did more than any other to advocate the taxation of land given its potential to generate economic rents (Mangioni 2015).

In the Australian context, federal (introduced in 1910) and state land taxes soon supplemented excise duties as a significant revenue source. The importance of broad-based land taxes may have waned since the 1950s (federal land tax was abolished in 1952), but state land taxes combined with transfer duties on property transactions remain a significant source of state tax revenue while local governments rely heavily on the land tax base. In more recent times (Australian Government 2015; Henry, Harmer et al. 2009), there have been renewed calls to tax land more intensively in order to fund the abolition of inefficient transaction-based duties.

The 2009 Henry Review of the Australian taxation system (Henry, Harmer et al. 2009) gave some consideration to reform of negative gearing, CGT and state tax reform, and produced an associated report on the retirement income system (Henry, Harmer et al. 2009) for joint consideration with the parallel Harmer (2009) review of pensions. Since the Henry review, a number of state and territory governments have undertaken their own reviews of taxation or associated budgetary issues, and these have included consideration of stamp duty and land tax issues (ACT Government 2012; Government of South Australia 2015; Government of Tasmania 2010; IPART 2016; Lambert 2011; Queensland Treasury 2015). There was also some discussion of state taxation in the Australian Government (Brumby, Carter et al. 2012) report on GST distribution, and most recently, the Australian Government's 'Re:think' discussion paper invited and received submissions on a range of taxation questions (Australian Government 2015). The debate concerning the tax treatment of capital gains and negative gearing was also a focal point of the 2016 federal election campaign.

Within the academic literature, concerns tend to centre on the inefficiency and inequity of the current tax system produced by the concessional tax treatment granted to owner-occupiers and 
housing investors and highly inefficient state taxes. It is widely agreed that the outcomes of current tax policies include intergenerational inequity due to the favouring of older and wealthier owner-occupiers and investors, inflated housing prices and the related distortion of housing property values, reduced mobility, and lower housing affordability (see Disney 2006; Wood, Ong et al. 2010; Wood and Winter 2012; Wood, Ong et al. 2014; Worthington 2012; Yates 2011, 2012). There is a consensus in the academic literature on the need to replace transactionbased duties with broad-based recurrent taxes, but there is an active debate as to whether such taxes should be based on the unimproved value of land or the value of property (Ingles 2016, 24). A 'Georgian' tax on land values only captures economic rents and would not act as a disincentive to capital investment on land. On the other hand, a property value tax (which is more common in the UK and US) would act as a partial wealth tax and taxes properties of similar value equally regardless of the value of the land on which they are located. These ongoing debates aside it is clear there would be significant efficiency and housing benefits from moving to a broad-based land or property tax.

\subsubsection{What we already know}

There is a substantial literature detailing how the tax treatment of real property and the income derived from it interacts with other factors to accentuate problematic housing market outcomes. This includes detailed academic analysis (Disney 2006; Wood, Ong et al. 2014; Worthington 2012; Yates 2008; Evans and Krever 2009), significant national inquiries such as the 'Henry' review (Henry, Harmer et al. 2009) and the 'Re:Think' tax discussion paper (Australian Government 2015), the work of independent think tanks such as the Grattan Institute (Daley and Coates 2015; Daley, Coates et al. 2018), and state and territory government reviews of taxation and associated budgetary issues (ACT Government 2012; Government of South Australia 2015; Government of Tasmania 2010; IPART 2016; Lambert 2011; Queensland Treasury 2015). These tell us that tax policy influences the provision of new housing supply and land use, consumer demand for housing, the level of investment in housing relative to other asset classes, methods of financing such investment, labour mobility and the capacity for owner-occupiers to move dwelling in response to changing needs (see Australian Government 2015; Wood, Stewart et al. 2010).

International and comparative research on the relationship between tax policy and housing in other OECD countries highlights how political barriers and entrenched interests hinder policy change (Andrews, Sanchez et al. 2011; Evans 2011; Marriott 2010; Minas and Lim 2013). They also suggest that Australia faces the risk of considerable intergenerational inequity arising from its current tax treatment of investment property ('residential capitalism') and its use of property to build wealth rather than treating housing as a social right (Bourassa and Yin 2008; Mortensen and Seabrooke 2008). More efficient means have been suggested by which Australia could build a sustainable tax base which leads to better housing outcomes (e.g. through consumption taxes, see Bird and Scott Wilkie 2013; or tax on immovable property, see Arnold, Bry et al. 2011; Nooregaard 2013). 


\subsubsection{Policy, practice and debate}

The politically contested nature of housing tax reform is reflected in the contributions that various stakeholders, advocates and commentators have made to the ongoing debate. ${ }^{5}$ Community sector advocates, for example, tend to favour tax reform while the property development sector is generally opposed to change. Economists are generally pro-reform but there are a range of views as to what the priorities for reform should be. Inevitably consultancy firms and other business advocates reflect the interests of their clients and members while think- tanks promote a range of interests depending on the interests of their funders and philosophical and political values they promote.

Overall, most contributors are broadly supportive of reforms such as those considered in this report, or at least, comparatively few are opposed outright. However, the way in which individual contributors define the policy problem which is to be addressed varies widely. Housing advocates tend to highlight declining housing affordability (Australian Council of Social Service et al. 2015; National Shelter 2015; Wood and Winter 2012) and the unfair distribution of the benefits of existing policy settings across tenures or generations (Australian Council of Social Service 2015; Grudnoff 2015b) as the priority for reform. Others, including think tanks and many economists, are concerned with inefficiencies and misdirected incentives in the existing system (Bentley and D'Cruz 2016; Eslake 2015; Grudnoff 2015a; Pape 2016; Quiggin 2015). Recent discussion of 'budget repair' has led some to advocate housing tax changes as a source of additional government revenue (CEDA Balanced Budget Commission 2016; Daley, Wood, et al. 2016; Evans, Minas et al. 2015; Grudnoff 2016).

By contrast, those opposed to reforms either deny problems exist with the status quo (Beckett 2014; Carling 2015; PricewaterhouseCoopers 2016) or argue that existing taxation is already excessive (Property Council of Australia 2015; Real Estate Institute of South Australia and Real Estate Institute of Australia 2015).

The way in which commentators perceive the problem is broadly consistent with their implicit underlying priorities and interests. Those supportive of reform tend to focus on one of three categories: redistributive or equity considerations (Davidson and Evans 2015; Soos 2012), the need for efficient tax system design (Actuaries Institute 2016; DonaldsonWalsh Lawyers 2012; Eslake 2013; KPMG 2015; Productivity Commission 2015), or the need to increase government revenue (Johnston 2016; Stilwell 2004). Among those opposed, the implicit underlying priority is to either reduce the tax 'burden' or to avoid disrupting construction and real estate markets (Oliver 2015; Urban Development Institute of Australia 2015).

Thus, while the question of housing tax reform has become increasingly prominent, rationales, approaches and outcomes remain contested.

\subsubsection{The recent reform agenda}

The recent history of tax reform in Australia begins with the 1975 Asprey review which laid out a broad tax framework, to be implemented over time and established incrementally (Eccleston 2004; Hewson 2014). The Whitlam and Fraser governments did little in response to the review, and it was not until the Hawke government, and the tax packages of 1984-85, that more

\footnotetext{
${ }^{5}$ This discussion is based upon a broad-brush analysis of submissions, research reports, opinion pieces and advocacy documents on negative gearing, capital gains tax, transfer duty, land tax and retirement savings issues, either singly or in combination. These contributions were variously authored by accounting consultancies, business groups, community sector organisations, economists, the housing, property development and real estate industry, political parties, researchers, progressive and libertarian think tanks and commentators on financial policy. It is not a systematic or statistically representative analysis-hence the generalised presentation of the results-but it provides insight into some of the arguments being put to government by stakeholders and lobbyists on these issues.
} 
systematic reform emerged, including new taxes on capital gains and cuts in personal tax rates among others (Phillips 2016).

Further reform packages were developed in following decades under the Keating and then Howard governments, but were thwarted by short-term politics and the political inclination to forgo opportunities for genuine reform given the perceived risks involved. These problems, combined with the political and economic consequences of the financial crisis, also undermined the Henry review (Henry, Harmer et al. 2009) despite its aspiration to address the political barriers to comprehensive tax reform by placing the issue in a broader public policy perspective. Since that review in 2009, some minor recommendations were implemented, although some were quietly repealed by subsequent governments (Hewson 2014).

More recently, housing tax reform became a mainstream political issue during the 2016 federal election campaign, the political legacies of which inform the analysis undertaken in this Inquiry (see the Appendix for summary of major party policy announcements in the lead-up to the 2016 federal election).

In mid-February 2016, the Australian Labor Party (ALP) announced as policy the abolition of negative gearing on most assets (newly constructed properties were an exception) purchased after 1 July 2017 and a halving of the CGT discount to 25 per cent on assets purchased after the same date and held for more than 12 months. ${ }^{6}$ The measures were promoted as making the tax system 'fairer' while contributing an additional $\$ 32.1$ billion to the federal budget over the next decade. The Australian Greens Party released updates to their own negative gearing and CGT policies in June 2016. The Coalition Government, after considering options to cap negative gearing deductions, affirmed its support for the policy status quo, with the Prime Minister stating that the ALP's policies risked disrupting housing markets and would threaten residential construction (Turnbull 2016).

There was some consensus between the ALP, Greens and Coalition in relation to state taxes. Although none of the three parties announced explicit federal policy positions on this issue, all made public statements indicating general support for state tax reform including the replacement of transfer duty with land tax.

These developments are relevant to this Inquiry to the extent that policy issues central to the analysis have become politicised and policy preferences are shaped by technical, distributional and partisan considerations. The analysis presented here is informed by this political context. We propose reforms that balance technical policy objectives with these broader political considerations.

\subsubsection{Reform politics}

The literature on the political barriers to tax reform suggests that even subtle changes such as replacing old and inefficient taxes without increasing the overall tax burden are likely to encounter political resistance. This arises from at least two important characteristics of taxation policy.

1 There is a lack of symmetry in the costs and benefits of tax reform (Sandford 1993: 209). For example, introducing a new tax, or even changing tax rates, has an immediate and tangible impact on a voter's 'hip pocket nerve', while the benefits, such as improving national economic competitiveness or contributing to better housing outcomes, tend to be more diffuse and are realised over the longer term.

\footnotetext{
${ }^{6}$ Assets held by small businesses and superannuation funds would continue to receive a 50 per cent discount under this policy.
} 
2 It is difficult to build political support for reforms that seek to further the national interest over sectional concerns. An efficient taxation system is a 'public good', the benefits of which are dispersed and society-wide. However, researchers who have studied interest group mobilisation argue that 'rational' actors have more incentive to lobby for specific tax settings, resulting in a policy debate dominated by concentrated and politically powerful groups that tend to drown out the disorganised and politically ineffective majority (Olson 1965: 9-16; Peters 1991: 271; Polsky 2000). Evidence relating to interest groups as actors in housing reform is more limited but research suggests the importance of both industry and welfare lobbyists in the policy development process (see Jacobs 2015).

Housing-related tax reform is particularly problematic. Housing is of profound cultural significance, and represents the greatest source of personal wealth for most Australian households. As Eslake (2013) points out, in any given year, the interests of Australia's eight million existing home owners trump the interests of the 100,000 or so first home buyers trying to get a foot on the property ladder.

Thus, there are other barriers to reform specific to the Australian political context:

- The place of the home in Australian society (whether ideological or actual) has led governments to take a conservative approach to reform; the 'Re:Think' tax discussion paper, for example, stopping short of recommending taxing capital gains derived from owner-occupied housing or including the family home in the pension asset means test (Australian Government 2015).

- Given that Australia's housing assets are now valued at over $\$ 7$ trillion, there are wellfounded distributional impact concerns that any significant decline in nominal house prices would affect long-term economic growth (Lowe 2017) and even put Australia's otherwise strong financial system under stress (Shapiro 2017). These broader economic risks both act as a significant barrier to ambitious short-term reforms and add to the case for the incremental strategy advocated in this report.

- Relatedly, there are market impact concerns such as that policy changes will provoke unintended investor market dynamics, whereby implications for property owners will adversely affect lower income consumers such as tenants in the private rental market.

- State governments across Australia rely heavily on revenue raised through propertybased transfer duties and therefore any tax reform pathway must address the significant political challenge of whether it can be implemented without short or long-term detriment to state government budgets.

- There are significant policy differences across major political parties' reform ideas, such as the tax treatment of rental losses and capital gains on residential property investments, or the assessment of housing assets under Australia's retirement savings regime. Thus, individual options have become politicised within Australia's adversarial twoparty system.

- Australia's federal system, especially financial relations between the Commonwealth Government and the states, adds further complexity (Eccleston, Woolley et al. 2013; Eccleston and Smith 2015; Smith 2012; Warren 2010; Wood, Stewart et al. 2010). For example, there is a risk that some states may be penalised for implementing subnational property tax reforms due to the operation of Australia's fiscal equalisation regime. 
Despite these barriers, the outlook for change does appear to be improving. Opinion polls suggest that for the electorate, housing affordability is now the second most important issue (after the health system) requiring Australian Government action (e.g. Australian Housing and Urban Research Institute 2017). The combination of concerns about housing affordability, intergenerational equity and the need for budget repair are such that major political parties are willing to contemplate significant reform, albeit with different underlying objectives. It is the contested nature of these objectives that shape the political economy of tax reform, the implications of which is central to this Inquiry.

In summary, there is broad consensus in the academic and practice literature that housing affordability in Australia has declined significantly in recent years and that tax incentives have contributed to the problem. Systematic housing tax reform can provide partial solutions to the housing affordability challenge. But there are significant political debates regarding the extent to which housing and real property ought to be taxed and the way in which this should be distributed. These challenges are well documented and understood.

This Inquiry has sought to develop, as far as possible within methodological and practical constraints, a reform strategy that is both technically sound and politically feasible to inform and influence the development of tax policy settings into the next decade.

Our ambition is to generate productive debate among stakeholders and policy makers that will contribute to long-run reform. Because of the integrated nature of the Australian housing policy system, discussion should involve all levels of government in the Australian federation and engage industry, academics, welfare groups, and, ultimately, citizens. It is also essential that dialogue extends beyond the consideration of specific reform proposals to include transitional arrangements and compensation options.

It is inevitable that gradually increasing or shifting the tax distribution for millions of Australian property owners will involve political risks and challenges. Ultimately, political leaders will need to articulate how the wider benefits of reform for Australian households, the community and economy outweigh the political costs. 


\subsection{Designing the pathway to reform}

\subsubsection{A strategy for change}

Reflecting the political economy approach underpinning this Inquiry, the analysis is informed by a strategic framework as summarised in Figure 3 below. Our argument is as follows:

1 The significant problems within Australia's housing market are not solely caused by tax policy settings, but many of them are exacerbated by incentives, disincentives and contradictions embedded within the tax system. There are equally significant political and economic challenges involved in reforming the system so that it is more equitable and fair.

2 Therefore, to be successful, any reform agenda must take these challenges into account. They are most effectively managed by ensuring:

- that change is incremental, meaning that movement between old and new policy settings is gradual and open to adjustment should circumstances change

- that reforms do not cause unreasonable disruption to revenue flows or impose significant burdens on lower income or vulnerable households, and

- that changes are politically feasible, which means that reform trajectories minimise shortterm impacts on households, government budgets and wider housing markets.

3 This strategic and pragmatic transition pathway will limit the risk of significant short-term market effects that would undermine the legitimacy of reform, while containing the impact on households least able to cope with the consequences. However, over the long-term, it will support changes within the housing market that ensure Australia is better able to meet the housing needs of all its residents throughout all stages of their lives.

4 Finally, we anticipate that the improved housing outcomes these reforms are designed to achieve will have positive effects in other areas. Housing supports our capacity to engage in education, training and employment, enjoy mental and physical health, and be socially connected to the wider community. Investment in better housing outcomes will, over time, have positive consequences for residential mobility which will benefit both the national economy and the welfare and cohesion of Australian society.

\subsubsection{The what and the how of change}

Within this overarching strategic framework, we have identified certain problems within the housing market to which housing tax reform is a credible, if in some cases only a partial, answer (see Figure 3, column 1). These are:

- a poor match between the characteristics of existing dwellings and the needs of the people who live in them, leading to over-consumption (and, in some groups, under-consumption) of housing, poor urban amenity and locational disadvantage

- declining levels of home ownership among younger, less wealthy cohorts, with significant long-term implications for those households specifically and the welfare system in general due to Australia's reliance on outright home ownership in retirement as the 'fourth pillar' of its retirement income system

- high and rising levels of mortgage-related debt and associated financial stress, the full implications of which are currently suppressed by historically low interest rates but which poses significant risks to household consumption and, in the event of a significant economic shock, a risk to the broader economy, and

- a rental housing market that does not deliver adequate, suitable, affordable and secure housing to a significant proportion of tenants and in which the worst problems are experienced, most acutely by low-income earners and other disadvantaged groups. 
Figure 3: Pathways to housing tax reform: Inquiry conceptual framework

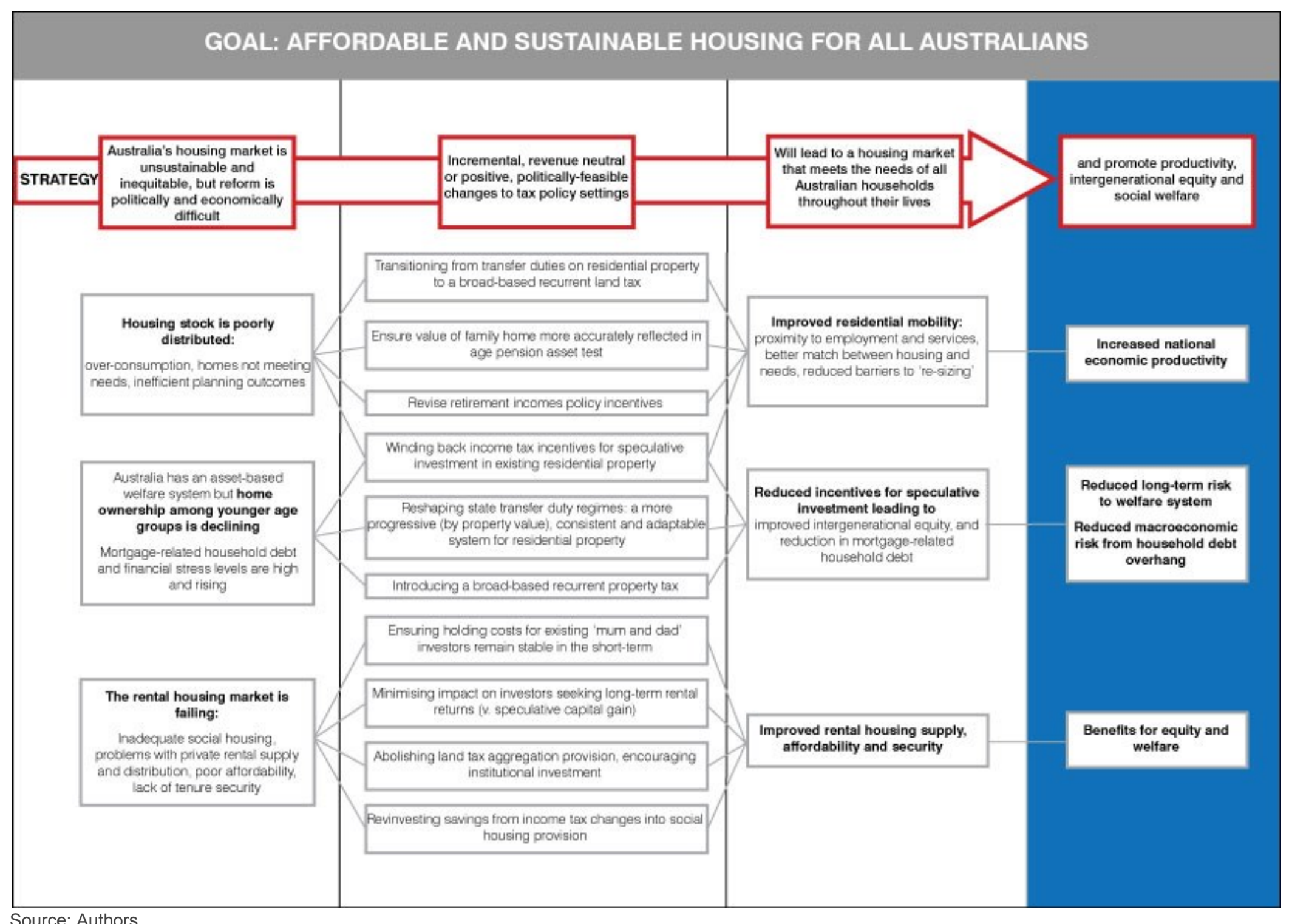

Source: Authors 
The situation is driven, or at least made worse, by the prevailing emphasis on 'investment' in housing to accumulate wealth rather than regard for housing as a social good that should be accessible to the majority of Australians.

As we have noted, these housing challenges are affected by tax settings-transfer duties, for example, can be a financial barrier to moving to more suitable housing, while the combination of income tax concessions available to residential property investors encourages investment for short-term capital gain rather than investing for the long-term.

By identifying tax reform strategies that address these issues in an incremental, pragmatic and achievable way (see Figure 3, column 2), we aim to support more sustainable, equitable and efficient housing market outcomes (column 3). Ultimately, our reform agenda will also generate broader social and economic gains (column 4), including increased productivity and reduced economic risk, and, most importantly, improvements in social welfare and equity.

\section{$1.4 \quad$ Research methods}

This Inquiry is informed by the unifying conceptual framework and objectives described above, while each of the supporting projects within the Inquiry employed methods appropriate to their specific research questions. These are outlined in Table 1 below. The key features of the Inquiry methodology were:

1 Analysis of political and policy context, which involved:

- a literature and policy review of housing affordability issues, historical and current tax reform ideas, and the political challenges associated with tax reform in Australia

- two high-level Panel discussions with national stakeholders from industry and government sectors to assist in consideration of the policy and political issues and agendas influencing the contemporary debate and determine the best pathways to navigate political obstacles to policy change, and

- the development of key internal reports (drawing from the literature review and Panel meetings), in response to which the three supporting projects adopted their specific approaches to analysis.

2 Framing, modelling and empirical analysis, which involved:

- a scenario analysis approach, in which a range of the tax rates and thresholds identified as politically feasible were applied to the proposed bases to highlight the distributional trade-offs associated with different rates and threshold structures (while acknowledging that the issue of tax intensity is inherently political); and

- modelling of transition strategies (in Projects $A$ and $C$ ) to provide governments with the flexibility needed to implement reform across a range of policy environments (see also Table 1 below and Chapters 2-4).

3 Policy recommendations and reform pathways, which involved:

- integration of the findings and analysis from each of the supporting projects

- identification of immediate through to long-term reform measures, their intended and likely housing outcomes, and political strategies to maximise implementation success, including a comprehensive communications strategy, incremental implementation, revenue neutrality and reinvestment in social and affordable housing

- development of the reform pathway outlined in Chapter 5 of this report (see Figure 11). 


\begin{tabular}{|c|c|c|c|c|c|}
\hline Project & Methods & Scope & $\begin{array}{l}\text { Unit of } \\
\text { analysis }\end{array}$ & Data time period & Cohorts \\
\hline $\begin{array}{l}\text { Inquiry: Pathways } \\
\text { to housing tax } \\
\text { reform }\end{array}$ & $\begin{array}{l}\text { Reframing of policy design, including policy review and two national panel } \\
\text { deliberations with range of key policy and industry stakeholders } \\
\text { Three supporting projects modelling impacts across a range of tax } \\
\text { rates/thresholds, including transitional strategies } \\
\text { Synthesis and integration of supporting project findings to develop } \\
\text { principles, design and strategies of tax reform pathway }\end{array}$ & $\begin{array}{l}\text { All } \\
\text { Australian } \\
\text { jurisdictions }\end{array}$ & $\begin{array}{l}\text { Supporting } \\
\text { project } \\
\text { findings }\end{array}$ & - & - \\
\hline $\begin{array}{l}\text { Project A: Income } \\
\text { tax treatment of } \\
\text { housing assets: an } \\
\text { assessment of } \\
\text { proposed reform } \\
\text { arrangements }\end{array}$ & $\begin{array}{l}\text { Policy audit of federal income taxes as they relate to property investment } \\
\text { and ownership } \\
\text { Analysis and validation of the distribution of housing tax expenditures } \\
\text { associated with existing income tax provisions on key housing groups } \\
\text { across multiple datasets } \\
\text { Simulation of alternative negative gearing and capital gains tax reform } \\
\text { scenarios based on different tax bases, rates and thresholds }\end{array}$ & $\begin{array}{l}\text { All } \\
\text { Australian } \\
\text { jurisdictions }\end{array}$ & Household & $\begin{array}{l}2013-14 \text { (ABS } \\
\text { Survey of Income } \\
\text { and Housing) } \\
2001-2013 \\
\text { (HILDA) }\end{array}$ & $\begin{array}{l}\text { Adults (all } \\
\text { ages) } \\
\text { Residential } \\
\text { property } \\
\text { investors }\end{array}$ \\
\hline $\begin{array}{l}\text { Project B: Asset } \\
\text { portfolio decisions } \\
\text { of Australian } \\
\text { households }\end{array}$ & $\begin{array}{l}\text { Desk-based review of age pension means test reforms } \\
\text { Empirical analysis of financial incentives embedded in age pension means } \\
\text { test (descriptive and behavioural) } \\
\text { Empirical analysis of the impact of the removal of the superannuation } \\
\text { surcharge }\end{array}$ & $\begin{array}{l}\text { All } \\
\text { Australian } \\
\text { jurisdictions }\end{array}$ & Household & $\begin{array}{l}2001-2013 \\
\text { (HILDA) } \\
\text { 2002, 2006, } 2010 \\
\text { (HILDA wealth } \\
\text { module) }\end{array}$ & $\begin{array}{l}\text { Pre- } \\
\text { retirement } \\
\text { age }(55- \\
64) \\
\text { Retirement } \\
\text { age }(65- \\
74)\end{array}$ \\
\hline $\begin{array}{l}\text { Project C: } \\
\text { Pathways to state } \\
\text { property tax reform }\end{array}$ & $\begin{array}{l}\text { Policy review of relevant technical and policy literature and associated } \\
\text { political debates. } \\
\text { Empirical modelling using CoreLogic residential property data across a } \\
\text { range of state property tax reform scenarios, including a simpler and fairer } \\
\text { revenue neutral transfer duty regime and the replacement of transfer duties } \\
\text { with a broad-based recurrent property tax }\end{array}$ & $\begin{array}{l}\text { All } \\
\text { Australian } \\
\text { states }\end{array}$ & $\begin{array}{l}\text { Residential } \\
\text { property } \\
\text { (unit, house) }\end{array}$ & $\begin{array}{l}\text { 2015-2016 } \\
\text { (CoreLogic) }\end{array}$ & $\begin{array}{l}\text { Property } \\
\text { owners }\end{array}$ \\
\hline
\end{tabular}

Note. Full methodological details for each supporting project can be found in their respective Final Reports:

Project A: Duncan, A., Hodgson, H., Minas, J., Ong, R. and Seymour, R. (2018) Income tax treatment of housing assets: an assessment of proposed reform arrangements, AHURI Final Report No. 295, AHURI, Melbourne.

Project B: Whelan, S., Atalay, K., Dynan, L. (2018) Asset portfolio retirement decisions: the role of the tax and transfer system, AHURI Final Report No. 298, AHURI Limited, Melbourne.

Project C: Eccleston, R., Warren, N., Verdouw, J. and Flanagan, K. (2017) Pathways to state property tax reform, AHURI Final Report No. 291, AHURI, Melbourne. 


\section{Income tax and housing}

In this chapter, we summarise the findings of supporting project A, 'Income tax treatment of housing assets'. This project focused on negative gearing and capital gains tax. These provisions encourage investment in residential property by both large and small-scale ('mum and dad') landlords, especially debt-financed investment for capital gain.

Detailed and innovative distributional analysis and microsimulation modelling found that most of the benefits of these provisions flow to more affluent households, thereby exacerbating existing income and wealth inequalities.

Some of the distortions could be minimised by targeted, incremental reforms to existing provisions, specifically:

- the introduction of a cap on deductions related to rental losses

- a gradual reduction in the available capital gains tax discount for investment properties.

These changes would limit the incentives for speculative, short-term investment in residential property, restoring some balance to competition between investors and first home buyers.

Phasing in the changes over time would offset perceived political risk and minimise the impact on tenants.

Negative gearing and the capital gains tax (CGT) discount, as they apply to residential property, are two key tax arrangements that have featured prominently in national policy debates. These measures have been shown to exacerbate distortions in property markets and to contribute to poor policy outcomes (Wood, Ong et al. 2010; Kelly, Hunter et al. 2013; Cassells, Duncan et al. 2015; James, Rowley et al. 2015).

The modelling focused on the distributional and revenue consequences of current and future policy settings for individual (not institutional) investors and the transitional arrangements available that might minimise any revenue and distributional pressures arising during implementation of the reforms. It included innovative and sophisticated microsimulation modelling of different reform scenarios and investor types to identify for policy makers the likely 'winners' and 'losers' if policy settings were to be changed (see also Table 1 above and Duncan, Hodgson et al. 2018).

Full details of the methods, analysis and findings of Project $A$ can be found in: 'The income tax treatment of housing assets: an assessment of proposed reform arrangements'. ${ }^{7}$

\footnotetext{
${ }^{7}$ Duncan, A.S., Hodgson, H., Minas, J., Ong-Viforj, R. and Seymour, R. (2018) The income tax treatment of housing assets: an assessment of proposed reform arrangements, AHURI Final Report No. 295, Australian Housing and Urban Research Institute, Melbourne, http://www.ahuri.edu.au/research/final-reports/295, doi: 10.18408/ahuri-8111101
} 


\subsection{The policy challenge}

There are several features of the Australian tax system that affect both the choices people make about housing and the housing market, including:

- negative gearing and capital works write-offs (available to a range of capital investments including housing)

- the main residence CGT exemption (restricted to owner-occupied housing)

- the 50 per cent CGT discount for individuals for assets held for more than 12 months.

Negative gearing allows individual landlords to deduct ongoing expenses related to their investment property from the income (i.e. rent) they receive from that investment. If the expenses exceed the gross rental income, the resulting loss on the rental property can be deducted from other sources of tax-assessable income (Wood, Ong et al. 2011).

Australia has some of the most generous negative gearing provisions within the OECD (Productivity Commission 2004), and the policy has long been perceived as politically 'untouchable' (O'Donnell 2005). When the Australian Government quarantined negative gearing provisions in 1985, this measure was repealed just two years later following a sustained campaign, and as noted by the Senate Economics References Committee (2015, para. 9.65), the effect of negative gearing and its removal remains one of the most contentious areas of tax policy, notwithstanding many calls for reform.

The scale of negative gearing in the Australian residential property market is immense and growing. According to estimates from the Australian Taxation Office (ATO) sample file, 63 per cent of all property investors were negatively geared in 2013-14, compared to just 50 per cent in 1993-94. This translates to a more than doubling in the number of negatively-geared investors, from 500,000 to 1.2 million over the same period (see Figure 4 below). Grudnoff (2015a) estimates that the tax revenue cost related to the negative gearing of investment property in 2014-15 was $\$ 3.7$ billion per year, and that half of this tax break flows to the top 20 per cent of households. 
Figure 4: Percentage and number of property investors who are negatively geared, 199394 to $2013-14$

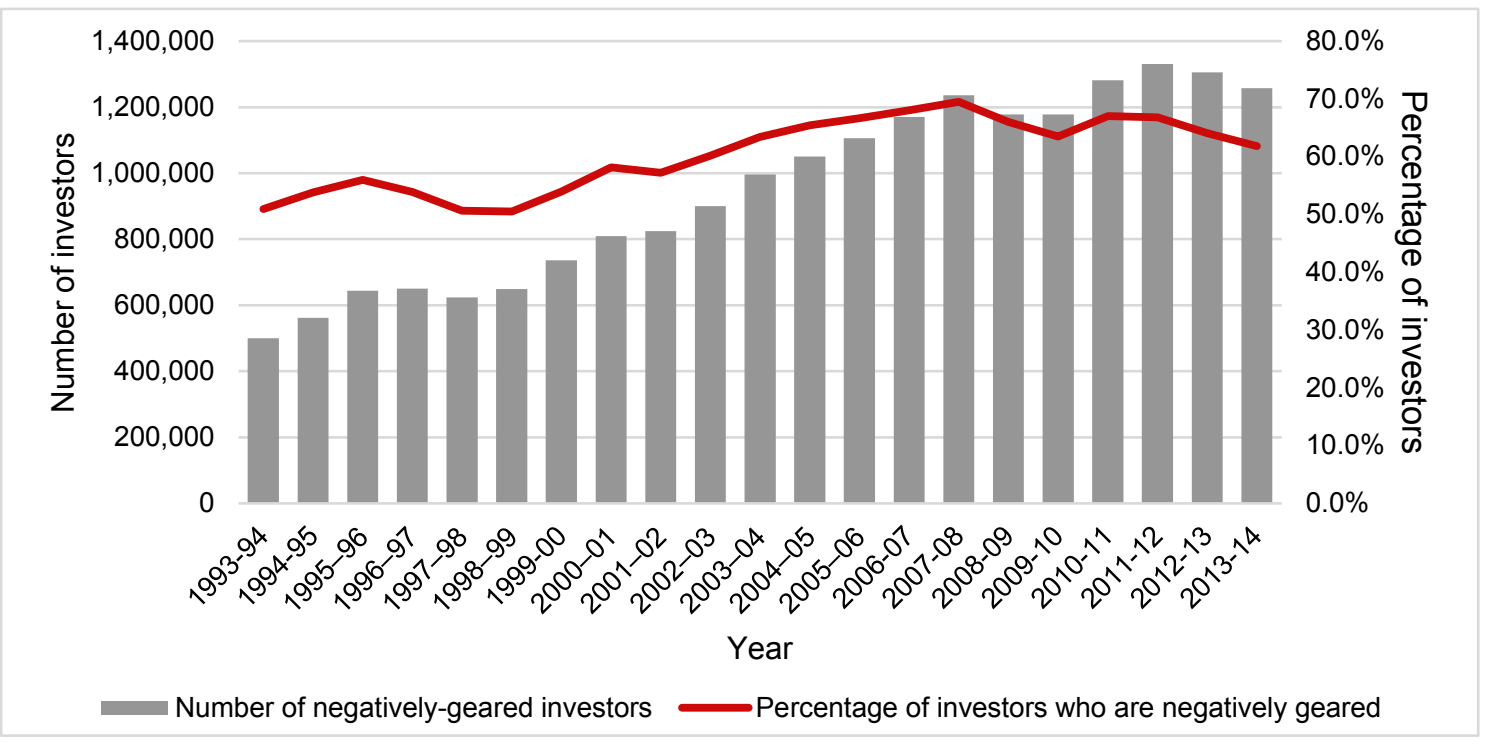

Source: ATO taxation statistics, 1993-94 to 2013-14

Capital gains tax was introduced in Australia in 1985 (Wood, Stewart et al. 2010) as a tax on the capital gains received from the sale of any asset including residential property. Home owners receive a full (100\%) exemption from CGT when they sell their primary residence. A landlord selling an investment property that they have held for more than 12 months is taxed, at their marginal income tax rate, on only $5^{0}$ per cent of their capital gain.

The CGT discount for investor housing for individuals and trusts represented $\$ 6.84$ billion in revenue forgone in 2016-17. Because most capital gains are accrued and realised by taxpayers with high taxable incomes, the benefits of the discount flow disproportionately to these households.

According to the existing literature, in combination these two provisions lead to a distorted and inequitable distribution of housing assets and outcomes in the housing market. In particular:

- the main residence CGT exemption can encourage over-investment in existing housing by established home-owners (Kelly, Hunter et al. 2013)

- negative gearing provisions encourage leveraging (funding an investment through borrowing), but the presence of growing numbers of debt-financed housing investors is a potential source of market instability (Cassells, Duncan et al. 2015)

- the documented problems in the Australian private rental market (Wulff, Reynolds et al. 2011; Hulse, Reynolds et al. 2015; Choice, National Shelter et al. 2017) are aggravated, because

- the CGT discount encourages property investors to maximise speculative capital gain and thus landlords have a disincentive to offer tenants secure, long-term leases,

- property investors are increasingly 'crowding out' first home buyers from the property market (James, Rowley et al. 2015), meaning that to save for a deposit, these 
households are occupying lower-cost rental stock at the expense of more vulnerable and lower income households (Wulff, Reynolds et al. 2011; Hulse, Reynolds et al. 2015),

- rental housing is becoming less affordable in precisely those segments of the market where lower income households typically seek housing (Wood and Tu 2004; Wood, Ong et al. 2010), and

- along with other policy settings, especially company and superannuation tax arrangements, the system discourages institutional investment (e.g. by companies, property funds and financial institutions) in rental housing, even though such investment might help generate supply that offers greater affordability and security to tenants than is currently available (Wood, Ong et al. 2010).

\subsection{Reform alternatives}

Despite the growing consensus that negative gearing and CGT exemption provisions are costly and contribute to poor housing outcomes, meaningful reform continues to be stymied by formidable political obstacles. The most significant of these include:

- the perception that limiting negative gearing is politically damaging given that 1.2 million investors benefit from the current policy

- fear of rapid market adjustments that cause severe disruption and displacement for existing tenants, and

- a political compulsion to protect certain groups within the electorate, such as 'mum and dad' investors, from the consequences of reform.

The first of these obstacles can be partly countered in a point noted by our panel members in reference to the 2016 federal election: that the ALP did not appear to suffer any substantial electoral backlash regarding their policy of restricting negative gearing. The second can be managed by ensuring that reform is implemented incrementally, with any change in settings preceded by a comprehensive campaign to build community awareness of key housing challenges and support for reform. The third obstacle could be addressed by designing measures so that the short-to-medium term effects on 'mum and dad' investors are minimal, even if this means that the reforms themselves fall short of a theoretical ideal.

The full range of proposals modelled in this research and the results of the distributional analysis for each are provided in the project final report (see Duncan, Hodgson et al., 2018). They included providing different rates of negative gearing concession to different categories of investors to cushion the effect on 'mum and dad' investors (by ensuring either low to moderateincome or smaller property portfolio values retain preferential tax treatment), the introduction of a cap on the amount of rental deductions an investor could claim against their income, and a gradual reduction in the CGT discount from its current level of 50 per cent. Each of these options was modelled for a range of different rates and reduction amounts.

In this Inquiry final report, we focus specifically on a deductions cap and a reduction in the CGT discount. These options align with our objectives of promoting residential mobility, reducing incentives for speculative investment and improving access, affordability and security for lower income owner occupiers and tenants in the private rental market. While a system that provides explicit protections to 'mum and dad' investors might be politically advantageous, it is likely to be more administratively complex; the impact on these investors could also be minimised with a rental deductions cap if it were introduced slowly and incrementally. 
Our selected reform options are:

- introduction of a cap on property-related tax deductions, initially set at a generous level (e.g. $\$ 20,000$ p.a.) and then scaled back incrementally over time to a lower level (e.g. $\$ 5000$ p.a.)

- an annual reduction in the CGT discount, from its existing level of 50 per cent to a lower level (e.g. 30 per cent).

Both options are designed to have only a limited immediate effect on existing investors, but both involve establishing a policy framework that can then be modified over time, with the rate of adjustment determined both by market responses and by the inclination of the government of the day. The overall effect is to reduce the incentives embedded in the existing regime to leverage residential property as a speculative investment while ensuring that the transition for households (both investors and tenants) is both smooth and gradual. It also alleviates the need for politically-expedient but administratively complex 'grandfathering provisions' by ensuring that the short-term effect is comparable for both recent and prospective purchasers.

Successful implementation would require any reforms to be supported by a comprehensive community consultation designed to raise awareness of, and educate the wider public around, the need for a reform pathway. This would alleviate the risks of both a partisan politicisation of reform and an irrational, destabilising market reaction.

\subsection{Key findings}

\subsubsection{Existing policies: who benefits?}

We modelled the distributional effects of existing policy to identify and describe 'typical' investor groups benefiting from these arrangements to frame scenarios for the microsimulation modelling. There are clear socio-economic differences between negatively-geared and positively-geared investors and among the four different categories of CGT beneficiaries (i.e. home owners; home owners who also own investment property; rental investors who themselves rent; and renters who own no property). The analysis indicated that:

- Investors who use negative gearing (and therefore who can be described as benefiting from it) are more likely to be male ( $54.2 \%$ compared to $49.1 \%$ of positively-geared investors), employed full-time (68.3\% compared to $40.3 \%)$ and on higher annual incomes ( $\$ 91,105$ before deductions compared to $\$ 78,534) .{ }^{8}$

- Rental investments that begin on a negatively geared basis appear to be terminated earlier than those that start as positively geared.

- The primary beneficiaries of CGT discounts are owner-occupiers who also own at least one rental investment property. These households have an average taxable income of $\$ 81,595$ and a property portfolio worth $\$ 726,438$. Renters, who neither accrue property-related capital gain nor directly benefit from a CGT discount, have an average income of $\$ 30,844$ per year.

\footnotetext{
${ }^{8}$ The average net rental income reported by negatively-geared investors is a loss of $\$ 8,780$, while positivelygeared investors report net rental income of $\$ 15,990$. Negatively-geared investors report sufficient propertyrelated deductions to reduce their taxable income by over $\$ 10,000$ (to $\$ 80,370$ ), while positively-geared investors' income is only marginally reduced once deductions are considered (to $\$ 77,490$ ).
} 
In the case of both negative gearing and discounted CGT, it is higher income earners who benefit the most. Hence, both policies potentially exacerbate economic inequality between high and low-income groups. Negatively-geared investments appear more likely to be for the short-term, suggesting that the availability of negative gearing does not necessarily promote long-term secure rental housing supply.

\subsubsection{Reforming negative gearing: a deduction cap}

In 2013-14, the average actual tax saving because of negative gearing was $\$ 1,615$ per rental investor. The results of the microsimulation modelling of the introduction of a deductions cap for residential property investments are shown in Table 2 below. The modelling demonstrates that compared to the status quo, the effect of a $\$ 40,000$ cap is very slight, reducing the average actual tax savings (that is, increasing the tax paid) by only $\$ 25$ per annum on 2013-14 figures. As the cap is progressively lowered, tax savings are more substantially reduced, but adopting a very gradual approach, such as a $\$ 2,000$ annual reduction in the cap, limits the immediate yearto-year impact of these reductions for individual investors and therefore the associated political risk.

Table 2: Mean tax savings due to rental deduction caps, 2013-14 figures

\begin{tabular}{|c|c|c|c|c|c|c|}
\hline & \multirow{2}{*}{ No cap } & \multicolumn{5}{|c|}{ Rental deduction cap } \\
\hline & & $\$ 40,000$ & $\$ 30,000$ & $\$ 20,000$ & $\$ 10,000$ & $\$ 5,000$ \\
\hline $\begin{array}{l}\text { Mean annual tax savings per } \\
\text { investor }(\$)\end{array}$ & 1,615 & 1,590 & 1,526 & 1,371 & 1,053 & 694 \\
\hline \multirow{2}{*}{$\begin{array}{l}\text { Reduction in annual tax } \\
\text { savings per investor due } \\
\text { to cap }\end{array}$} & - & 25 & 89 & 244 & 562 & 921 \\
\hline & - & 1.5 & 5.5 & 15.1 & 34.8 & 57.0 \\
\hline $\begin{array}{l}\text { Total annual cost of rental } \\
\text { deductions to budget ( } \$ \text { billion) }\end{array}$ & 3.04 & 2.99 & 2.87 & 2.57 & 1.98 & 1.30 \\
\hline $\begin{array}{l}\text { Annual savings to budget due } \\
\text { to cap (\$ billion) }\end{array}$ & - & 0.05 & 0.17 & 0.46 & 1.06 & 1.73 \\
\hline No. of taxpayers affected & - & 18,949 & 61,083 & 113,570 & 272,800 & 515,112 \\
\hline $\begin{array}{l}\text { Proportion of taxpayers } \\
\text { affected }(\%)\end{array}$ & - & $0.2 \%$ & $0.6 \%$ & $1.1 \%$ & $2.6 \%$ & $4.9 \%$ \\
\hline $\begin{array}{l}\text { Proportion of rental investors } \\
\text { affected }(\%)\end{array}$ & - & $1.0 \%$ & $3.4 \%$ & $6.3 \%$ & $15.1 \%$ & $28.5 \%$ \\
\hline
\end{tabular}

Notes: Estimates are population weighted on per capita basis.

Source: Authors' own calculations from the $2013 \mathrm{SIH}$.

Table 2 also shows the estimated cost savings for the federal budget arising from the introduction of a cap. The modelling exercise calculated the total annual cost to the federal budget of rental deductions to be $\$ 3.04$ billion in revenue forgone. The introduction of a $\$ 40,000$ cap would reduce this cost by $\$ 50$ million, and the lowering of a cap would increase these savings further. A $\$ 5,000$ cap would increase the tax paid by individual investors by $\$ 921$ a year and cost the Australian Government $\$ 1.73$ billion less in revenue forgone than under the current system. 
The distributional impact of introducing a rental deductions cap is shown in Figure 5. It confirms that the individual investors-and thus the housing market and the government budget-would experience relatively little immediate change under a $\$ 40,000$ cap, compared to the status quo. As the cap was progressively lowered, the cumulative effect for the market would become more marked but for individual households, the difference arising from each increment would be relatively minor.

Figure 5: Distributional impacts of rental deduction cap reforms, 2013-14 figures

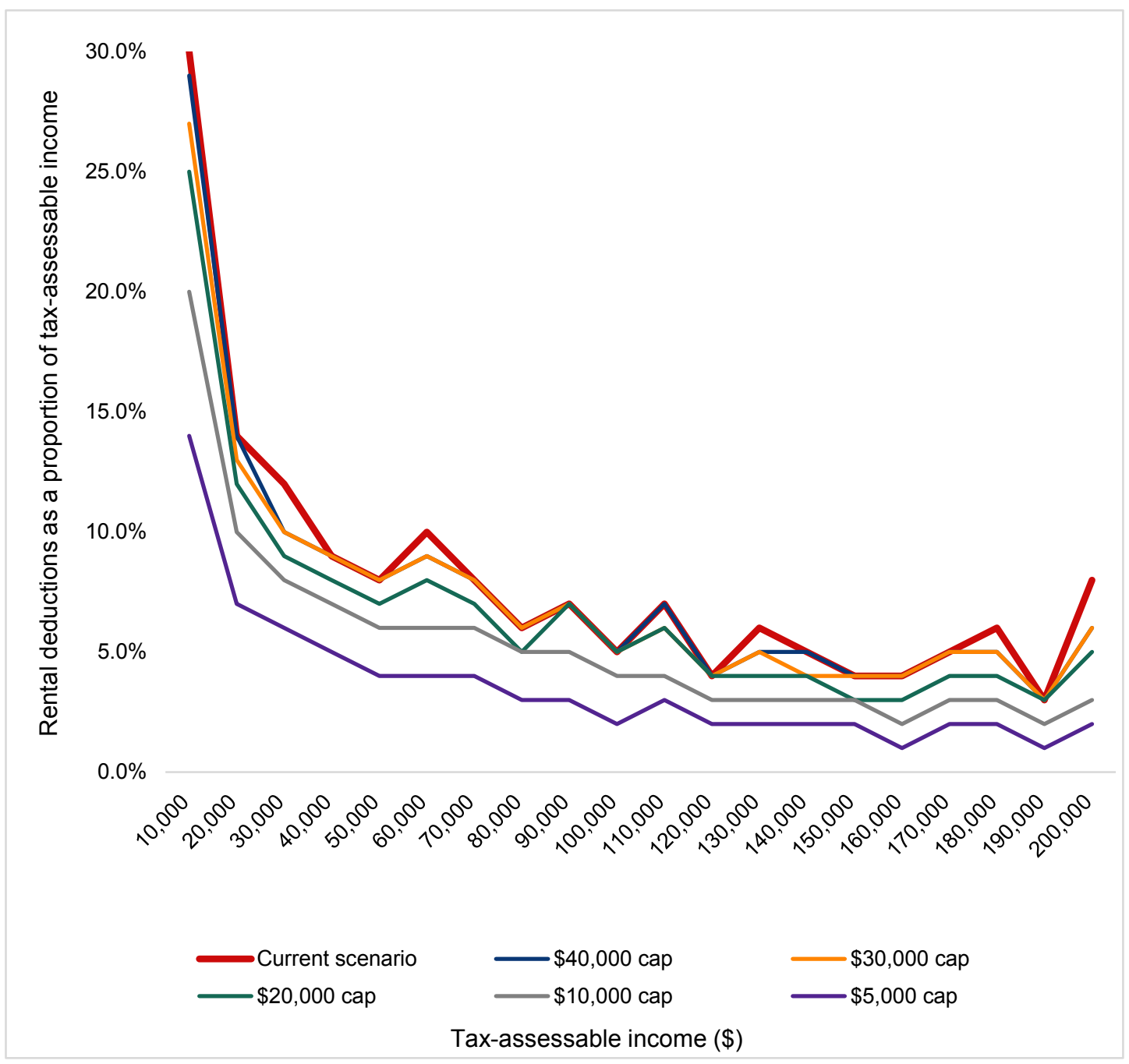

Source: Author's own calculations from the $2013 \mathrm{SIH}$

\subsubsection{Reforming capital gains tax: reducing the discount}

Currently, investment properties (or any assets) held for at least 12 months attract a 50 per cent CGT discount (principal places of residence are entirely exempt). Reducing this discount will diminish the incentive to invest in residential property to secure short-term capital gains. In the interests of administrative simplicity and to avoid 'lock in' effects and short-term market distortions, a gradual reduction in the GCT discount rate should not be grandfathered and should apply to all post-1986 assets. 
Figure 6 below shows the effects of such an incremental reduction for two of the 'typical' investor profiles (identified through the distributional analysis described in Section 2.3.1 above). The scenario shown is for a capital gain of 30 per cent of the property value.

- The 'average income' investor is male, aged 50 and works full-time. His investment property is worth $\$ 350,000$ and his annual income is $\$ 85,000$.

- The 'high income' investor has the same personal characteristics and investment property as the 'average income' investor, but his annual income is $\$ 190,000$.

Figure 6: Impact of reduction in CGT on a $\$ 105,000$ capital gain under different levels of CGT discount: average and high income investors compared

(a) Investor on average income

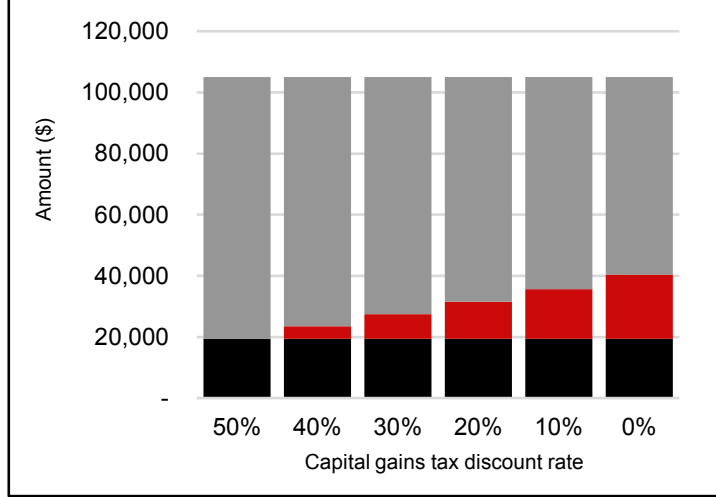

(b) Investor on higher income

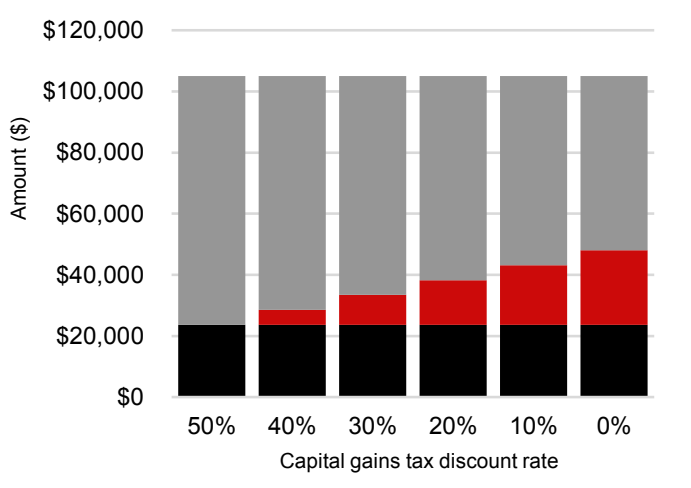

CGT paid under status

quo

(50\% discount)

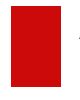

Additional CGT paid under reform scenario
Net capital gain for investor

Note. We assume the typical investor is single with no children. This controls for the impact of a partner's characteristics on after-tax income.

Source: Authors' own calculations from EVITA, $2013 \mathrm{SIH}$.

As Figure 6 demonstrates, reducing the CGT discount rate will also reduce the after-tax or net capital gain for both types of investor, compared to what they would have received under the existing discount of 50 per cent. The effect in absolute terms is most marked for higher income investors (though in percentage terms, the opposite would be the case). However, even in the case of a complete abolition in the CGT discount, both types of investor would in this case still obtain substantial windfall capital gains from the sale of their properties- $\$ 64,562$ for an investor on an average income and $\$ 56,962$ for an investor on a higher income.

One useful measure for understanding the impact of the capital gains tax discount is the aftertax economic cost of holding a rental property. This cost, also referred to as the user cost of capital, is calculated by adding up all costs incurred by an investor, including the cost of paying CGT when the asset is sold, and amortising them over the period for which the asset is held, effectively identifying the annual cost to the investor of owning the property. It is of course a theoretical calculation because CGT is paid as a lump sum, not as a recurrent annual cost, and so isn't treated as an annual cost in practice. 
Based on 2010 figures, our modelling shows that removal of the entire CGT discount (i.e. cutting it from the current 50 per cent down to zero) would increase this 'user cost' figure from 7.4 per cent of the value of the property to 8.0 per cent of property value. If the reduction was introduced in increments (e.g. from $50 \%$ to $40 \%$, to $30 \%$ etc.), then the increase in the after tax economic cost of holding the property is only 0.1 per cent (about $\$ 350$ a year for a $\$ 350,000$ investment) for each 10 percentage point reduction in the CGT discount rate.

These figures underline the value of an incremental reform pathway in containing the year-to-year effects for investors.

\subsection{Implications and recommendations}

The two personal income tax reform options modelled above-the introduction of a deductions cap on residential property and a reduction in the size of the CGT discount-have been identified as making the greatest contribution to our preferred housing policy outcomes of promoting greater residential mobility, reduced speculative investment and improved tenure security in the private rental market. Both reforms will also help to reduce inequity in the current system by narrowing the disparity between higher income earners and lower income earners with respect to the benefits they receive. And by making short-term, capital gain driven investment less attractive, both will dampen enthusiasm for speculation, which currently contributes significantly to Australia's housing affordability problems.

One of the most critical elements in any reform strategy will be clearly outlining and promoting the wider benefits of policy change. Under any reform scenario, investors will derive fewer benefits from the new tax system than they do from the old. Therefore, the case for reform cannot be based on reassurances that nothing will change. Instead, the focus must be the benefits that will flow from change, for the housing market, the community and the broader economy. Support for the reforms could also be strengthened by ensuring that at least some of the budget savings that result is hypothecated to directly addressing housing system shortcomings (e.g. lack of affordable private rental and social housing).

The immediate individual effect of the reforms on investors and their tenants can be managed through an incremental implementation. For example, a more gradual approach will help to avoid the risk of sudden and disruptive market responses that would likely be felt most acutely by lower income landlords and tenants on the margins of the rental market. Importantly, although it will be necessary to ensure there is sufficient policy certainty to guide future investment decisions, the pace of implementation can be slowed or accelerated if required to respond to changes in the market or to wider economic conditions. 


\subsubsection{Recommendations}

- Reforms should be preceded by an appropriate period of community consultation and engagement highlighting the broader benefits of reform.

- A rental deductions cap should be phased in over an extended timeframe. For example, over a 10 -year period an initial $\$ 20,000$ cap could be reduced by approximately $\$ 1,500$ per annum (the precise amount would depend on market conditions) until it reached $\$ 5,000$.

- The CGT discount currently applying to residential property investments should be reduced incrementally over a 10-year period, with the reductions to be approximately two percentage points per annum (the precise amount would again depend on market conditions) until it reached 30 per cent. Lowering of the CGT discount rate should not be grandfathered.

- Revenue raised from reforms to negative gearing and CGT should be hypothecated into the provision of social and affordable housing. 


\section{$3 \quad$ Housing in retirement}

In this chapter, we summarise the findings of supporting project B, 'Asset portfolio decisions of Australian households'. This project examined how tax and transfer policies influence household decisions about housing and wealth in retirement. There is considerable variation in the living standards of retired Australians, some of which is exacerbated by these policy settings and the decisions made in response to them.

To quantify the relationship between retirement savings policy and investment choices in a range of assets including housing, we analysed the effect of two recent changes to retirement incomes policy on household choices, finding that:

- there is little evidence that decisions regarding the family home are influenced by the eligibility requirements of the age pension

- decisions regarding how to structure investment in other forms of assets and savings do seem to be influenced by the financial incentives embedded in retirement savings policy.

Although changes to retirement income rules are politically sensitive, the findings establish that superannuation and age pension policy settings could be better designed to improve housing outcomes.

For example, modifying the age pension asset test to more fully account for the value of the family home would make the test more 'tenure neutral', improving the relative position of pensioners who do not own a home and are exposed to significant financial stress in the private rental market. Any savings arising could be reinvested in providing targeted housing assistance to low-income retirees.

In this chapter, we focus on Australia's retirement savings system. The incentives built into policy settings affect households' wealth management decisions, including how much they invest in assets like their family home and superannuation accounts. Yet the system does not work in the same way for everyone because there is considerable discrepancy in incomes, assets and living standards among older Australians, including with respect to housing.

Using HILDA data, the research team on Supporting Project B conducted a retrospective analysis of how Australians transitioning into retirement respond to incentives in the tax and transfer system (see also Figure 4 above and Atalay, Whelan et al. 2017). Two significant policy changes in 2005 and 2007 (outlined below) were used as an experiment to see if policy change resulted in behavioural change. The results will inform policy makers about how future reforms might play out in practice.

Full details of the methods, analysis and findings of Project B can be found in: 'Asset portfolio retirement decisions: the role of the tax and transfer system. ${ }^{9}$

\footnotetext{
${ }^{9}$ Whelen, S., Atalay, K., Dynan, L. (2018) Asset portfolio retirement decisions: the role of the tax and transfer system, AHURI Final Report No. 298, Australian housing and Urban Research Institute Limited, Melbourne, http://ahuri.edu.au/research/final-reports/298
} 


\subsection{The policy challenge}

Australia's welfare system provides reasonable outcomes for those who retire as outright home owners and who therefore incur minimal housing-related costs in retirement. This form of 'asset-based welfare' has allowed age pension payments to be lower than they would otherwise need to be. Superannuation offers an additional source of income in retirement and there are significant subsidies available to encourage households to invest in superannuation over and above their compulsory contributions.

The publicly-funded component of the retirement savings system, the age pension, is tightly targeted and means-tested (Whiteford 2010). To be eligible, recipients must be aged over $65^{10}$, have been resident in Australia for at least 10 years, and comply with income and asset limits. The amount retirees receive depends on both income (including that of other household members or income from financial assets like superannuation) and asset tests. The asset test involves a taper rate which applies between a lower and an upper threshold. Once the value of a person's assets exceeds the lower threshold, the pension payment they are entitled to declines. Once asset values exceed the upper threshold, pension payments reach zero and the household is no longer eligible for the pension or related benefits such as the pension concession card. Different thresholds apply depending on housing tenure (see Table 3 below). The test applies only to 'assessable' assets, and one of the most significant exemptions from the list of what is assessable is the family home (Henry, Harmer et al. 2009).

Table 3: Age pension asset test thresholds

\begin{tabular}{llllr} 
Household type & \multicolumn{2}{l}{ Single } & \multicolumn{3}{l}{ Couple } \\
Home owner? & \multicolumn{1}{l}{ Yes } & No & \multicolumn{1}{l}{ Yes } & \multicolumn{1}{l}{ No } \\
\hline Lower threshold & $\$ 253,750$ & $\$ 456,750$ & $\$ 380,500$ & $\$ 583,500$ \\
\hline Upper threshold & $\$ 550,000$ & $\$ 753,000$ & $\$ 827,000$ & $\$ 1,030,000$ \\
\hline
\end{tabular}

Note: Figures are correct as at 1 July 2017.

Source: Department of Human Services (2017)

To address fiscal challenges arising from population ageing, policy makers have tried to shape tax and transfer programs in such a way as to influence people's decisions around work and retirement, and particularly, to encourage people to rely on their own savings and investments rather than the age pension. Two policy changes that aimed to encourage such additional savings were implemented in 2005 and 2007 respectively.

- In mid-2005, the superannuation surcharge was abolished. The surcharge was an additional tax applied to superannuation contributions made by high income earners ('high' was defined as an annual income in excess of $\$ 99,710$ in 2004-05). Abolishing it meant that the effective tax rate on superannuation savings was reduced, benefiting workers who were making relatively large contributions to their superannuation accounts.

- In September 2007, changes to the taper rate of the age pension asset test came into effect. Prior to the change, pensions were reduced by $\$ 3$ for every $\$ 1,000$ in assets over

${ }^{10}$ Between 1 July 2017 and 1 July 2023, the age of eligibility is being incrementally increased to 67 . 
the lower threshold. After the change, the reduction was only $\$ 1.50$ for every $\$ 1,000$ in assets. These changes meant that households with larger asset portfolios could have access to some age pension income and to the pension concession card.

Previous research has described the differences in the wealth of households near retirement, including the nature of assets held (Headey, Marks et al. 2005; Finlay 2012). As expected, there are large disparities, although for average households, wealth peaks at or near retirement. Notwithstanding this, for many households, financial security in retirement is becoming increasingly precarious.

Changes in labour market security and a higher rate of relationship breakdown has led to growing numbers of Australians retiring without owning property and without having had sufficient opportunity to accumulate adequate superannuation. Moreover, declining housing affordability and home ownership rates among younger Australians suggest that in coming decades, the number of Australians retiring who either don't own a home or have significant mortgage debt will increase significantly (Eslake 2017). For these households, the age pension is unlikely to offer sufficient income to protect them from financial hardship (Sharam, Ralston et al. 2016). These discrepancies and inequalities make structuring policy incentives in this area a difficult challenge for policy makers.

Earlier research examined how the age pension asset test affected household behaviour and found that the structure of the system may have encouraged households to direct their wealth into their family home to maximise their access to the pension (Atkinson, Creedy et al. 1995). However, other research has found little evidence that households respond to this incentive in practice (Cobb-Clark and Hildebrand 2011). There is very little research available on how people respond to changes in superannuation rules.

\subsection{Reform alternatives}

Apart from the inequity inherent in providing greater benefits to higher income households, the principal housing policy concerns arising in relation to retirement incomes policy are:

- that the age pension asset test encourages older Australian home owners to over-capitalise their family home (i.e. invest in a home to a greater degree than they might otherwise have done) and discourages them from 'resizing' into housing more suited to their needs

- that retirees who do not own their own homes and are therefore living in the private rental market lack enough income to provide them with a reasonable standard of living, particularly if they also have inadequate superannuation.

Currently, due to the different thresholds applied to different tenures, the age pension asset test places a nominal value on home ownership of $\$ 200,000$ (see Table 3). This is not always an appropriate valuation. Many Australians currently eligible for the pension have significant housing assets, with over 20 per cent of recipients holding net wealth of more than $\$ 1$ million (Daley, McGannon et al. 2013).

Establishing a national register of property values and ownership (see Chapter 4) would mean that, over time, the asset test could be modified to reflect all or part of the actual value of owneroccupied housing rather than the current proxy value. This may encourage higher income households to use some of their wealth as a source of income in their retirement, removing their need to draw the age pension.

As well as increasing vertical equity within the system, this could also raise additional revenue for government. Daley, Coates et al. (2018) have calculated that were owner-occupied housing up to the value of $\$ 500,000$ included in the asset test, this would raise an additional $\$ 7$ billion per annum—although any such change would require careful analysis. The savings could be 
hypothecated into housing assistance targeted to retirees who are not home owners, such as age-friendly social and affordable rental housing.

Complicating any reform agenda are the equity and political considerations associated with 'asset-rich, income-poor' pensioners, such as pensioners whose wealth is derived solely from long-term ownership of a family home that has significantly increased in value over time. Many of these pensioners would have difficulties in finding alternative accommodation within the same area but, like most Australians, would prefer to 'age in place'. One option would be to allow them access to the age pension while they remain in the home with government recouping the costs of providing the pension when the home is sold. ${ }^{11}$ For administrative efficiency, this deferral scheme could be integrated with the one proposed in Chapter 4 for recurrent property tax.

With respect to superannuation, reform alternatives are less clear. Research evidence is relatively limited and recent changes have not been in place long enough to confidently identify their effect.

- In the 2016-17 federal budget, the government introduced a superannuation reform package designed to 'improve the sustainability, flexibility and integrity of the superannuation system' (Commonwealth of Australia 2016: 24).

- These changes reduce the degree to which Australia's generous superannuation concessions disproportionately benefit a small group of very high income earners by limiting the amount of superannuation that such households can accumulate (Treasury c. 2016).

- However, as the analysis of earlier superannuation changes (see sec. 3.3.2) suggests, while these reforms may improve equity within the superannuation system itself, they could also result in higher income households diverting their wealth into other taxpreferred assets like housing, to the detriment of good housing outcomes overall.

- In the 2017-18 federal budget, a further superannuation reform was introduced, designed to encourage older people to 'down-size' into smaller properties and potentially free their existing housing for use by younger families.

- The change allows people aged over 65 who are selling their home to divert part of the proceeds into their superannuation accounts.

- Capacity to 'down-size' (or 're-size') can support ageing in place by allowing people to move into more accessible and low-maintenance housing while remaining in the same area in which they were living previously. However, the evidence suggests that downsizing choices are generally not driven by financial considerations (Poterba, Venti et al. 1996; Judd, Liu et al. 2014), and that these changes will primarily benefit high-wealth households.

- Treasury has anticipated the cost of the scheme would be only $\$ 20$ million in 2020-21, which implies the expected uptake will be modest (Daley, Coates et al. 2018: 106).

11 Daley, Coates and Wiltshire (2018) have suggested that a proportion of the property value $(\$ 250,000)$ could be quarantined from the repayment scheme to ensure that pensioners were not at risk of low or negative equity. 


\subsection{Key findings}

\subsubsection{Do households structure their asset portfolios to maximise access to the age pension?}

Using longitudinal HILDA data for 2002-14, we analysed how older Australian households (aged 55 to 74) structure their asset portfolios (i.e. the types and values of assets they own). This analysis showed:

- There are high levels of home ownership among those in the survey sample-over the 12 years, some 80 per cent owned their own home. The family home was a significant asset, representing 35-45 per cent of household net wealth, with the proportional value increasing into retirement.

- Superannuation and other forms of retirement income are also significant, representing 20-30 per cent of net wealth. Retirees also tend to invest in financial assets, mainly equities and stock, but also bank deposits, as a way of providing themselves with an ongoing source of income (this is consistent with the findings of other research, e.g. Cobb-Clark and Hildebrand 2011).

- Older Australians also derive wealth from properties other than their family home. Between 2002 and 2014, 10-15 per cent of the households' net wealth was held in investment properties. The value of these assets declines slightly for households that have transitioned into retirement, suggesting that many people sell their investment properties once they retire.

To understand the effect of the age pension means test on how households structure their asset portfolios, we undertook modelling comparing two groups of households within the HILDA dataset-those in which the reference person was aged between 55 and 64 (the 'pre-retirement cohort') and those in which the reference person was aged between 65 and 74 (the 'postretirement cohort').

This analysis showed:

- Households close to the age pension thresholds are not allocating their wealth into particular types of assets in a way that would maximise their eligibility for and entitlement to the pension.

- Reaching the age of eligibility for the pension does not have much effect on the way households structure their asset portfolios.

The analysis suggests that, in and of itself, the exemption of the family home from the age pension assets test is not a major determinant of decisions when people are planning for retirement.

This finding is counter to current political assumptions. 


\subsubsection{Did the abolition of the superannuation surcharge change households' behaviour?}

The superannuation surcharge was introduced in 1996 and applied to superannuation contributions at a sliding rate up to a maximum of 15 per cent. It effectively increased the tax rate on superannuation contributions for high income earners to up to 30 per cent. Its removal in 2005 therefore provided an effective tax cut on superannuation savings for affected individuals.

The modelling compared two groups of individuals within the HILDA sample, defined by their before-tax income levels. Group 1 contained people who were consistently within the high income category between 2002 and 2005 and who had therefore been fully affected by the reform. Group 2 contained people who had consistently low incomes in the same period, and were therefore not affected at all by the reform. For both groups, we controlled for the effect of age, educational attainment, individual and household income and health status.

Figure 7 below shows the average percentage of before-tax income directed into superannuation by each group both before and after the abolition of the surcharge. Although the percentage is lower for the low-income group than for the high-income group, this difference is not statistically significant. However, the differences in successive years (i.e. the changes over time) were statistically significant.

Figure 7: Mean percentage of before-tax salary contributed to superannuation 20022014: comparison of groups fully affected and unaffected by 2005 abolition of superannuation surcharge

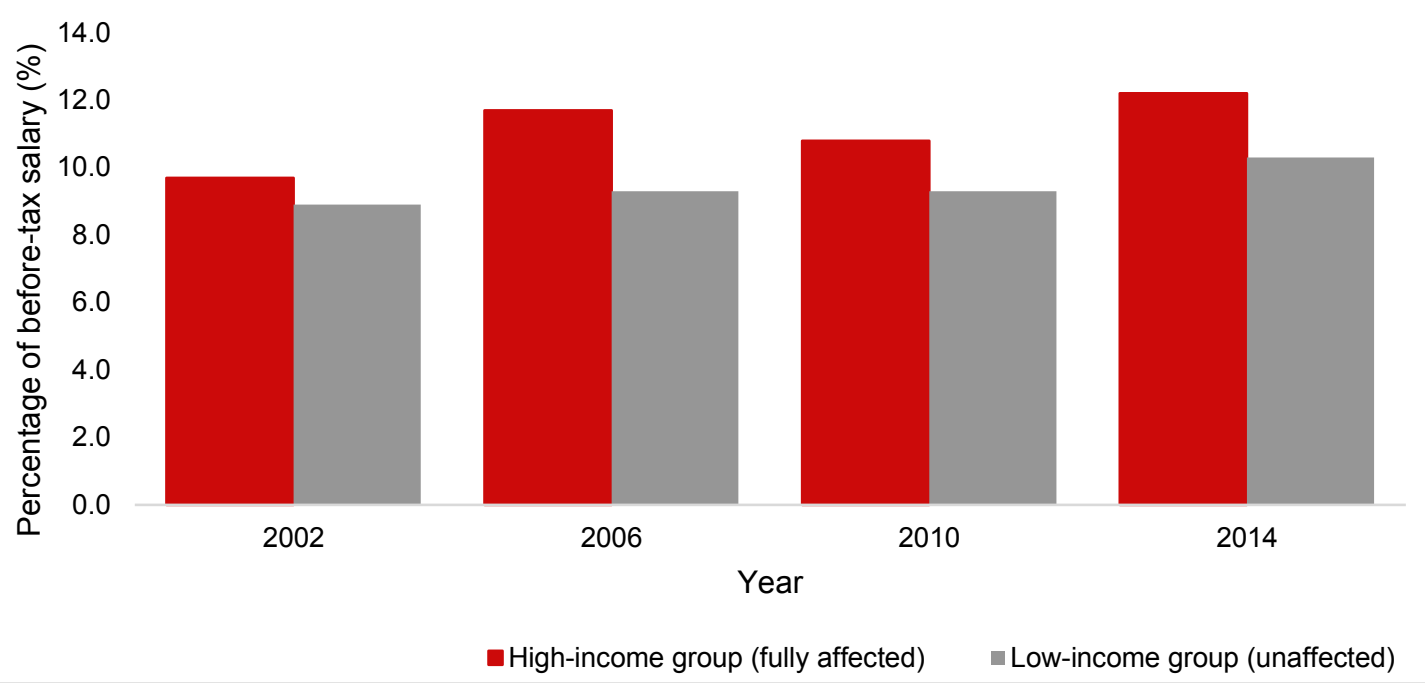

Source: Authors' own calculations using HILDA data.

These results suggest that in the year following the abolition of the surcharge, high income households did increase their superannuation contributions to take advantage of the lower tax rate. This reaction to the policy change seems to have dissipated in later years, although the intervention of the GFC may also have prompted some individuals to move their savings into superannuation. 


\subsubsection{Did changes to the age pension taper rate change households' behaviour?}

The 2007 change to the age pension taper rate had two effects. First, it reduced the de facto wealth tax that the asset test establishes, which meant that affected households could now obtain higher pension entitlements while accumulating greater lifetime wealth. Second, it meant a group of individuals who had previously been ineligible for the pension because they had too many assets were now entitled to receive some pension support.

Again, the modelling compared two groups within the HILDA sample. In both groups, the household head was aged between 50 and 75 and was currently working. Group 1 contained households affected by the change, in that it included households whose pension entitlements changed (i.e. were increased) because of the reforms. Group 2 only contained people who were ineligible for the age pension both before and after the taper rate change and therefore were not affected at all by the reform.

Descriptive analysis indicated that, as would be expected, those in Group 2 were wealthier and healthier and reported higher income levels and rates of home ownership (including of investment property) than were the people in Group 1. Table 4 below shows the change in the way in which members of each group distributed their wealth across different categories of assets-including their own home, other property and superannuation-across three periods of time, 2002-06, 2006-10 and 2010-14.

Table 4: Mean changes in wealth allocations to different categories of assets, 2002-2014: comparison of groups affected and unaffected by 2007 change to age pension taper rate

\begin{tabular}{lrrrrrr} 
& \multicolumn{3}{l}{ Mean changes in investment in selected asset categories (\$) } \\
\cline { 2 - 8 } Asset & $\mathbf{2 0 0 2 - 2 0 0 6}$ & \multicolumn{3}{c}{ 2006-2010 } & 2010-2014 \\
\cline { 2 - 8 } & Group 1 & Group 2 & Group 1 & Group 2 & Group 1 & Group 2 \\
\hline Home equity & 122,400 & 91,500 & 23,500 & 127,700 & $-2,500$ & 20,400 \\
\hline Other property & 5,100 & 133,800 & 16,100 & $-17,500$ & 12,500 & $-85,500$ \\
\hline Superannuation & 1,500 & 96,700 & 22,000 & -600 & 7,500 & 71,700 \\
\hline
\end{tabular}

Source: Authors' own calculations using HILDA data.

Table 4 demonstrates that between 2002 and 2006, the net wealth of both groups in the categories of assets shown grew. In both cases, growth in the value of property, and particularly in the case of Group 1, equity in an owner-occupied home, were significant contributors to this growth. Between 2002 and 2006, households designated in Group 1 increased their equity in their own home by $\$ 122,400$, while Group 2 increased it by $\$ 91,500$.

However, in the subsequent two periods, 2006-10 and 2010-14, Group 2's net wealth declined in several asset categories. In contrast, Group 1 added to their net wealth, but importantly, members of this group appear to have diversified their assets rather than concentrating wealth within the family home. Further statistical analysis of these findings (see Atalay, Whelan et al. 2017) confirmed this interpretation.

The results suggest that, after 2006, households affected by the change in the taper rate invested more in categories of assets that are included in the age pension asset test, such as superannuation and other property, to take advantage of the relaxation in the taper rate. This suggests that the age pension taper rate is a policy lever that can have a large effect on household behaviour. 


\subsection{Implications and recommendations}

The combination of the age pension, compulsory superannuation, voluntary private savings and home ownership have been described as the 'four pillars' of Australia's retirement incomes policy, although the home ownership pillar is 'crumbling' (Yates and Bradbury 2010). The rules and regulations that govern how these elements operate determine household outcomes and are implicated in the governance of ageing in Australia (Power 2017). They are also closely interconnected, meaning that changes to one 'pillar' affect the operation of the other three.

The findings of the analysis in this chapter are nuanced, yet largely consistent with the limited existing research in this area. They suggest that, although Australian households in general do little to deliberately structure their assets to maximise their access to the age pension, higher income earners do actively divert their savings into areas that receive preferential tax treatment or exemptions, such as superannuation or owner-occupied housing, and these households therefore derive the greatest benefit from the retirement incomes system.

Removing the family home exemption from the age pension asset test is therefore unlikely to have a direct effect on housing over-consumption among retirees. This is consistent with other Australian research showing that when older people make choices about housing, lifestyle and health factors are more important than financial considerations (Judd, Liu et al. 2014; Productivity Commission 2015). However, changes to superannuation and age pension policies do affect some aspects of household behaviour, and therefore could be used to drive improvements in housing policy outcomes.

Reform to retirement incomes policy is a politically sensitive area. Altering policy frameworks once people have made significant and long-term financial and personal decisions based on existing settings may be interpreted as unfair. There are a range of vested interests operating in this area and a prevailing sympathy within the Australian community towards age pensioners that can be harnessed to stymy reform. The existing policy framework does contain contradictions, such as the conflict between ensuring that the system encourages rather than discourages individuals to accumulate savings for retirement and measures that ensure that these incentives do not give unnecessary subsidies to households already well provided for.

However, it is also the case that a substantial and growing number of older Australian households are living in financially stressed and insecure circumstances, and that housing, or the lack of it, is one of the main causes of financial hardship (see Sharam, Ralston et al. 2016). Promoting greater tenure neutrality within the retirement incomes system could help protect these households, raising revenue that can be directed into supplying them with more affordable and secure housing options and making a significant, if indirect contribution, to equity, fairness and sustainability within the system. 


\subsubsection{Recommendations}

- The value of the family home should be more accurately reflected in the pension asset test.

- Taper rates, incentives and other provisions within the retirement income system that benefit households with substantial retirement savings should be calibrated to ensure that there is equitable treatment of those who have lacked opportunities to accumulate wealth.

- Reform should be founded on further research, including modelling of the impact across the income spectrum, and carefully designed for incremental implementation.

- Changes to the pension asset test should be complemented by a comprehensive deferral scheme to allow 'asset rich, income poor' pensioners to age 'in place'.

- Any revenue raised from reforms should be diverted into the provision of affordable housing options, particularly age-friendly options, such as social housing and other forms of secure tenure. 


\section{State property tax reform}

In this chapter, we summarise the findings of supporting project $\mathrm{C}$, 'Pathways to state housing and land tax reform'. This project identified a national strategy for the reform of state and local-level property taxes.

In their present form, these taxes are poorly designed and inefficient, impede residential mobility and limit access to appropriate and affordable housing. This project outlines a pathway, staged over the short, medium and longer term, to address these problems.

The approach involves the following steps:

- administrative reforms to ensure coordination and consistency

- creation of a simpler and fairer transfer duty regime

- full or partial replacement of transfer duties with a broad-based recurrent property tax.

These reforms will improve housing outcomes and economic efficiency by enabling greater mobility and will improve access for first home buyers and lower income households by reducing and eventually eliminating transfer duties on lower value properties and supporting greater security for tenants. The pathway is also revenueneutral, so state governments will not experience revenue shortfalls during the implementation period.

In this chapter, we address housing tax policy at the sub-national level, with a focus on transfer duties (also called 'stamp duty') and land taxes. ${ }^{12}$ There is an academic and policy consensus that high dependence on property transfer duties is inefficient and exacerbates the problems in Australia's housing market.

Through comprehensive, detailed modelling using data (extracted and supplied by CoreLogic) relating to all residential property valuations and transactions in Australia in 2015-16, we have developed a nationally coordinated, incremental strategy, including administrative reforms and specific changes to tax policy settings, for the reform of state and local taxation of residential property.

Full details of the methods, analysis and findings of Project $C$ 'Pathways to state property tax reform'. ${ }^{13}$

\footnotetext{
12 To denote specific taxes, we use terms accepted in the international literature including 'recurrent taxes on land' or 'land tax', and 'transfer duties' (rather than the everyday 'stamp duty' or 'conveyancing duty'). In Section 4.3.3 we argue for the implementation of a recurrent property tax on a broad base using capital improved value (CIV) as the valuation method. To distinguish this proposal from the more narrowly-based existing state land tax, we use the term 'property tax' or 'recurrent property tax' to refer to it.

${ }^{13}$ Eccleston, R., Warren, N., Verdouw, J. and Flanagan, K. (2017) Pathways to state property tax reform, AHURI Final Report No. 291, Australian Housing and Urban Research Institute Limited, Melbourne, http://www.ahuri.edu.au/research/final-reports/291
} 


\subsection{The policy challenge}

In Australia, there are currently three forms of subnational tax on land and residential property: transfer duties, state land tax and local government rates (for detail, see Eccleston, Warren et al. 2017). These taxes together raised over $\$ 40$ billion in 2014-15, which was 10.1 per cent of all taxes collected in Australia. They are an important source of revenue for state and local governments, with transfer duty particularly lucrative ( $\$ 18.5$ billion in $2014-15$, or almost half of all property tax).

Despite their revenue significance, however, there is agreement in the literature that state property taxes are poorly designed and require reform. The key points of consensus are that:

- transfer duties on property are inefficient, subject to housing market volatility, and responsible for under-utilisation of housing stock and constrained housing mobility

- introducing a recurrent property tax on a broad base with few exemptions would provide a more stable, efficient source of revenue and bring Australia into line with approaches used in other OECD countries

- local government rates are a stable, reliable and efficient source of revenue, but there are considerable inconsistencies in how they are set, administered and collected.

More specifically, transfer duties impose a large, up-front cost on moving, which means people are discouraged from moving to better suit their health, lifestyle or family size, or to improve their access to work and services. Because transfer duty revenue depends on the volume and value of transactions in the market, it is unpredictable and vulnerable to market disruptions (Henry, Harmer et al. 2009: 253-254; Productivity Commission 2017). Transfer duties also involve a high level of marginal excess burden on the economy, meaning that the impact of raising revenue from these taxes on the consumption of goods and services by households is considerable and detrimental (Australian Government 2015: 24-25).

Shifting to a recurrent property tax would generate a significant efficiency dividend through greater stability in state revenue, improved transparency within the tax system while enhancing residential mobility and housing affordability (Daley and Coates 2015; Henry, Harmer et al. 2009; Mangioni 2016). The benefits of public and infrastructure investments are reflected in land values and so property-based taxation is an efficient means to tax windfall gains (Slack and Bird 2015), allowing the value of public infrastructure investment to be further redistributed through other public investment.

Despite a consensus that reform is desirable, to date the Australian Capital Territory is the only jurisdiction in Australia that has implemented significant changes to property taxes. This is due to a complex political economy, which includes issues such as how to adequately replace transfer duty revenue, how to manage the distributional consequences among households and within the market, and the risks involved in pursuing change in the absence of adequate intergovernmental coordination. 


\subsection{Reform alternatives}

There is a consensus among tax experts as to how property tax systems should be designed which has been reflected in the type of reforms proposed by government inquiries and independent analysts (Henry, Harmer et al. 2009; ACT Government 2012; Bentley and D'Cruz 2016; Daley and Coates 2015; Government of South Australia 2015; Government of Tasmania 2010). These proposals are directed towards enhancing the neutrality and efficiency of the property tax base by replacing transfer duties with broad-based recurrent property or land taxes.

However, as well as technical requirements, any reform pathway needs to take account of the political economy of state tax policy. As with the other reforms outlined in this report (see Chapters 2 and 3), a staged approach with limited initial impact is proposed to offset the political, economic and administrative challenges. The pathway needs to be coordinated across states and levels of government, but allow for local flexibility on rates, thresholds and reform trajectories. It should also be structured to ensure it delivers better housing outcomes for the Australian community.

Our analysis demonstrates that a 'layered' transfer duty regime that is based on a simpler, more equitable foundation can then be adapted to meet specific needs of individual states. For example, the progressivity of the system could be increased by 'layering' an additional surcharge onto investors buying established properties or purchasers of higher-value homes while reducing the tax rates paid by first-home buyers or purchasers of lower-cost properties. Such adaptations of the basic model should help address the long-term decline in home ownership among younger and lower income groups.

In the longer term, a broad-based property tax will help to improve residential mobility with significant dividends for the national economy and community wellbeing. It will also contribute to housing accessibility and affordability:

- Future property tax liabilities will over time be capitalised into, and therefore put downward pressure on, house prices. For example, empirical analysis of the impact of the ACT reforms on house prices in Canberra confirmed that the prospect of increasing land taxes curbed property price growth and potentially saved average purchasers $\$ 1,000$ to $\$ 2,000$ in annual mortgage repayments (Murray 2016).

- The shift from transaction-based property taxes to recurrent property taxes will tend to shift the distribution of property taxes from younger home buyers in urban areas (who are likely to make more purchases over their lifetimes) to older and established home owners. This shift in distribution should, over time, help improve home ownership rates and address intergenerational inequality.

A feature of existing state land tax schemes in many jurisdictions is the use of aggregation, under which owners with multiple properties pay their land tax based on the aggregate value of their holdings, not on the value of each property. This means that institutional investors pay a higher average land tax rate on their property portfolio than a small-scale or 'mum and dad' investor, which deters large-scale rental housing investment. The abolition of aggregation removes the disincentive and would assist in improving the supply of affordable, secure rental housing, particularly for lower income earners. 


\subsection{Key findings}

This section outlines a reform pathway for state and local property taxes. The pathway is designed for sequential implementation across the immediate, short, medium and long-term. These components are summarised in Figure 8 and outlined in Sections 4.3.1-4.3.3 below.

Figure 8: A pathway to state property tax reform

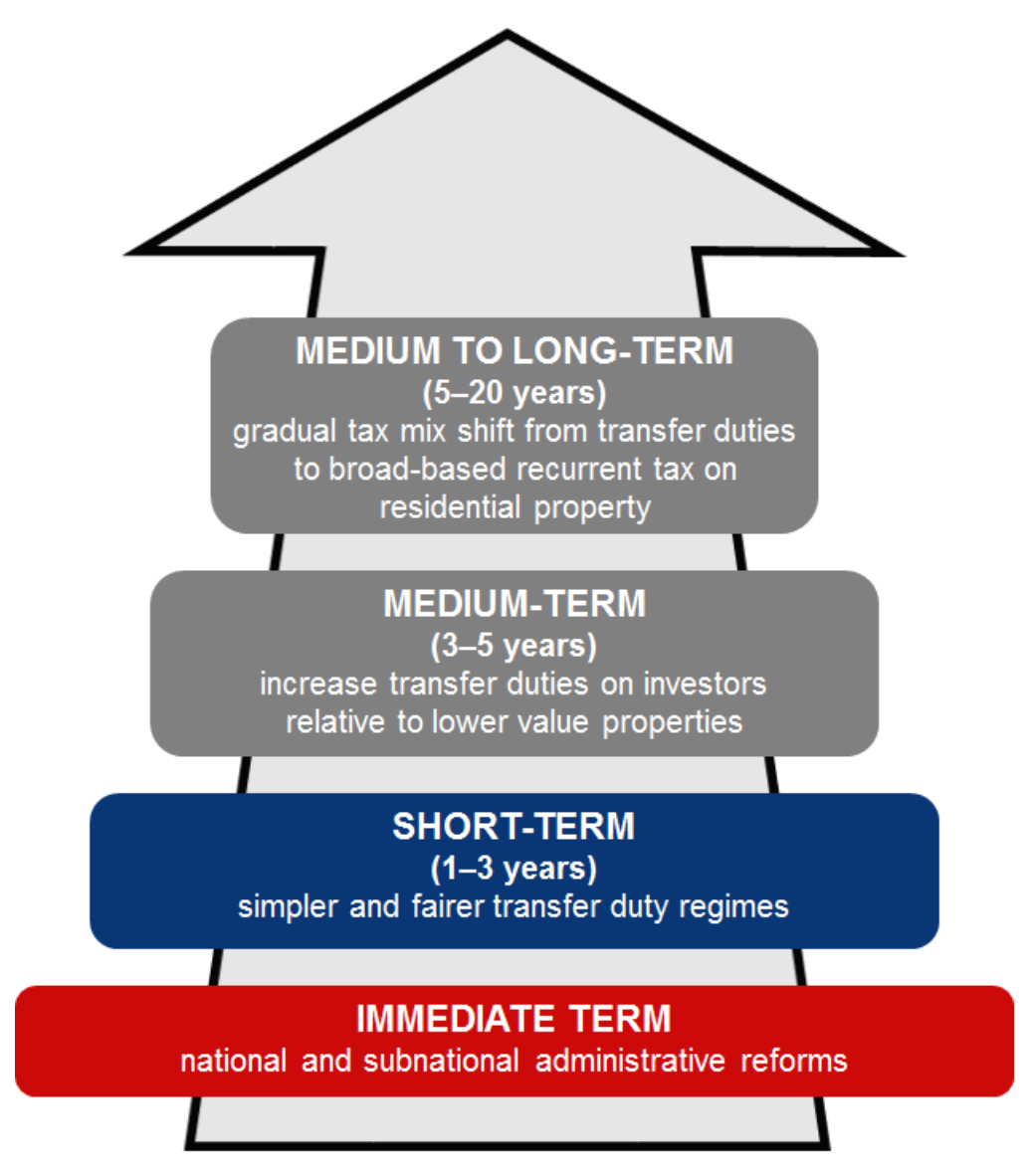

PROPERTY TAX REFORM

Source: Authors.

\subsubsection{The foundations of reform: property tax administration}

Australia is unusual in that local and state governments share access to the property tax base, but do not share administration or valuation functions or coordinate tax rates and structures, resulting in considerable variation across local and state boundaries (Mangioni 2016: 34). This administrative inconsistency is compounded by a lack of data on the identity of owner-occupiers and investors and the use they make of their properties. Currently, each state and territory has its own land registry, but all face challenges with data quality and compliance. 
Improving the administrative foundations of property tax systems will provide a sound basis for reform. These reforms will require:

1 A national register of beneficial owners of residential property, including foreign purchasers

This would enable governments to assess the distribution of property ownership and wealth in Australia and provide an efficient platform on which to implement a layered property tax regime that has the potential to impose differential taxation based on ownership and use. A national register would also enhance compliance in relation to a range of other state and federal taxes. Notable international exemplars of the use of national registries are Denmark and New Zealand.

2 A national approach to property valuation

The significant differences in rate bases and valuation methods in use across Australia affects the capacity and efficiency of local tax-raising efforts (Australian Government 2015: 149). A standardised valuation regime based on capital improved value (CIV) with the broad proviso that the property is being used for its 'highest and best use' (HBU) (see Mangioni and Warren 2014) offers the best approximation of market value. This, rather than imputed rent, is a more intuitive option for owners. As is increasingly the case in other countries, a national valuation regime should make extensive use of well-established automated valuation systems such as that applied when creating the CoreLogic dataset of residential valuations used in this study.

3 Intergovernmental cooperation and data-sharing

Systematic, nationally-coordinated sharing of data on the ownership and use of residential property would assist in reducing compliance and administration costs and improve transparency and system integrity. Specific initiatives would include making ATO and immigration data available to state revenue authorities to help clarify matters of use and ownership.

4 Integration of state and local government property tax administration

This would include the integration of existing tax collection systems (including joint billing of rates and recurrent property taxes) and the use of common valuation methods (see Mangioni 2015: 346). Such integration would reduce administrative and compliance costs and do so without the need to develop an additional administrative system.

\subsubsection{Simplifying transfer duty design}

Transfer duties are a significant source of revenue for all Australian states and territories. However, the design of this tax, in relation to both its base and schedules, has become increasingly complex and contrary to best practice.

The model recommended here is the creation of a single rate of duty with a relatively large taxfree threshold, set as a percentage of the median house price in each state. The threshold ensures that lower value properties are subject to lower average rates of duty. This model would deliver fairer housing outcomes in the short term while providing a foundation for the medium term transition from transfer duty to recurrent property tax. 
The modelling was premised on the following principles:

- it applies only to residential property

- the new regime raises the same amount of revenue as existing transfer duties in each state $^{14}$

- the three scenario rates broadly replicate the average rates in existing regimes, although a higher rate will result in a larger threshold and a more progressive structure

- we assume there is no behavioural response. ${ }^{15}$

The distributional impacts of the proposed model are shown in Figure 9 below. The proposed schedule (especially with a flat rate of $7 \%$ ) is progressive by property value, meaning that purchasers of high value properties will pay marginally more transfer duty than they do now. However, most purchasers would pay less than they do under the current system.

Figure 9: Thresholds and 'break even' points (percentage of purchasers paying less and maximum property value below which purchasers would pay less) under the new regime

Legend

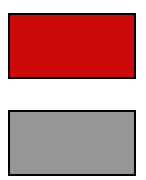

Threshold (\$)

(properties below this value pay $0 \%$ transfer duty)

Break-even point (\$)

(properties below this value pay less than now)

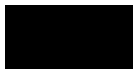

Median property price (\$)

(statewide, houses and units)

$\square \quad$ Purchasers paying less than now (\%)

\section{(b) $6 \%$ transfer duty rate}

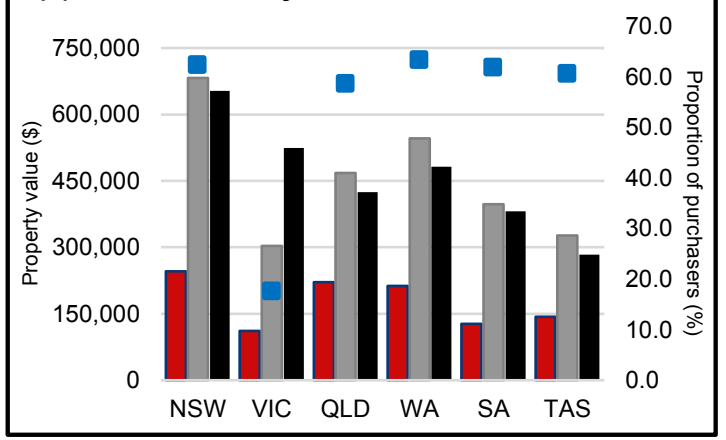

(a) $5 \%$ transfer duty rate

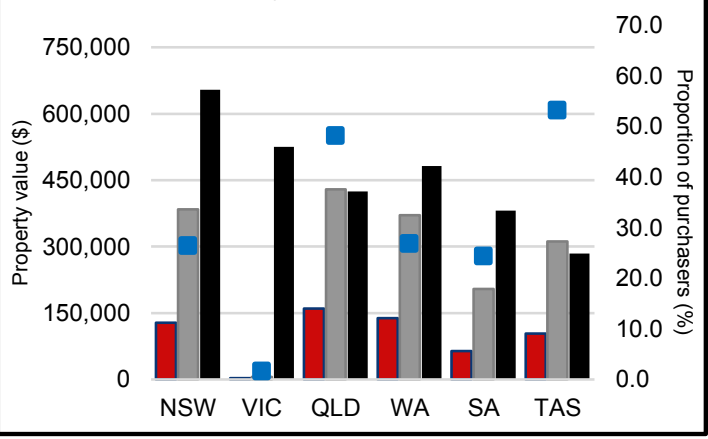

(c) $7 \%$ transfer duty rate

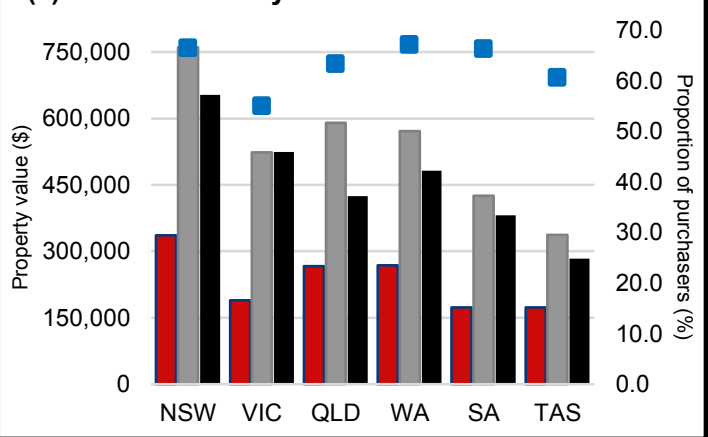

Note: Figures are approximate with an error rate of 1-2 per cent owing to the use of grouped data. The Victorian case is complex due to the interaction of concessions on the principal place of residence. Most home buyers willpay less than currently, but a subset of buyers purchasing properties valued between $\$ 304,500$ and $\$ 550,000$ would be paying more than currently. The model would have to be adapted for the Victorian case.

Source: Authors' own calculations using CoreLogic data.

\footnotetext{
${ }^{14}$ Modelling excludes the ACT and the Northern Territory because the former is already on the path towards phasing out transfer duties while the subnational property tax regime in the latter differs significantly from that found in the states due to the absence of a territory-level land tax.

${ }^{15}$ By assuming no behavioural response, we are clarifying the question of whether change is feasible prior to considering behavioural responses (which might not emerge for some time). Once the case is made for reform, it will be possible to undertake further work to establish likely behavioural responses and their potential influence.
} 
Taking New South Wales as an example, under a 6 per cent flat rate, properties valued below $\$ 245,529$ incur an effective transfer duty rate of zero, but 62.3 per cent of all purchasers and purchasers of all properties valued up to $\$ 682,500$ still pay less than they do under the current system. For each rate, the modelling ensures that state governments will obtain the same amount of revenue under the new model as they currently receive under the existing system. The precise thresholds for specific transfer duty rates in each state are presented in table 5.

Table 5: Thresholds (\$ value and percentage of median house price) required to achieve revenue neutrality at different rates of transfer duty

\begin{tabular}{lrrrrrrrr} 
& \multicolumn{2}{c}{$\begin{array}{c}\text { Median } \\
\text { house }\end{array}$ State } & \multicolumn{2}{c}{ Rate: 5\% } & \multicolumn{2}{c}{ Rate: 6\% } & \multicolumn{2}{c}{ Rate: 7\% } \\
& price $\mathbf{( \$ )}$ & \multicolumn{1}{c}{ Threshold } & \multicolumn{2}{c}{ Threshold } & \multicolumn{2}{c}{ Threshold } \\
\hline NSW & 653,697 & 128,451 & 19.7 & 245,529 & 37.6 & 335,804 & 51.4 \\
\hline VIC & 635,872 & 3,412 & 0.7 & 110,905 & 21.1 & 189,332 & 36.1 \\
\hline QLD & 424,966 & 160,000 & 37.7 & 220,983 & 52.0 & 267,006 & 62.8 \\
\hline WA & 481,605 & 138,221 & 28.7 & 213,351 & 44.3 & 268,736 & 55.8 \\
\hline SA & 381,059 & 63,827 & 16.8 & 127,274 & 33.4 & 173,839 & 45.6 \\
\hline TAS & 283,886 & 103,618 & 36.5 & 143,078 & 50.4 & 173,738 & 61.2 \\
\hline
\end{tabular}

Source: Authors' own calculations based on CoreLogic data.

The model shown in Figure 9 can function as a base upon which governments can adopt different rates and thresholds based on variations in ownership and use. For example, the cost of proportionally reducing transfer duty for lower value owner-occupied housing can be offset by proportionally increasing costs on investment properties. This strategy, which is effectively a surcharge on investors relative to owner-occupiers, has two implications. First, the incidence of higher transfer duty charges will fall on higher value investment properties. Second, there is scope to vary the amount of revenue raised (and the magnitude of the difference in treatment of investors and owner-occupiers) by varying the size of the surcharge. In other words, the reform is scalable. Governments can retain the duty-free threshold for all properties but charge different duty rates according to how a property is used.

\section{Options for 'layering':}

The baseline option of a 6 per cent flat rate (see Figure 9) could be adjusted so that the same amount of revenue was raised, but the rate for investors was one percentage point higher than the rate for owner-occupiers. In New South Wales, this would mean that both investors and owner-occupiers would receive a duty-free threshold of $\$ 245,529$, but on the value in excess of this amount, owner-occupiers would pay a transfer duty rate of 5.88 per cent while investors would pay 6.88 per cent. For a median value property $(\$ 653,697)$, our modelling indicates that with these different rates, investors would pay $\$ 3,588$ more than under the baseline reform, and owner-occupiers would pay $\$ 490$ less.

Other variations include surcharges on particular categories of purchaser, such as non-resident foreign buyers or buyers of especially high-value or 'premium' properties, or alternatively, additional concessions (beyond the standard threshold) to others, such as first home buyers. Many of these measures exist in the existing 
system, but have been applied in an ad-hoc and opportunistic way. The simplified transfer duty regime outlined here acts as a framework within which they can be applied systematically and transparently.

As noted in the the full report on Pathways to state property tax reform (AHURI Report, No. 291: 66-67), this differential tax treatment of properties depending on their use would require carefully designed integrity measures to ensure purchasers didn't game the system. 


\subsubsection{Changing the mix: transfer duty and recurrent property tax}

According to policy stakeholders, one of the greatest barriers in transitioning from transfer duty to a recurrent property tax is the process by which this transition is accomplished, rather than the second order issues of a recurrent property tax being more 'visible' to taxpayers, or that asset rich but cash poor home owners would struggle to pay. Following assessment of a range of different models, we identified a 'phase out, phase up' model as the most appropriate, as it is revenue-neutral and avoids the lock-in effects of 'grandfathering' elements of the current regime. This is the strategy adopted in the ACT.

We argue that the new recurrent property tax should be imposed on the broadest base possible and use a CIV plus HBU valuation method (Daley and Coates 2015; Kelly, Hunter et al. 2013; IPART 2016; Mangioni and Warren 2014). The model is designed to be layered onto the existing land tax regime and assumes that the baseline reform to transfer duty (see Section 4.3.2 above; modelling is based on the $6 \%$ flat rate option) has been implemented and that administrative integration with local government rates collection is established.

The modelling results in Table 5 below show the required rate of property tax to reduce the transfer duty rate from 6 per cent to 3 per cent while raising the same amount of revenue. That is, in New South Wales, revenue neutrality could be maintained with a transfer duty rate of 3 per cent and a recurrent property tax rate of 0.1586 per cent on the value above the tax-free threshold. Under this system, a purchaser of a median-priced house would pay $\$ 12,231$ in transfer duty and incur an ongoing property tax liability of $\$ 647$ per annum.

Table 6: Required rate of recurrent property tax (paid on value above threshold) to reduce transfer duty rate from $6 \%$ to $3 \%$ and indicative annual payments for both, all states

\begin{tabular}{lrrrrr} 
State & $\begin{array}{l}\text { Median } \\
\text { property } \\
\text { price (\$) }\end{array}$ & $\begin{array}{l}\text { Threshold } \\
(\mathbf{6 \%} \text { rate) }\end{array}$ & $\begin{array}{l}\text { Required } \\
\text { property } \\
\text { tax rate (\%) }\end{array}$ & $\begin{array}{l}\text { Transfer duty paid } \\
\text { (median-priced } \\
\text { house, 3\% rate) (\$) }\end{array}$ & $\begin{array}{l}\text { Annual recurrent } \\
\text { property tax paid } \\
\text { (median-priced } \\
\text { house) (\$) }\end{array}$ \\
\hline NSW & 653,697 & 245,529 & 0.1586 & 12,231 & 647 \\
\hline VIC & 524,872 & 110,905 & 0.1531 & 12,416 & 634 \\
\hline QLD & 424,966 & 220,983 & 0.1914 & 6,119 & 390 \\
\hline WA & 481,605 & 213,351 & 0.1238 & 8,058 & 333 \\
\hline SA & 381,059 & 127,274 & 0.1708 & 7,622 & 434 \\
\hline TAS & 283,886 & 143,078 & 0.1674 & 4,227 & 236 \\
\hline
\end{tabular}

Source: Authors' own calculations based on CoreLogic data.

The immediate impact of the reform could be limited further if the reduction in transfer duty occurred in smaller increments. To take New South Wales as an example again, a reduction in the transfer duty rate of 0.6 percentage points would require a recurrent property tax rate of 0.0317 and mean an annual recurrent property tax payment of $\$ 129$. Thus, the model does not lock states into a trajectory but allows for adaptation to behavioural responses and wider market conditions. This minimises the risk to government budgets and market stability. Nor does the model require governments to dispense with transfer duty entirely, noting that transfer duties can be useful when deployed selectively to dampen speculation in rapidly rising markets. More detailed modelling of a range of reform designs and scenarios is presented in the final report for Project C (see Eccleston, Warren et al. 2017). 
There are distributional consequences that arise in the transition to a recurrent property tax (such as double taxation, disadvantages to those who hold property for longer periods, or the need for existing land tax liabilities on investment properties to be folded into the new property tax). However, these can be managed through transitional and exemption strategies. For example, nationally coordinated deferral options could be used to mitigate the effect on asset-rich but income-poor households.

\subsection{Implications and recommendations}

Existing mechanisms for raising property tax revenue in Australia are fragmented, complicated, and inconsistently administered. State government budgets currently rely heavily on transfer duty, which is inefficient and volatile, while efficient, recurrent taxes on property values are only narrowly applied. Yet although there is a consensus on the technical aspects of reform, there is less agreement on how to negotiate the political economy of transition.

The approach recommended here is built on intergovernmental cooperation and harmonisation of valuation methods, property tax bases and data collection systems. This administrative backbone will determine the extent to which subsequent reforms can be successfully implemented. It will be strengthened by Australian Government commitment and involvement, including through the provision of incentives that encourage states and territories to act in a coordinated, strategic manner.

The recommended reforms are modelled on a revenue neutral basis. This avoids the political challenges of increasing non-property taxes or finding alternative sources of revenue to fund property tax reform. While technically feasible, a strategy requiring direct financial assistance from the Australian Government is less likely to succeed than an approach that individual state governments can implement unilaterally without detriment to their budgets.

The reforms themselves offer a simple, progressive framework to ensure most purchasers and lower value properties will pay less transfer duty than they do under current regimes. Within this framework, states can set rates and thresholds according to their local context, and adjust them as required in response to behavioural changes or market conditions. The framework also offers scope for governments to undertake a realistic, incremental transition from transfer duty to a broad-based recurrent property tax while containing the immediate distributional impacts.

Although it is a departure from orthodoxy, retaining transfer duty as a progressive and partial component within a wider property tax system in the short-to-medium term both positively contributes to wider housing affordability goals and reduces the fiscal strain associated with a full switch to a broad-based recurrent property tax. Additional housing-related benefits will be obtained from ensuring that aggregation provisions within the existing land tax system are abolished and that the new recurrent property tax system applies to non-aggregated values.

\subsubsection{Recommendations:}

State governments, with Australian Government cooperation, should immediately commence reform of the administrative foundations of the subnational property tax system and specifically, should develop: 
- a national register of property ownership and use

- a nationally consistent approach to property valuation

- further provisions for relevant interagency data-sharing

- integrated approaches to state and local government property tax collection.

In the short term, state governments should simplify their current transfer duty systems by introducing a single flat rate with a tax-free threshold set as a percentage of the median house price. Building on this foundation, states can then, in the medium term, adjust rates and thresholds as required for different categories of ownership and use.

In the longer term, state governments should implement transitional arrangements to phase up broad-based recurrent property taxes, with the proceeds diverted to phasing out and potentially abolishing transfer duties on immovable property. 


\section{$5 \quad$ Pathways to housing tax reform}

Australia's tax and transfer system makes a significant contribution to the shape and dynamics of the current housing system. Tax policy and practices at federal, state and local levels impact on housing and investment markets and have contributed to Australia's growing housing affordability problems. The reform pathway proposed in this report sets out pragmatic, realistic changes that can be made to tax policy design and settings. These changes, when implemented, will contribute to creating more sustainable and affordable housing market outcomes for all Australians.

\subsection{Designing the pathway}

Inquiry research question 1: What are the best integrated housing tax reform pathways that are financially sustainable, politically viable, and address tax-related distortions in Australian housing markets?

In the earlier chapters of this report we suggested changes to income tax, retirement savings and subnational property tax policy settings that could contribute to improving the fairness and equity of the housing market and have broader benefits for the Australian economy and society more generally. We also identified the political challenges in each area and suggested strategic approaches, including incremental implementation, to address these.

In this section, we integrate our recommendations into a coherent and coordinated reform pathway. The resulting agenda is set out in Figure 10 below.

- In the immediate to short-term, the focus is on establishing the foundations of reform. These will provide the basis upon which tax policy settings can be incrementally adjusted over time.

- Effective implementation requires a robust and efficient administrative regime (outlined in Chapter 4 specifically in relation to state-level taxation, but also applicable to other strands of reform). The regime would benefit from cooperation between state governments and leadership from the Australian Government, as well as input from local governments.

- Successful reform will require advocacy and communication that explains the benefits and implications of housing tax reform. This task is politically challenging as the partisan debate over housing tax policy during the most recent federal election campaign demonstrates.

- In the medium to long-term, specific reforms can be introduced, initially calibrated to have only modest effects. Although this means that results will not be immediately visible, it does minimise the shock of change for households, government budgets and the housing market. This is important because first, any adverse consequences are likely to disproportionately affect low-income and disadvantaged households with fewer resources to manage the effects and second, dramatic change is likely to undermine community support for reform. Once established and administratively embedded, policy settings such as caps, rates and thresholds can be progressively adjusted to achieve desired outcomes, such as greater neutrality, raising additional revenue to support housing policy goals or to drive behavioural 
change. The size of each adjustment is not fixed but can be altered as required in response to market conditions, unforeseen reactions or other external factors. 
Figure 10: An integrated reform pathway

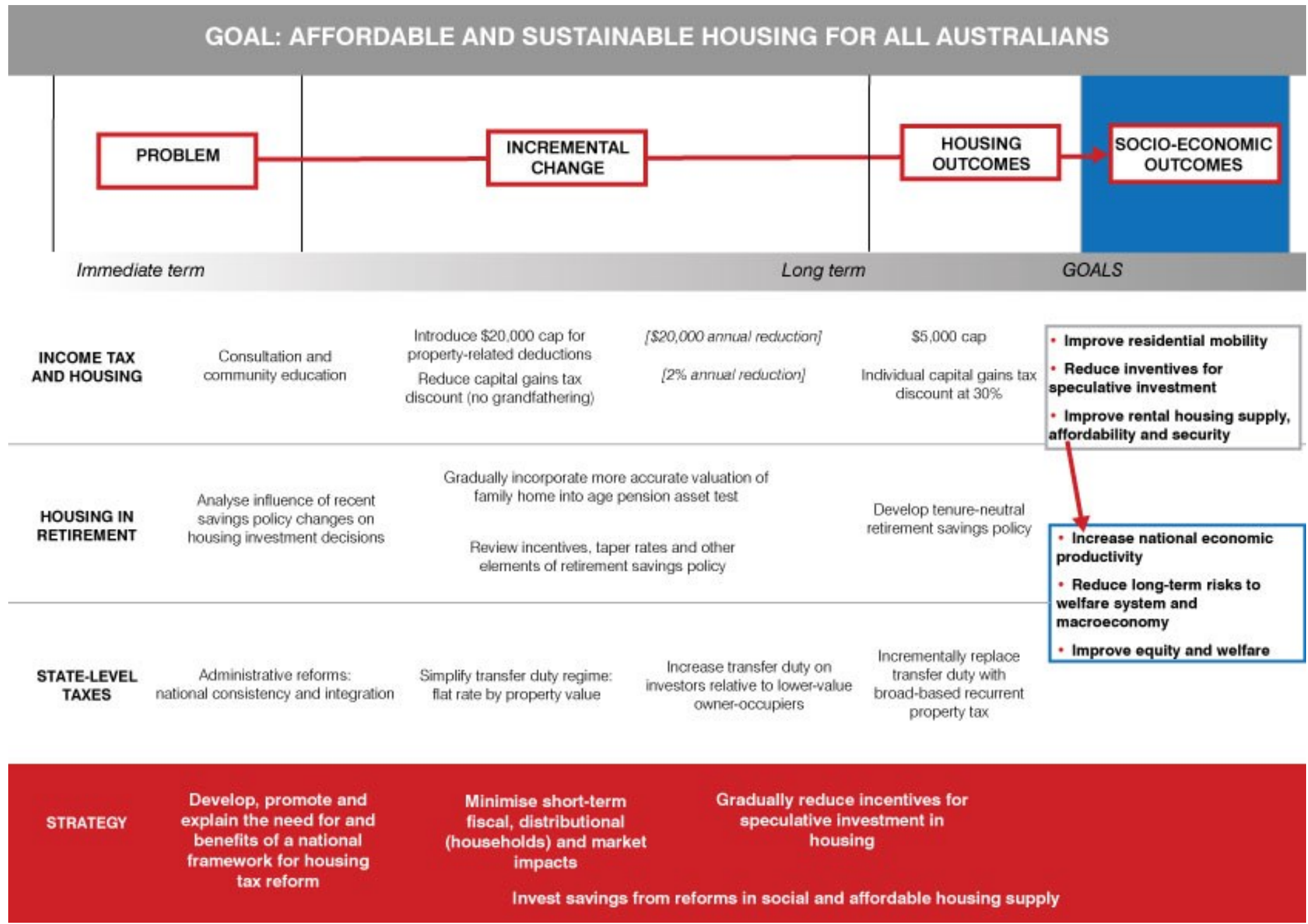

Source: Authors 
A further strategy that will both assist in managing the political economy challenges and contribute to meeting the housing policy and broader socio-economic goals identified in the framework is the hypothecation (or the earmarking of particular taxes for specific expenditures) of any revenue raised from the reforms into social and affordable housing provision. AHURI research has clearly and unequivocally demonstrated the value of investment in low-cost housing in terms of social cohesion, economic growth and labour market efficiency (Phibbs and Young 2005; Phibbs and Thompson 2011; Ong, Wood et. al. 2017). There is an active debate regarding the merits of hypothecation; proponents argue it strengthens the fiscal contract by drawing direct connections between taxes paid and services provided, while those opposed (traditionally policy makers) tend to argue that it limits budget flexibility and that taxpayer willingness to pay should not determine a governments' spending priorities (Mulgan and Murray 1993). While sympathetic to this critique, we believe a political commitment to spending additional revenue derived from phasing out tax concessions to support affordable housing will enhance the political appeal of such reforms.

In addition, we propose an incremental approach to reform in which governments commit to long-term reform objectives that are implemented incrementally over a 10 to 15 -year period. The advantage of this 'pathway' approach is that it minimises market disruption and distribution impacts in the short run while making a contribution to better housing outcomes over the longer term. We acknowledge that the approach is not without risks including the possibility that future governments might abolish or retrench reforms before they are fully implemented as was the case with the Carbon Reduction Emissions Scheme. However, on the balance of evidence (including the opinions of numerous stakeholders consulted during this project) the political viability of incremental reform is much better than a 'big bang' approach. Moreover, once contentious reforms which deliver long-term dividends are initiated then there are few political incentives to abolish them. This has been the experience with land tax reform in the ACT.

This strategy can be used to directly benefit particular cohorts, such as would be the case if revenue raised by a more accurate valuation of the family home in the aged pension asset test was reinvested in housing for people who are not able to retire as a home owner.

The problems in Australia's housing system identified in the first chapter of this report are felt most acutely by households on low incomes or living in insecure, unstable or unaffordable housing. These households would derive most direct benefit from affordable housing provision, but by removing pressure from the lower end of the market, there would be an indirect benefit for others competing in the private rental market or aspiring to enter home ownership. Increased investment in new, suitable and secure rental housing would also deliver benefits for the construction sector and the Australian economy more generally.

The pathway to housing tax reform presented in Figure 10 below contains specific policy settings and objectives that we believe are both feasible and desirable, but decisions on matters such as rates, thresholds and caps ultimately rest with the government of the day. What our pathway offers is a framework of policies that can be scaled up or down, depending on political considerations, market conditions or electoral sentiment, while being consistently seeking to reduce incentives to invest speculatively in residential property and provide greater capacity to households to choose and access housing options that suit their needs. 


\subsection{Directing the pathway}

Inquiry research question 2: What are the central goals of the housing tax reform agenda? Can tensions between the objectives of fiscal sustainability, economic efficiency and vertical and horizontal equity be managed?

The central goal of the agenda outlined in Figure 10 is to improve access to secure, suitable and affordable housing for all Australians. This broad goal is best achieved by reforming tax policy as it applies to housing to promote residential mobility, improve tenant security, and discourage short-term speculation while ensuring that the property taxes are distributed so that owners of higher value properties pay marginally more than those with fewer resources. Wherever possible housing tax reforms should also function to improve national economic efficiency. By pursuing these objectives, housing tax reform will make a significant contribution to the overarching goal of creating a more productive, sustainable and equitable housing system.

This report has provided a clear rationale for our reform proposals in terms of the housing outcomes we seek to achieve. We have not been able to include in our analysis detailed assessment of all possible impacts in other areas (see Section 5.4 below), but there are economic, social and budgetary dividends we would expect to see. Table 6 below summarises the housing dividends likely to result from reforms proposed in this report.

\subsubsection{Do these reforms work as an 'integrated package'?}

- There was not the scope in the analysis work of each empirical project related to this inquiry to model the cumulative impact of proposed reforms. However, all reforms in the program are designed around inbuilt mechanisms that mitigate against the possibility of adverse outcomes (e.g. minimal impact on government and household budgets, particularly those on low incomes) and allow for the close monitoring of, and adaptability to, unintended cumulative consequences or changing external conditions that might impact on reform outcomes (e.g. a coordinated and incremental approach).

- We have focused the key areas of integration in this Inquiry on addressing the economic and political factors that pose the greatest barriers to reform (for a description of these, see Section 5.3 below). For example, all reforms propose: incremental change to better manage shifts between old and new policy settings; the minimisation of economic risks, such as disruption to revenue flows both at state and household level; a high level of political feasibility; and a focus on improved social and distributive outcomes such as improved equity and fairness in housing. Table 6 highlights key areas of alignment across reforms.

- Each empirical project in this inquiry is designed to contain all elements necessary for successful reform implementation on its own merit. However, we believe that the cumulative impacts of implementing these as a package of reforms will benefit a range of outcomes in the long term. For example, we argue that a coordinated and long-term approach to housing tax reform led by our national and state governments-including the coordination of national policy goals such as the establishment of administrative foundations for reform-will enhance the capacity for these reforms to have a deeper positive impact in Australia into the future. 
Table 7: Summary of expected reform outcomes

\begin{tabular}{|c|c|c|c|c|c|}
\hline Outcome & What will reform achieve? & How will reform achieve it? & 2 & 3 & 4 \\
\hline \multirow[t]{8}{*}{ Housing } & \multirow{2}{*}{ Better match between housing and needs } & Reduction in incentive to over-capitalise and/or divert wealth into owner-occupied housing & & $\mathbf{x}$ & \\
\hline & & Reduction in transfer duty costs (supports mobility due to reduction in up-front cost of moving) & & & $\mathbf{x}$ \\
\hline & $\begin{array}{l}\text { Increased home ownership, especially for } \\
\text { younger }{ }^{16} \text { and less wealthy households }\end{array}$ & $\begin{array}{l}\text { Introduction of recurrent property tax (places downward pressure on house prices over time } \\
\text { leading to greater affordability) }\end{array}$ & & & $\mathbf{X}$ \\
\hline & $\begin{array}{l}\text { Reduced mortgage-related household debt } \\
\text { levels }\end{array}$ & Reduced competition from residential property investors due to reduced incentive for speculation & $\mathbf{x}$ & & \\
\hline & $\begin{array}{l}\text { More housing assistance for people on low } \\
\text { incomes or with other vulnerabilities }\end{array}$ & $\begin{array}{l}\text { Diversion of savings arising from housing tax reform into social and affordable housing } \\
\text { assistance }\end{array}$ & $\mathbf{x}$ & $\mathbf{x}$ & \\
\hline & \multirow{3}{*}{$\begin{array}{l}\text { A more secure, affordable and accessible } \\
\text { private rental market }\end{array}$} & Implementation timeframe minimises risk of short-term reactionary dis-investment & $\mathbf{x}$ & & $\mathbf{x}$ \\
\hline & & Reduction in incentive to invest for speculative capital gain leading to improved tenure security & $\mathbf{x}$ & & \\
\hline & & More level playing field to support institutional investment in affordable rental housing & $\mathbf{x}$ & & $\mathbf{X}$ \\
\hline \multirow[t]{5}{*}{ Economic } & Improved economic productivity & Reduction in transfer duty costs (supports mobility due to reduction in up-front cost of moving) & & & $\mathbf{x}$ \\
\hline & \multirow{2}{*}{ Reduced economic risks } & Reduced incentives for destabilising and over-leveraged speculative investment & $\mathbf{x}$ & & \\
\hline & & Restoration in home ownership rates to support 'asset-based welfare' model & $\mathbf{x}$ & $\mathbf{x}$ & $\mathbf{x}$ \\
\hline & \multirow{2}{*}{$\begin{array}{l}\text { Stable yet flexible tax policy framework into the } \\
\text { future }\end{array}$} & Building consensus and administrative foundations as the first step in reform agenda & $\mathbf{x}$ & $\mathbf{x}$ & $\mathbf{x}$ \\
\hline & & $\begin{array}{l}\text { Long-term, scalable reform pathway: clear and definite long-term objective, capacity to adapt to } \\
\text { external economic change }\end{array}$ & $\mathbf{x}$ & & $\mathbf{x}$ \\
\hline
\end{tabular}

${ }^{16}$ There is a debate among policy makers about whether younger Australian households place the same aspirational value on home ownership as previous generations. The research evidence indicates that the decline in home ownership replicates broader patterns of social and intergenerational inequality, suggesting that the decline is in large part the result of ongoing structural problems within the housing market and Australian society more broadly (e.g. Stebbing and Spies-Butcher 2016). 


\begin{tabular}{|c|c|c|c|c|c|}
\hline Outcome & What will reform achieve? & How will reform achieve it? & 2 & 3 & 4 \\
\hline \multirow[t]{2}{*}{ Budgetary } & Preserved or increased revenue & Reform design is revenue neutral (state reforms) or revenue positive (federal reforms) & $\mathbf{x}$ & $\mathbf{x}$ & $\mathbf{x}$ \\
\hline & Reduced long-term social and economic risk & $\begin{array}{l}\text { Reform design generates sustainable additional federal revenue that can be justifiably directed } \\
\text { into housing assistance (reduces risk to social security budgets and infrastructure) }\end{array}$ & $\mathbf{x}$ & & \\
\hline \multirow[t]{4}{*}{$\begin{array}{l}\text { Social and } \\
\text { distributive }\end{array}$} & \multirow{2}{*}{$\begin{array}{l}\text { Improved equity and fairness within housing } \\
\text { system: across income distribution and } \\
\text { intergenerationally }\end{array}$} & $\begin{array}{l}\text { Reduction in degree to which retirement savings and income tax policy settings favour high- } \\
\text { income, high-wealth and older, more established individuals over other households }\end{array}$ & & $\mathbf{x}$ & \\
\hline & & Increased access to home ownership for younger and lower income households & $\mathbf{x}$ & & $\mathbf{x}$ \\
\hline & \multirow{2}{*}{$\begin{array}{l}\text { Improved housing assistance for those on low } \\
\text { incomes or with other vulnerabilities }\end{array}$} & Increased investment in social and affordable housing supply & $\mathbf{x}$ & $\mathbf{x}$ & \\
\hline & & Reduction in short-term speculative investment (and therefore in incentive to limit tenure security) & $\mathbf{x}$ & & $\mathbf{x}$ \\
\hline
\end{tabular}




\subsection{Overcoming the barriers}

Inquiry research question 3: What are the major political and institutional barriers to housing tax reform? What policy design features and strategies can be used to mitigate these obstacles to reform?

One of the key tasks of this Inquiry has been to identify the factors undermining the capacity of politicians, policy makers, governments and stakeholders to implement meaningful reform. This is important because although current housing tax policy settings are a 'sensitive and longerterm affair' (Daley, Coates et al. 2018: 9, 67), we argue that good policy is worth pursuing regardless of the political challenges.

There are several specific debates that arise in relation to the political economy of housing tax policy change. These relate respectively to the distributive consequences of any reform to existing policy settings, the effect on the housing market, the effect on government budgets, and the complications introduced by federal-state financial relations.

\section{Distribution}

The primary barrier to gradually reducing the concessions applying home ownership and residential property investment is that housing is the main form of both national and household wealth in Australia; housing assets are worth $\$ 7$ trillion dollars and Australia has the highest per capita rate of property investment in the OECD, with over 2 million Australians owning investment properties. Given this exposure to the residential property market there are acute political sensitivities in relation to policy changes that may diminish the value of residential property or increase the cost of holding it.

\section{The market}

Related to distributional concerns is the fear that policy change could trigger rapid adjustments in home prices that may have subsequent implications for property owners, rental housing supply and consumers of housing services such as tenants (especially lowincome tenants who would have few resources with which to find alternative accommodation or cope with increases in rent).

\section{Revenue}

All levels of government and state governments in particular rely heavily on revenue from property taxes and there are genuine questions around their capacity to remain fiscally sustainable should this no longer be available.

\section{Federalism}

Under current federal-state arrangements, there is the risk that tax reform will have uneven distributional consequences across jurisdictions. For example, Australia's horizontal fiscal equalisation regime is not policy neutral and a unilateral decision by one state to broaden its property tax base to fund a reduction in transfer duty would likely result in a significant reduction in that state's GST share. 
To address these concerns, as well as the political barriers created by short-term political opportunism and sectional concerns, our strategy includes a broad set of practical policy design principles that address key barriers to reform and will increase the prospects for its successful implementation:

- Reforms should be directed at long-term outcomes, but the reform pathway should contain realistic and achievable objectives in the shorter to mediumterm.

- Reforms should be phased in over a period. Incremental reform has a number of key benefits:

- It will ensure that policy options that might otherwise be viewed as risky or unpalatable become more achievable because policy makers will have available the time needed for the strategic community education and engagement that will mitigate political or other resistance.

- Policy makers will have time to assess, understand and better incorporate the effect of any behavioural or distributional outcomes into the reform process as it moves forward-this is key to minimising market disruptions and impact concerns.

— It will provide budget certainty and enable ongoing budget flexibility in every changing economic circumstance.

- Reforms should be designed that are appropriate in terms of scale. This means setting broad reform strategies with in-built flexibility (e.g. as to rates and impacts) that allows policy makers to reflect and respond to the current policy context and minimise political disruption or adverse market consequences. A scalable system has the potential to expand (and, if necessary, contract) reforms to maximise reform agility and allow access to new reform functions with minimal effort or political cost.

- Reforms should be the product of both Australian Government leadership and coordination between state goverments. The Australian Government, for example, could encourage a coordinated response from states through the equitable redistribution windfalls from the efficiency dividends of tax reform. OECD research highlights the importance of national leadership to the success of tax reform (Blochliger and Vammalle 2012).

\subsubsection{Minimising distributional impacts}

Millions of Australian households have a direct financial interest in residential real estate either as owner occupiers or investors and, notwithstanding growing concerns about housing affordability, there is likely to be political resistance to abrupt policy changes that have a negative impact on property values or increase the costs of holding residential property.

Bearing these considerations in mind, this pathway to reform is designed to have a negligible short-term impact on housing markets with any increase in taxes largely falling on owners of properties of above-average value or wealthier, higher income investors. Even after a 10-15 year transition to a land tax the recurrent tax payment would be less than 1 per cent of median 
household income and comprehensive deferral provisions would be in place to ensure that lowincome asset-rich households are not unduly affected.

As noted above, an incremental and phased approach to reform that is scalable and flexible enough to respond to prevailing conditions will reduce the risk of short-term house price and rent increases. But in the longer term, it will also improve the fairness of the housing tax system, by protecting housing value and wealth for home owners while redistributing taxes to assist Australians currently locked out of the market and increasing the supply, affordability and security of private rental markets.

\subsubsection{Minimising market disruption}

For decades, Australia has sustained a policy framework specifically designed to encourage and support home ownership. Incentives have included CGT exemptions and discounts, the non-taxation of imputed rents and widespread concessions and exemptions for owner-occupied property, such as in the age pension asset test or state land tax regimes. These tax policies, and others encouraging investment in residential property, such as negative gearing, have supported high levels of owner-occupation but have also resulted in the increased demand for property investment as a wealth-building vehicle.

These policies are also enmeshed in deep and widely held cultural expectations that property ownership is a one-way ticket to prosperity. The promotion of residential property ownership has underpinned ongoing community, industry and political anxieties that winding back incentives to property owners will disrupt markets and result in a collapse in demand and prices and an increase in rents.

Our strategy provides a practical pathway that addresses these community and political anxieties. We have shown that there are politically expedient, fiscally sustainable and efficient ways to implement reform that will minimise disruption to the economy and housing markets, but also benefit the many Australians in need of more affordable, appropriate and secure housing, whether through home ownership or secure tenancies, but who are currently excluded from the 'Australian way'.

\subsubsection{Preserving state government revenue}

Especially in those states where house prices are high, transfer duty revenue makes a significant contribution to state government budgets (Mares 2017). It is also an important source of revenue within state control that can be used to fund essential human services, many of which, like health, transport or education, are coming under increasing pressure. Similarly, gradually reducing tax concessions on income derived from housing investments as described in Chapter 2 will improve the sustainability of the federal budget.

In Chapter 4, we outlined a simpler and fairer transfer duty regime that would result in no reduction in revenue. Taking a revenue neutral approach as a first principle in reform means that debate can focus on the delivery of 'good tax design' features including progressivity, equity and efficiency, rather than on how governments can or will recoup lost revenue or what additional taxes will cover the shortfall. Revenue neutrality can also be extended to consumers by designing transition strategies that change the timing of payments rather than their total amount (see Section 4.4.3). 


\subsubsection{Coordinating change across the federation}

There is genuine concern among state governments that unilateral tax reforms, especially at the subnational level, will result in any gains being distributed away from the reforming state. For example, as noted by the Productivity Commission (2017), states with higher property turnover rates such as Queensland currently receive a greater proportion of GST revenue from the Commonwealth Grants Commission, and so shifting to a broad-based recurrent tax that does not vary by turnover will result in a reduction in their GST share. This political risk acts as a barrier to individual states justifying what is already controversial reform.

For this reason, our pathway begins with reform to the administrative foundations of tax policy. Australian Government leadership will be required, both to advance data collection and standardisation protocols that will underpin the administrative framework, and to recognise and address barriers met by states in their implementation of reform. This will include putting policies in place to ensure all states benefit from reform dividends in the longer term.

For example, the efficiency gains to the Australian Government if states transition to a recurrent property tax (Eccleston, Woolley et al. 2013) could be directed to a program of incentives encouraging state governments to pursue reform. The Australian Government should also administer and underwrite deferral regimes to ensure that low-income, asset-rich households are not unduly affected by the introduction of a recurrent property tax or changes to the pension asset test. This strategy was central to the successful implementation of national competition policy in the early 1990s, while a more recent OECD study of successful subnational tax reforms also highlighted the importance of national leadership (Blochliger and Vammalle 2012).

\section{$5.4 \quad$ Limiting factors}

The pathway we have outlined provides a comprehensive strategy that integrates technically detailed modelling within a conceptual framework centred on the political economy of tax reform. It provides sufficient detail to enable governments and key stakeholders to develop more detailed proposals to implement its recommendations.

However, there are factors outside the scope of our analysis that we have not been able to account for. Tax, as we have noted, is only one factor in shaping housing outcomes, and there are other political, social, environmental or economic factors that might influence the way in which reform unfolds. Given these diverse external factors, it is inherently difficult to predict market or behavioural responses to tax changes and consequently much of the modelling presented here assumes no behavioural response in the data. Indeed, as the results in Chapter 3 demonstrate, household behaviour is not always rational.

Our agenda is therefore designed specifically around an incremental and progressive pathway to change. If there are problematic market or behavioural responses, then governments can respond by adjusting rates, caps and thresholds, or by slowing the pace of reform to allow for better communication with affected households. This flexible approach has been adopted with some success in the ACT as they transition from a regime based on land transfer duties toward one based on recurrent property tax. Including appropriate research and evaluation to identify behavioural effects that arise from reform, including at the intra-household level, will ensure that any adjustments are evidence-based rather than politically-reactive. 


\subsection{Concluding remarks}

More than forty years ago, Kenneth Asprey, the then Chair of the Asprey Taxation Review Committee, stated that the forthcoming report would produce a fairer, simpler and more efficient tax system in Australia. The approach adopted by the Committee explicitly recognised that technically precise proposals for immediate implementation would more than likely be politically untimely, because:
When a tax system becomes somewhat ossified and somewhat incoherent as has the Australian, and when rather sweeping reforms are under consideration...structural reforms will inevitably take some years to implement, rate changes should be made gradually as the circumstances of the day permit, and transitional problems of much intricacy should be solved at every point. A proper appreciation of the ultimate aims of what is being proposed requires a presentation that in the first place is in terms of general principles rather than legal or quantitative detail. Strategy comes before tactics (Asprey and Parsons, 1975, s.1.12).

Almost half a century later, this statement still resonates. It shares with this report the argument that any reform agenda must also address the political economy of tax design and implementation. That this political economy has functioned as a formidable and sometimes impenetrable barrier can be seen in the numerous strategic, thorough, and principled tax reform proposals since the Asprey review which have been discarded with their recommendations only partially, if at all, implemented.

This Inquiry report outlines not just principles for tax design that will improve the efficiency, equity and sustainability of future housing tax policy settings, but critically presents meaningful political pathways to achieving this outcome. Our reform agenda provides a clear set of achievable objectives for state and federal governments through incremental, phased, revenue neutral strategies that will achieve long-term structural reform of key housing tax policy settings in Australia. With this political economy perspective, it is possible to implement tax policy settings that can improve access to affordable, sustainable, appropriate and secure housing for all Australians so that in another four decades we will not find ourselves—still-held captive to an 'ossified and somewhat incoherent' tax system. For this, Australia needs a culture of strong political leadership willing to put the tax reform agenda, including its best principles, strategies and tactics, back on the table. 


\section{References}

ACT Government (2012) ACT taxation review, ACT Treasury, accessed 15 August 2017, http://www.treasury.act.gov.au/documents/ACT\%20Taxation\%20Review/ACT\%20Taxation \%20Review\%20May\%202012.pdf.

Actuaries Institute (2016) Unlocking housing wealth-options to meet retirement needs, Institute of Actuaries of Australia, Sydney.

Andrews, D., Sánchez, A.C. and Johansson, Å. (2011) Housing markets and structural policies in OECD countries, OECD Economics Department Working Paper No. 836, OECD Publishing, Paris.

Arnold, J.M., Bry, B., Heady, C., Johansson, Å., Schwellnus, C. and Vartia, L. (2011) 'Tax policy for economic recovery and growth', The Economic Journal, vol. 121, no. 550: F59-F80.

Asprey, K.W. and Parson, R.W. (1975) Taxation Review Committee: full report, Australian Government Publishing Service, Canberra, reproduced by the University of Sydney, accessed 11 December 2017, http://adc.library.usyd.edu.au/data-2/p00087.pdf.

Atalay, K., Whelan, S. and Yates, J. (2017) Housing prices, household debt and household consumption, AHURI Final Report No. 282, Australian Housing and Urban Research Institute, Melbourne, https://www.ahuri.edu.au/research/final-reports/282, doi:10.18408/ahuri-7307401.

Atkinson, M.E., Creedy, J. and Knox, D.M. (1995) 'Planning retirement income in Australia: routes through the maze', Australian Economic Review, vol. 28, no. 4: 15-28.

Australian Government (2015) Re:think: tax discussion paper, The Treasury, Accessed 15 August 2017, http://apo.org.au/node/53883.

Australian Council of Social Service (2015) 'Pension reform strikes the right balance, but Government wrong on super', ACOSS [media release], 23 June, accessed 19 December 2017, https://www.acoss.org.au/media release/new-report-to-reveal-extent-of-income-andwealth-inequality-in-australial.

Australian Council of Social Service, Community Housing Federation of Australia, Homelessness Australia, National Shelter and National Association for Tenants' Organisations (2015) An affordable housing reform agenda: goals and recommendations for reform, ACOSS, Redfern, NSW.

Australian Housing and Urban Research Institute (2017) 'How concerned are Australians about housing? Polls show housing and housing affordability is of rising concern for Australian households', AHURI, 28 September, accessed 19 December 2017, https://www.ahuri.edu.au/news-and-media/news/how-concerned-are-australians-abouthousing.

Beckett, J. (2014) Negative gearing—should we move towards the United Kingdom system? The Tax Institute, Sydney.

Bentley, P. and D'Cruz, M. (2016) A plan to end stamp duty: making property taxation fairer in New South Wales, The McKell Institute, Melbourne, accessed 15 August 2017, https://mckellinstitute.org.au/app/uploads/McKell Stamp Duty Land tax.pdf. 
Bird, R.M. and Scott Wilkie, J. (2013) 'Designing tax policy: constraints and objectives in an open economy', eJournal of Tax Research, vol. 11, no. 3: 284-320.

Blochliger, H. and Vammalle, C. (2012) 'Going beyond a zero-sum game: reforming fiscal relations', eJournal of Tax Research, vol. 10, no. 1: 49-64.

Blunden, H. (2016) 'Discourses around negative gearing of investment properties in Australia', Housing Studies, vol. 31, no. 3: 340-57.

Bourassa, S.C. and Yin, M. (2008) 'Tax deductions, tax credits and the homeownership rate of young urban adults in the United States', Urban Studies, vol. 45, nos 5-6: 1141-1161.

Brumby, J., Carter, B. and Greiner, N. (2012) GST Distribution Review: final report, Australian Government, Canberra.

Burke, T., Pinnegar, S., Phibbs, P., Neske, C., Gabriel, M., Ralston, L. and Ruming, K. (2007) Experiencing the housing affordability problem: blocked aspirations, trade-offs and financial hardships, AHURI Research Paper No. NRV3-9, Australian Housing and Urban Research Institute, Melbourne, https://www.ahuri.edu.au/ data/assets/pdf file/0016/2680/NRV3 Research Paper 9.pdf.

Carling, R. (2015) Right or rort? Dissecting Australia's tax concessions, Centre for Independent Studies, Sydney, accessed 19 December 2017, http://www.cis.org.au/app/uploads/2015/07/rr2.pdf?.

Cassells, R., Duncan, A., Kelly, S. and Ong, R. (2015), Beyond our means? Household savings and debt in Australia, Focus on the States Report Series No. 2, Bankwest Curtin Economics Centre, Perth, accessed 19 December 2017, https://espace.curtin.edu.au/bitstream/handle/20.500.11937/24190/227235 227235.pdf?se quence $=2$.

CEDA Balanced Budget Commission (2016) Deficit to balance: budget repair options, Committee for Economic Development of Australia, Melbourne, accessed 19 December 2017, http://www.ceda.com.au/CEDA/media/ResearchCatalogueDocuments/Research\%20and\% 20Policy/PDF/29966-CEDADeficittobalancebudgetrepairoptionsMarch2016.pdf.

Choice, National Shelter and National Association of Tenants' Organisations (2017) Unsettled: life in Australia's private rental market, Choice, National Shelter and NATO, accessed 19 December 2017, http://www.shelter.org.au/sites/natshelter/files/public/documents/The\%20Australian\%20Re ntal\%20Market\%20Report\%20Final\%20Web.pdf.

Cobb-Clark, D.A. and Hildebrand, V.A. (2011) 'Portfolio allocation in the face of a means-tested public pension', Review of Income and Wealth, vol. 57, no. 3: 536-560.

Commonwealth of Australia 2016, Budget measures 2016-17, Budget Paper No. 2, The Treasury, Canberra, accessed 18 December 2017, http://www.budget.gov.au/201617/content/bp2/download/BP2 consolidated.pdf.

Daley, J., McGannon, C., Savage, J. and Hunter, A. (2013) Balancing budgets: Tough choices we need, Grattan Institute, November 2013.

Daley, J. and Coates, B. (2015) Property taxes, Grattan Institute Working Paper No. 2015-5, Grattan Institute, Carlton, Vic., accessed 15 August, 2017, https://grattan.edu.au/wpcontent/uploads/2015/07/826-Property-Taxes.pdf. 
Daley, J., Coates, B. and Wiltshire, T. (2017) Submission to the National Housing Finance and Investment Corporation consultation paper, Grattan Institute, Carlton, Vic., accessed 19 December 2017, https://grattan.edu.au/wp-content/uploads/2017/10/Grattan-submissionto-NHFIC-20-October-2017-as-submitted.pdf.

Daley, J., Coates, B. and Wiltshire, T. (2018) Housing affordability: rebuilding the Australian dream, Grattan Institute, Carlton, Vic.

Daley, J., Wood, D. and Parsonage, H. (2016) Hot property: negative gearing and capital gains tax reform, Grattan Institute Report No. 2016-8, Grattan Institute, Carlton, Vic., accessed 23 October 2017, https://grattan.edu.au/wp-content/uploads/2016/04/872-Hot-Property.pdf.

Davidson, P. and Evans, R. (2015) Fuel on the fire: negative gearing, capital gains tax and housing affordability, Tax Talks No. 2, Australian Council of Social Service, Redfern, N.S.W., accessed 19 December 2017, http://www.acoss.org.au/images/uploads/Fuel on the fire.pdf.

Disney, J. (2006) 'Over our heads: housing costs and Australian families', Australian Quarterly, vol. 78, no. 2: 4-11.

Department of Human Services (2017) Assets, Australian Government, accessed 1 July 2017, https://www.humanservices.gov.au/customer/enablers/assets\#assetstestlimits

Dockery, A.M., Feeny, S., Hulse, K., Ong, R., Saugeres, L., Spong, H., Whelan, S. and Wood, G. (2008) Housing assistance and economic participation, AHURI Research Paper No. NRV1 Final, Australian Housing and Urban Research Institute, Melbourne, https://www.ahuri.edu.au/research/nrv-research-papers/nrv1-final.

DonaldsonWalsh Lawyers (2012) The state of state taxes: reform or land grab?, DWSpecial Report, Donaldson Walsh Lawyers, Adelaide.

Duncan, A.S., Hodgson, H., Minas, J., Ong-Viforj, R. and Seymour, R. (2018) The income tax treatment of housing assets: an assessment of proposed reform arrangements, AHURI Final Report No. 295, Australian Housing and Urban Research Institute, Melbourne, https://www.ahuri.edu.au/research/final-reports/295, doi: 10.18408/ahuri-8111101.

Eccleston, R., 2004. The thirty year problem: the politics of Australian tax reform, Australian Tax Research Foundation Research Studies, 206.

Eccleston, R. (2013) 'The tax reform agenda in Australia', Australian Journal of Public Administration, vol. 72, no. 2: 103-113.

Eccleston, R. and Smith, H. (2015) 'Fixing funding in the Australian federation: issues and options for state tax reform', Australian Journal of Public Administration, vol. 74, no. 4: 435-447.

Eccleston, R. and Marsh, I. (2011) 'The Henry tax review, cartel parties and the reform capacity of the Australian state', Australian Journal of Political Science, vol. 46, no. 3: 437-451.

Eccleston, R., Warren, N., Verdouw, J. and Flanagan, K. (2017) Pathways to state property tax reform, AHURI Final Report No. 291, Australian Housing and Urban Research Institute Limited, https://www.ahuri.edu.au/research/final-reports/291, doi:10.18408/ahuri-4111301.

Eccleston, R., Woolley, T. and Warren, N. (2013) 'Beyond the blame game: political strategies for state funding reform', Australian Journal of Public Administration, vol. 72, no. 1: 14-30. 
Eslake, S. (2013) Australian housing policy: 50 years of failure: submission to the Senate Economic References Committee, accessed 19 December 2017, http://www.sauleslake.com/australian-housing-policy-50-years-failure/\#sthash.k2R6IOwN.dpbs.

Eslake, S. (2015) 'Reforming the Australian taxation system: a principled approach', address to the Australian Financial Review's Tax Forum Summit, 22 September, Sydney, accessed 15 August 2017, http://www.saul-eslake.com/reforming-australian-taxation-system-principledapproach/ - sthash.5z7m4Amq.dpbs.

Eslake, S. (2017) No place like home: the impact of declining home ownership on retirement, Australian Institute of Superannuation Trustees, Melbourne.

Evans, C. (2011) 'Reflections on the Mirrlees Review: an Australasian perspective', Fiscal Studies, vol. 32, no. 3: 375-93.

Evans, C. and Krever, R. (2009) 'Tax reviews in Australia: a short primer', Australian Tax Review, vol. 38, no. 2: 69-75.

Evans, C., Minas, J. and Lim, Y. (2015) 'Taxing capital gains in Australia: an alternative way forward', Australian Tax Forum, vol. 30, no. 4, 735-761.

Finlay, R. (2012) 'The distribution of household wealth in Australia: evidence from the 2010 HILDA survey', RBA Bulletin, March: 19-27.

Government of South Australia (2015) State tax review: discussion paper, Department of Treasury and Finance, accessed 19 December 2017, https://s3-ap-southeast2.amazonaws.com/assets.yoursay.sa.gov.au/production/2015/03/11/23 4246998 State Tax Review Discussion Paper.pdf.

Government of Tasmania (2010) State tax review: discussion paper, Department of Treasury and Finance, accessed 15 August 2017, https://stors.tas.gov.au/au-7-0098-00316.

Grudnoff, M. (2015a) Top gears: how negative gearing and the capital gains tax discount benefit the top 10 per cent and drive up house prices, Policy Brief, The Australia Institute, Canberra, accessed 19 December 2017, http://www.tai.org.au/sites/defualt/files/Top\%20Gears\%20\%20How $\% 20$ Negative $\% 20$ Gearing $\% 20$ and $\% 20$ CGT $\% 20$ benefits $\% 20$ top $\% 2010 \% 20$ per $\% 2$ 0cent.pdf.

Grudnoff, M. (2015b) Who's getting negative? The benefits of negative gearing by federal electorate, Policy Brief, The Australia Institute, Canberra, accessed 19 December 2017, http://www.tai.org.au/sites/defualt/files/Negative\%20gearing\%20by\%20electorate\%20repor t.pdf.

Grudnoff, M. (2016) CGT main residence exemption: why removing the tax concession for homes over $\$ 2$ million is good for the budget, the economy and fairness, Policy Brief, The Australia Institute, Canberra, accessed 19 December 2017, http://www.tai.org.au/sites/defualt/files/TAl\%20\%20Capital\%20Gains \%20Tax\%20on\%20the\%20Primary\%20Residence.pdf.

Gurran, N. and Phibbs, P. (2016) 'How the Property Council is shaping the debate around negative gearing, taxes', The Conversation, 17 June, accessed 15 August 2017, https://theconversation.com/how-the-property-council-is-shaping-the-debatearoundnegative-gearing-taxes-61006. 
Harmer, J. (2009) Pension review report, Department of Families, Housing, Community Services and Indigenous Affairs, Canberra.

Headey, B., Marks, G. and Wooden, M. (2005) 'The structure and distribution of household wealth in Australia', Australian Economic Review, vol. 38, no. 2: 159-175.

Henry, K (2017) Australian business leaders must deliver a vision for the future, speech to the committee for economic development of Australia (CEDA), 22.02.2017. Accessed 1 May 2018, https://www.ceda.com.au/News-and-analysis/CEDA-Events/Australian-businessleaders-must-deliver-a-vision-for-the-future-Dr-Ken-Henry-AC.

Henry, K., Harmer, J., Piggot, J., Ridout, H. and Smith, G. (2009) Australia's future tax system: report to the Treasurer, Commonwealth of Australia, Canberra.

Hewson, J. (2014) 'The politics of tax reform in Australia', Asia \& the Pacific Policy Studies, vol. 1, no. 3: 590-599.

Hulse, K., Reynolds, M., Stone, W. and Yates, J. (2015) Shortage of affordable private rental housing increasing, AHURI Research and Policy Bulletin No. 195, Australian Housing and Urban Research Institute, Melbourne, https://www.ahuri.edu.au/research/research-andpolicy-bulletins/195.

Ingles, D. (2016) Taxes on land rent, Tax and Transfer Policy Institute working paper no. 6, accessed 15 August 2017, https:/taxpolicy.crawford.anu.edu.au/sites/default/files/publication/taxstudies crawford anu edu au/2016-11/taxes on land rent ingles final sep 2016.pdf.

IPART (Independent Pricing and Regulatory Tribunal) (2016) Review of the local government rating system: local government — draft report, accessed 19 December 2017, https://www.ipart.nsw.gov.au/files/sharedassets/website/shared-files/investigation-section9-legislative-review-of-the-local-government-rating-system/draft report review of the local government rating system - august 2016.pdf.

Jacobs, K. (2015) 'The "politics" of Australian housing: the role of lobbyists and their influence in shaping policy', Housing Studies, vol. 30, no. 5: 694-710.

James, A., Rowley, S., Cassells, R., Duncan, A. and Ong, R. (2015), Submission to the Standing Committee on Economics home ownership inquiry, AHURI Curtin Research Centre and Bankwest Curtin Economics Centre, accessed 19 December 2017, https://www.aph.gov.au/DocumentStore. ashx?id=257bc7fd-0eff-45f4-95429406967f2d2a\&subld=353233.

Johnston, C. (2016) Land tax: questions about reform, Shelter NSW, Sydney, accessed 15 August 2017, https://shelternsw.org.au/sites/shelternsw.org.au/files/public/documents/rpt1601landtaxupdate shelternsw.pdf.

Judd, B., Liu, E., Easthope, H. and Bridge, C. (2014) 'Downsizers and other movers: the housing options, choices and dilemmas of older Australians', in H. Caltenco, P-O Hedvall, A. Larsson, Rassmus-Gröhn and B. Rydeman (eds), Universal Design 2014: Three days of creativity and diversity: Proceedings of the International Conference on Universal Design, IOS Press, Amsterdam: 129-138.

Kelly, J-F., Hunter, J., Harrison, C., and Donegan, P. (2013) Renovating housing policy, Grattan Institute Report No. 2013-12, Grattan Institute, Carlton, Vic., accessed 15 August 2017, https://grattan.edu.au/wp-content/uploads/2014/03/800 Renovating Housing.pdf. 
Khoury, P. (2015) 'Neoliberalism, auditing, austerity and the demise of social justice', Social Alternatives, vol. 34, no. 3: 25-33.

KPMG (2015) Tax reform: A national challenge... join the conversation, KPMG, Sydney.

Lambert, M. (2011) NSW financial audit 2011, NSW Treasury, Sydney, accessed 19 December 2017, https://www.treasury.nsw.gov.au/sites/default/files/201703/NSW Financial Audit Report Part 2011- Full pdf.pdf.

Lowe, P. 2017, 'Household debt, house prices and resilience', address to Economic Society of Australia (QLD) business lunch, 4 May, Brisbane, accessed 11 December 2017, https://www.rba.gov.au/speeches/2017/sp-gov-2017-05-04.html.

Mangioni, V. (2015) Land Tax in Australia: Fiscal Reform of Sub-national Government, Routledge, Abingdon, U.K.

Mangioni, V. (2016) 'De-siloing and defining recurrent land tax revenue in Australia', Australasian Journal of Regional Studies, vol. 22, no. 1: 58-78.

Mangioni, V. and Warren, N. (2014) 'Re-defining the land tax base in highly urbanised locations', Australian Tax Forum, vol. 29: 455-476.

Mares, P. (2017) 'Housing taxes: getting from here to there', Inside Story, 4 December, accessed 19 December 2017, http://insidestory.org.au/housing-taxes-getting-from-here-totherel.

Marriott, L. (2010) 'Power and ideas: the development of retirement savings taxation in Australasia', Critical Perspectives on Taxation, vol. 21, no. 7: 597-610.

Minas, J. and Lim, Y. (2013) 'Taxing capital gains-views from Australia, Canada and the United States', eJournal of Tax Research, vol. 11, no. 2: 191-215.

Mortensen, J.L. and Seabrooke, L. (2008) 'Housing as social right or means to wealth? The politics of property booms in Australia and Denmark', Comparative European Politics, vol. 6, no. 3: 305-324.

Mulgan, G. and Murray, R. (1993) Reconnecting Taxation, Demos, London.

Murray, C. (2016) The first interval: evaluating ACTs's land value tax transition, Full report for Prosper Australia, accessed 01.05.2018 at https://www.prosper.org.au/wpcontent/uploads/2016/09/The-First-interval-Evaluating-ACTs-Land-Valur-TaxTransition.pdf.

National Housing Supply Council (2010) Second State of Supply report, Department of Families, Housing, Community Services and Indigenous Affairs, Canberra.

National Shelter (2015) National Shelter response to the tax discussion paper, National Shelter, Brisbane, accessed 19 December 2017, https://cdn.tspace.gov.au/uploads/sites/52/2015/06/National Shelter.docx.

Nooregaard, J. (2013) Taxing immovable property: revenue potential and implementation challenges, IMF Working Paper WP/13/129, International Monetary Fund, accessed 19 December 2017, https://www.imf.org/external/pubs/ft/wp/2013/wp13129.pdf. 
NSW Business Chamber and NSW Council of Social Service (2016) Taking on tax: reforming NSW property taxes, NSW Business Chamber, accessed 15 August 2017, https://www.nswbusinesschamber.com.au/NSWBCWebsite/media/Policy/Thinking Business Reports/FINAL-NSWBC-NCOSS-Taking-on-Tax-Report.pdf.

O’Donnell, J. (2005) 'Quarantining interest deductions for negatively geared rental property investments', eJournal of Tax Research, vol. 3, no. 1: 63-113.

Oliver, S. (2015) 'Tax concessions and tax reform in Australia', AMP Capital, accessed 19 December 2017, http://www.ampcapital.com.au/article-detail?alias=/olivers-insights/june2015/tax-concessions-and-tax-reform-in-australia.

Olson, M. (1965) The Logic of Collective Action: Public Goods and the Theory of Groups, Harvard University Press, Cambridge.

Ong, R., Wood, G., Whelan, S., Cigdem, M., Atalay, K. and Dodson, J. (2017) Inquiry into housing policies, labour force participation and economic growth, AHURI Final Report No. 285, Australian Housing and Urban Research Institute, Melbourne, https://www.ahuri.edu.au/research/final-reports/285, doi:10.18408/ahuri-8107001.

Pape, S. (2016) 'Home truths emerge on buying property and negative gearing', Herald Sun, 14 May, accessed 19 December 2017, http://www.heraldsun.com.au/business/barefootinvestor/home-truths-emerge-on-buying-property-and-negative-gearing/newsstory/f9ff42c7f43b005ed94c5e5576b92144.

Passant, J. (2014) 'Neoliberalism in Australia and the Henry Tax Review', Journal of the Australasian Tax Teachers Association, vol. 8, no. 1: 117-140.

Peters, P.G. (1991) The Politics of Taxation: A Comparative Perspective, Basil Blackwell, Oxford.

Phibbs, P. and Thompson, S. (2011) The health impacts of housing: toward a policy-relevant research agenda, AHURI Final Report No. 173, Australian Housing and Urban Research Institute Limited, https://www. ahuri.edu.au/research/final-reports/173.

Phibbs, P. and Young, P. (2005) Housing assistance and non-shelter outcomes, AHURI Final Report No. 74, Australian Housing and Urban Research Institute Limited, Melbourne, https://www.ahuri.edu.au/research/final-reports/74.

Phillips, K. (ed.) (2016) 'Transcript: tax and tax reform in Australia', Rear Vision, Radio National, 14 February, accessed 19 December 2017, http://www.abc.net.au/radionational/programs/rearvision/tax-and-tax-reform-inaustralia/7150188.

Polsky, A. (2000) 'When business speaks: political entrepreneurship, discourse and mobilization in American partisan regimes', Journal of Theoretical Politics, vol. 12, no. 4: 455-476.

Poterba, J.M., Venti, S.F. and Wise, D.A. (1996) 'How retirement saving programs increase savings', Journal of Economic Perspectives, vol. 10, no. 4: 91-112.

Power, E.R. (2017) 'Housing, home ownership and the governance of ageing', The Geographical Journal, vol. 183, no. 3: 233-246.

PricewaterhouseCoopers (2016) Tax reform: informing the debate: what are the implications of changing housing tax benefits?, PricewaterhouseCoopers, Sydney. 
Productivity Commission (2004), First home ownership, Inquiry Report No. 28, Productivity Commission, Melbourne.

Productivity Commission (2015) Housing decisions of older Australians, Research Paper, Productivity Commission, Canberra.

Productivity Commission (2017) Horizontal fiscal equalisation, Draft Report, Productivity Commission, Canberra.

Property Council of Australia, ACIL Allen Consulting (2015) Modernising Australia's tax system, Property Council of Australia, accessed 15 August 2017, http://admin.Iplc.com.au/projects/construction-and-property-industry/modernisingaustralias-tax-system.

Queensland Treasury (2015) Review of state finances, Queensland Treasury, accessed 19 December 2017, https://s3.treasury.qld.gov.au/files/review-of-state-finances.pdf.

Quiggin, J. (2015) Negative gearing, John Quiggin (webpage), accessed 24 April 2016, http://johnquiggin.com/2015/04/24/negative-gearing/.

Real Estate Institute of South Australia and Real Estate Institute of Australia (2015) REISA and REIA response to the South Australian State Tax Review Discussion Paper, accessed 15 August 2017, http://assets.yoursay.sa.gov.au/static/tax review/REISA\%20and\%20REIA.pdf.

Reserve Bank of Australia (RBA) (2017) Bulletin, Publications Committee, March 2017, accessed 20 March 2018, https://www.rba.gov.au/publications/bulletin/2017/mar/pdf/bu0317-reserve-bank-bulletin.pdf.

Rowley, S. and Ong, R. (2012) Housing affordability, housing stress and household wellbeing in Australia, AHURI Final Report No.192, Australian Housing and Urban Research Institute, Melbourne, https://www.ahuri.edu.au/research/final-reports/192.

Rowley, S., Leishman, C., Baker, E., Bentley, R. and Lester, L. (2017) Modelling housing need in Australia to 2025, AHURI Final Report No. 287, Australian Housing and Urban Research Institute, Melbourne, https://www.ahuri.edu.au/research/final-reports/287, doi:10.18408/ahuri-8106901.

Sandford, C.T. (1993) Successful Tax Reform: Lessons from an Analysis of Tax Reform in Six Countries, Fiscal Publications, Bath, England.

Senate Economics References Committee (2015) Out of reach? the Australian housing affordability challenge, accessed 19 December 2017, https://www.aph.gov.au/Parliamentary Business/Committees/Senate/Economics/Affordabl e housing 2013/ /media/Committees/economics ctte/Affordable housing 2013/report.pdf

Shapiro, J. (2017) 'Housing risks will force bank capital higher: APRA', Australian Financial Review, 5 April, accessed 11 December 2017, http://www.afr.com/business/banking-andfinance/financial-services/housing-risks-will-force-bank-capital-higher-apra-20170404grdomj.

Sharam, A., Ralston, L. and Parkinson, S. (2016) Security in retirement: the impact of housing and key critical life events, Swinburne University of Technology, Melbourne, accessed 19 December 2017, https://researchbank.swinburne.edu.au/file/bea2ad60-2914-452e-85f4d93ff9e6a323/1/PDF\%20\%28Published\%20version\%29.pdf. 
Slack, E. and Bird, R.M. (2015) How to reform the property tax: lessons from around the world, IMFG Papers on Municipal Finance and Governance No. 21, Institute on Municipal Finance and Governance, accessed 15 August 2017, http://munkschool.utoronto.ca/imfg/uploads/325/1689 imfg no.21 online final.pdf.

Smith, S. (2009) AHURI research agenda: Looking forward, Australian Housing and Urban Research Institute Limited, Melbourne.

Smith, G. (2012) 'The way forward on state tax reform: an AFTSR perspective', eJournal of Tax Research, vol. 10, no. 1: 126-37.

Soos, P. (2012) Written off: negative gearing, Prosper Australia, Melbourne, accessed 19 December 2017, http://www.prosper.org.au/wpcontent/uploads/2012/09/Philip Soos Written Off Negative Gearing.pdf.

Spies-Butcher, B. and Stebbing, A. (2011) 'Population ageing and tax reform in a dual welfare state', Economic and Labour Relations Review, vol. 22, no. 3: 45-63.

Stebbing, A. and Spies-Butcher, B. (2016), 'The decline of a homeowning society? Asset-based welfare, retirement and intergenerational equity in Australia', Housing Studies, vol. 31, no. 2: 190-207.

Stilwell, F. (2004) Submission to the Productivity Commission inquiry into first home ownership, University of Sydney, Sydney, accessed 19 December 2017, https://www.pc.gov.au/inquiries/completed/first-homeownership/submissions/sub212/sub212.pdf.

Treasury c. 2016, 'Superannuation reforms', Australian Government, accessed 14 December 2017, https://treasury.gov.au/superannuation-reforms/.

Turnbull, M. (2016), 'Transcript: doorstop interview with Treasurer, Penshurst, Sydney, 24 April', Malcolm Turnbull (webpage), accessed 13 December 2017, https://www.malcolmturnbull.com.au/media/doorstop-with-treasurer-penshurst-sydney.

Urban Development Institute of Australia (2015) Submission to the federal tax discussion paper, UDIA, Campbell, A.C.T., accessed 19 December 2017, https://cdn.tspace.gov.au/uploads/sites/52/2015/06/Urban-Development-Institute-ofAustralia.pdf.

Warren, N. (2010) 'The Henry review, state taxation and the federation', Australian Economic Review, vol. 43, no. 4: 409-421.

Whelan, S., Atalay, K., Dynan, L. (2018) Asset portfolio retirement decisions: the role of the tax and transfer system, AHURI Final Report No. 298, Australian Housing and Urban Research Institute Limited, Melbourne.

Whiteford, P. (2010) 'The Australian tax-transfer system: architecture and outcomes', Economic Record, vol. 86, no. 275: 528-544.

Wood, G. and Tu, Y. (2004) 'Are there clientele groups among investors in rental housing?', Real Estate Economics, vol. 32, no. 2: 413-36.

Wood, G., Ong, R. and Cigdem, M. (2014) Housing affordability dynamics: new insights from the last decade, AHURI Final Report No. 233, Australian Housing and Urban Research Institute, Melbourne, accessed 15 August 2017, https://www.ahuri.edu.au/research/finalreports $/ 233$. 
Wood, G., Ong, R. and McMurray, C. (2011) The impacts of the Henry Review recommendations on the private rental market-savings income discount and rent assistance, AHURI Final Report No. 175, Australian Housing and Urban Research Institute, Melbourne, https://www.ahuri.edu.au/research/final-reports/175.

Wood, G., Ong, R. and Stewart, M. (2010) 'Housing and tax policy: housing taxes and the supply of private rental housing', in M. Stewart (ed.), Housing and tax policy, Australian Tax Research Foundation, Sydney: 219-240.

Wood, G., Stewart, M. and Ong, R. (2010) Housing taxation and transfers: research study for the review of Australia's future tax system, accessed 19 December 2017, http://taxreview.treasury.gov.au/content/html/commissioned work/downloads/wood stewar $\underline{\mathrm{t} \text { and ong.pdf. }}$

Wood, G. and Winter, I. (2012) 'Scrapping stamp duties for a land tax', Insight, no. 6: 24-26.

Worthington, A.C. (2012) 'The quarter-century record on housing affordability, affordability drivers, and government policy responses in Australia', International Journal of Housing Markets and Analysis, vol. 5, no. 3: 235-52.

Wulff, M., Reynolds, M., Arunachalam, D., Hulse, K. and Yates, J. (2011) Australia's private rental market: the supply of, and demand for, affordable dwellings, AHURI Final Report No. 168, Australian Housing and Urban Research Institute, Melbourne, https://www.ahuri.edu.au/research/final-reports/168.

Yates, J. (2008) 'Australia's housing affordability crisis', Australian Economic Review, vol. 41, no. 2: $200-214$.

Yates, J. (2011) 'Housing in Australia in the 2000s: on the agenda too late?', in H. Gerard and J. Kearns (eds), The Australian Economy in the 2000s: Proceedings of a Conference, Reserve Bank of Australia, Sydney: 261-296.

Yates, J. (2012) 'Housing and distribution of wealth', 2012 Giblin Lecture, University of Tasmania, Hobart, 18 October, accessed 19 December 2017, http://sydney.edu.au/arts/economics/downloads/documents/pdf/Yates-2012-Giblinlecture.pdf.

Yates, J. (2016) 'Why does Australia have an affordable housing problem and what can be done about it?', Australian Economic Review, vol. 49, no. 3: 328-39.

Yates, J. and Bradbury, B. (2010) 'Home ownership as a (crumbling) fourth pillar of social insurance in Australia', Journal of Housing and the Built Environment, vol. 25, no. 2: 193211.

Yates, J. and Gabriel, M. (2006) Housing affordability in Australia, AHURI Research Paper No. NRV3-3, Australian Housing and Urban Research Institute, Melbourne, https://www.ahuri.edu.au/research/nrv-research-papers/nrv3-3.

Yates, J., Milligan, M., Berry, M., Burke, T., Gabriel, M., Phibbs, P., Pinnegar, S. and Randolph, B. (2007) Housing affordability: a 21st century problem, AHURI Final Report No.105, Australian Housing and Urban Research Institute, Melbourne, https://www.ahuri.edu.au/research/final-reports/105. 


\section{Appendix}

Table 8: Summary of major party policy announcements in the lead-up to the 2016 federal election

\begin{tabular}{|c|c|c|c|}
\hline \multirow{2}{*}{ Party } & \multicolumn{3}{|c|}{ Summary of policy announcements } \\
\hline & Housing investment & State taxation & Retirement savings \\
\hline ALP & $\begin{array}{l}13 \text { February 2016: Limit } \\
\text { negative gearing to new } \\
\text { housing from } 1 \text { July } 2017 \\
\text { Investments made prior } \\
\text { to this date fully } \\
\text { grandfathered } \\
\text { Halve capital gains } \\
\text { discount on assets } \\
\text { (excluding } \\
\text { superannuation fund } \\
\text { investments and small } \\
\text { business assets) } \\
\text { purchased after } 1 \text { July } \\
2017 \text { (i.e. reduce to } 25 \% \text { ) }\end{array}$ & $\begin{array}{l}\text { No stated federal policy } \\
\text { position but some public } \\
\text { statements indicate } \\
\text { general support for state } \\
\text { tax reform including } \\
\text { replacing stamp duty with } \\
\text { land tax }\end{array}$ & $\begin{array}{l}\text { Reduce tax-free } \\
\text { concession for people on } \\
\text { super income streams of } \\
\text { more than } \$ 75,000 \\
\text { Reduce higher income } \\
\text { superannuation charge } \\
\text { threshold }\end{array}$ \\
\hline Coalition & $\begin{array}{l}\text { Public statements } \\
\text { indicate support for } \\
\text { status quo }\end{array}$ & $\begin{array}{l}\text { No stated federal policy } \\
\text { position but some public } \\
\text { statements indicate } \\
\text { general support for state } \\
\text { tax reform including } \\
\text { replacing stamp duty with } \\
\text { land tax }\end{array}$ & $\begin{array}{l}3 \text { May 2016: Extend } 30 \% \\
\text { concessional } \\
\text { contributions tax to those } \\
\text { on incomes over } \\
\$ 250,000 \text {, reduce caps } \\
\text { on transfer balances and } \\
\text { annual concessional } \\
\text { contributions and } \\
\text { establish cap on lifetime } \\
\text { non-concessional } \\
\text { contributions } \\
\text { Introduce low-income } \\
\text { superannuation tax offset } \\
\text { on } 1 \text { July } 2017\end{array}$ \\
\hline Greens & $\begin{array}{l}\text { June } 2016 \text { (update of } \\
\text { existing policy): Abolition } \\
\text { of negative gearing for all } \\
\text { non-business assets } \\
\text { purchased on or after } 1 \\
\text { July } 2016 \\
\text { Investments made prior } \\
\text { to this date fully } \\
\text { grandfathered } \\
\text { Phase out capital gains } \\
\text { tax discount for trusts } \\
\text { and individuals by } 10 \% \text { a } \\
\text { year between } 1 \text { July } 2016 \\
\text { and } 1 \text { July } 2020\end{array}$ & $\begin{array}{l}\text { No stated federal policy } \\
\text { position but state tax } \\
\text { reform including } \\
\text { replacing stamp duty with } \\
\text { land tax is state party } \\
\text { policy in some } \\
\text { jurisdictions }\end{array}$ & $\begin{array}{l}\text { c. June 2016: Introduce } \\
\text { progressive } \\
\text { superannuation } \\
\text { contributions tax rates } \\
\text { (beginning at } 0 \text { and rising } \\
\text { to } 32 \text { cents in the dollar } \\
\text { for incomes over } \\
\$ 150,000 \text { ) }\end{array}$ \\
\hline
\end{tabular}

Source: Authors. 


\section{AHURI Research Centres}

AHURI Research Centre-Curtin University

AHURI Research Centre-RMIT University

AHURI Research Centre-Swinburne University of Technology

AHURI Research Centre-The University of Adelaide

AHURI Research Centre-The University of New South Wales

AHURI Research Centre-The University of South Australia

AHURI Research Centre-The University of Sydney

AHURI Research Centre-University of Tasmania

\section{Australian Housing and Urban Research Institute}

Level 1

114 Flinders Street

Melbourne Victoria 3000

T +61396602300

E information@ahuri.edu.au

ahuri.edu.au

ACN 090448918

twitter.com/AHURI_Research

f facebook.com/AHURI.AUS

in evid.in/AHURI_Linkedln 